\title{
Applications of Lysozyme, an Innate Immune Defense Factor, as an Alternative Antibiotic
}

\author{
Patrizia Ferraboschi ${ }^{1}\left(\mathbb{D}\right.$, Samuele Ciceri ${ }^{2} \mathbb{D}$ and Paride Grisenti ${ }^{3, *}$ \\ 1 Department of Medical Biotechnology and Translational Medicine, University of Milan, Via C. Saldini 50, \\ 20133 Milano, Italy; patrizia.ferraboschi@unimi.it \\ 2 Department of Pharmaceutical Sciences, University of Milan, Via L. Mangiagalli 25, 20133 Milano, Italy; \\ samuele.ciceri@unimi.it \\ 3 Bioseutica BV, Corso Elvezia 4, 6900 Lugano, Switzerland \\ * Correspondence: pgrisenti@bioseutica.com
}

Citation: Ferraboschi, P.; Ciceri, S.; Grisenti, P. Applications of Lysozyme, an Innate Immune Defense Factor, as an Alternative Antibiotic. Antibiotics 2021, 10, 1534. https://doi.org/ 10.3390/antibiotics10121534

Academic Editor: Maria

Stefania Sinicropi

Received: 26 October 2021

Accepted: 8 December 2021

Published: 14 December 2021

Publisher's Note: MDPI stays neutral with regard to jurisdictional claims in published maps and institutional affiliations.

Copyright: (c) 2021 by the authors. Licensee MDPI, Basel, Switzerland. This article is an open access article distributed under the terms and conditions of the Creative Commons Attribution (CC BY) license (https:// creativecommons.org/licenses/by/ $4.0 /)$.
Abstract: Lysozyme is a $\sim 14 \mathrm{kDa}$ protein present in many mucosal secretions (tears, saliva, and mucus) and tissues of animals and plants, and plays an important role in the innate immunity, providing protection against bacteria, viruses, and fungi. Three main different types of lysozymes are known: the c-type (chicken or conventional type), the g-type (goose type), and the i-type (invertebrate type). It has long been the subject of several applications due to its antimicrobial properties. The problem of antibiotic resistance has stimulated the search for new molecules or new applications of known compounds. The use of lysozyme as an alternative antibiotic is the subject of this review, which covers the results published over the past two decades. This review is focused on the applications of lysozyme in medicine, (the treatment of infectious diseases, wound healing, and anti-biofilm), veterinary, feed, food preservation, and crop protection. It is available from a wide range of sources, in addition to the well-known chicken egg white, and its synergism with other compounds, endowed with antimicrobial activity, are also summarized. An overview of the modified lysozyme applications is provided in the form of tables.

Keywords: innate immunity; peptidoglycan; Gram-positive; Gram-negative; antimicrobial; muramidase; lysozyme

\section{Introduction}

Lysozyme (or muramidase or N-acetylmuramic acid hydrolase E.C. 3.2.1.17) is a protein that exerts its enzymatic activity through the hydrolysis of the $\beta-1,4$-glycosidic bonds between $\mathrm{N}$-acetylmuramic acid (NAM) and N-acetylglucosamide (NAG) in the polysaccharide backbone of the peptidoglycans of the Gram-positive bacterial cell wall.

Peptidoglycan is composed of polysaccharide chains cross-linked by short peptides. The polysaccharide chains contain alternate units of NAM and NAG.

The peptides are bound to the lactate moiety of NAM and usually consist of L-alanine, D-isoglutamic acid (D-isoglutamine in many Gram-positive bacteria), L-lysine or mesodiamino pimelic acid (in Gram-positive and Gram-negative bacteria, respectively), and two D-alanine residues. The side chain peptides of different polysaccharide chains are linked together with a direct link between meso-pimelic acid and the first D-alanine (Gramnegative), or through a cross-bridge (Gram-positive), a peptide that is characteristic of each species (Figure 1) [1].

Due to its capacity to disrupt the bacterial cell wall, lysozyme has been considered as an endogenous antibiotic, innately essential in the defense against microbes since its discovery by A. Fleming in 1921 [2]. Lysozyme is a small, monomeric protein stabilized by four disulfide linkages among the eight cysteine residues of its chain (Figure 2). 

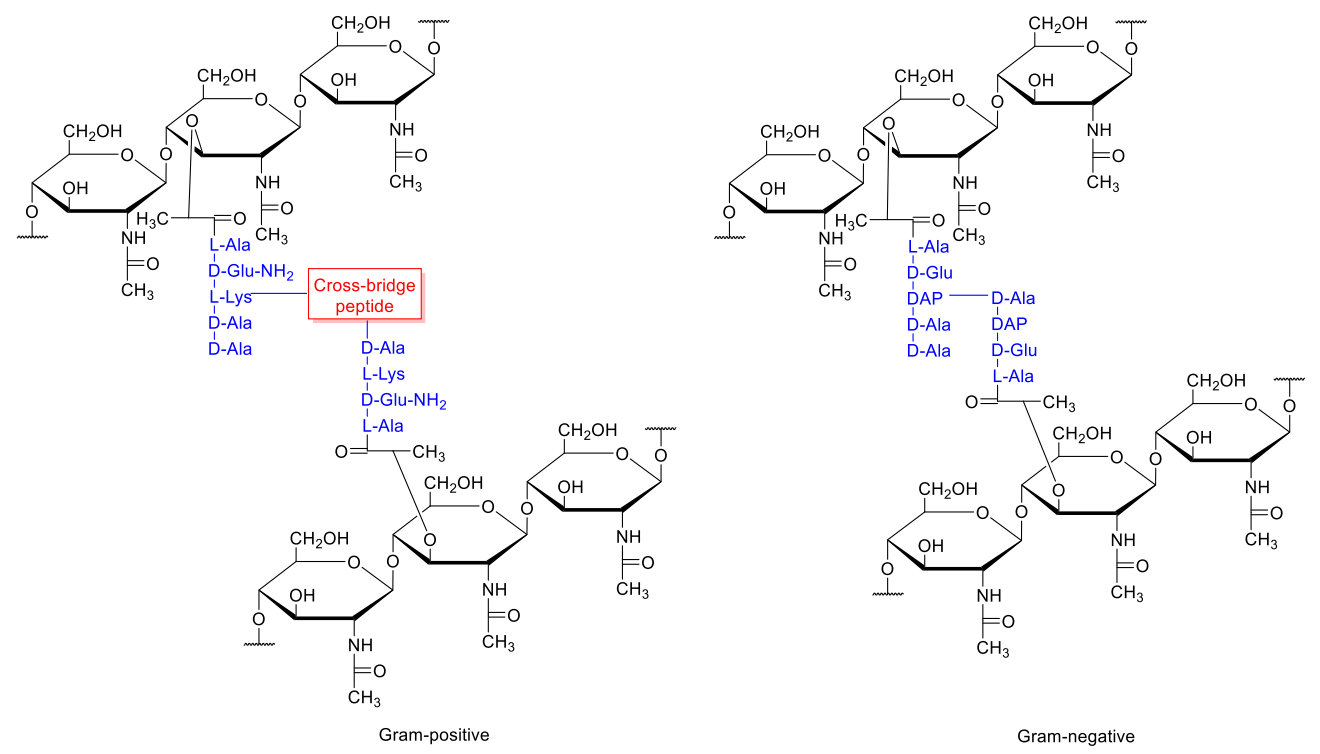

Figure 1. Peptidoglycan composition.

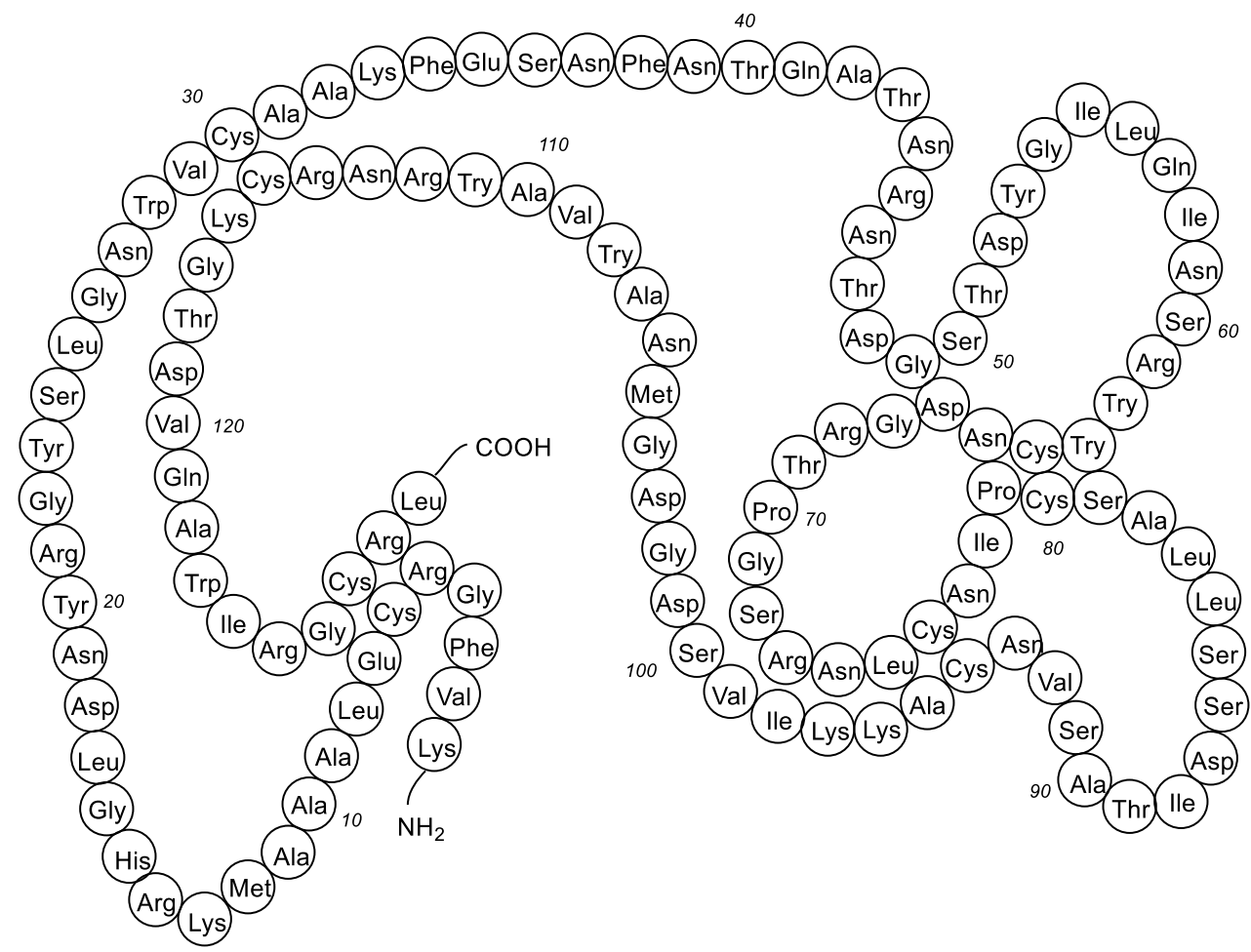

Figure 2. Structure of lysozyme (T. Wu et al. Food Chemistry 2019, 274, 698-709).

Lysozymes are present not only in human organs, tissues, and secretion, but also in the organs and secretions of various vertebrates, invertebrates, bacteria, and plants. They are classified into three main families: chicken type (c-type), goose type (g-type) and invertebrate type (i-type) [3]; also known are the phage type, bacterial type, and plant type lysozymes [4-6]. The chicken (cLys) and human (hLys) lysozymes are c-type Lys. The cLys is composed of 129 amino acid residues $(14.3 \mathrm{kDa})$, whereas hLys is composed of 130 amino acid residues $(14.7 \mathrm{kDa})$. There is a $59 \%$ identity between the sequence of human and chicken lysozymes but the antibacterial activity of hLys is three-fold greater than the antibacterial activity of cLys. 
The antibacterial action of lysozyme is particularly efficient against Gram-positive bacteria because of its ability to hydrolyze the $\beta-1,4$-glycosidic bond present in the polysaccharide layer of these bacteria cell walls. The effect against the Gram-negative bacteria is significantly weaker due to the presence of a protective lipopolysaccharides layer on the outer membrane.

Many methods, physical and chemical, have been suggested and successfully developed, and aimed at enhancing the susceptibility of Gram-negative bacteria to lysozyme.

Taking into account the well-known antibacterial, antiviral, antifungal, anti-inflammatory, anticancer, and immunomodulatory activity [7], lysozyme has great potential, mainly in clinical, feed, and food applications, for treating pathogens of a different nature, and numerous examples have been reported in literature.

The continuing increase in bacteria resistance to antibiotics prompts the identification of new molecules or new applications of known compounds, such as the case of lysozyme. The chance of the emergence of resistance to peptidoglycan-degrading enzymes, including lysozyme, are described in an interesting 2020 review [1]. The authors explain that Grampositive bacteria predominantly achieve resistance through peptidoglycan modifications; on the contrary, many Gram-negative bacteria tend to utilize inhibitor proteins that bind the active center of the peptidoglycan-degrading enzymes, blocking their activity. The development of resistance to these enzymes is defined by the authors as a rare event, at least in vitro, emerging not through de novo mutations, but through the horizontal transfer of resistance determinants. The clinical use of peptidoglycan-degrading enzymes is considered as being at less risk of resistance, due to their nature as recombinant proteins.

In the present review, the focus is the more relevant papers and patents published in the last 20 years. The present paper summarizes the main lysozyme source, its application as an alternative antibiotic, its synergism with other compounds, and the physical and chemical modifications aimed to improve its activity.

\section{Sources}

Lysozyme is a ubiquitous enzyme present in all living organisms and viruses with a wide variability in origin, quantity, structural, chemical, and enzymatic properties.

\subsection{Lysozyme in Eggs}

The chicken egg white is the richest source of this enzyme, and it is constituted by about $0.3 \%$ of lysozyme. This enzyme accounts for $3.4-5.8 \%$ of the total egg white proteins [8,9].

The wide availability makes the chicken egg white the main commercial source for this protein. Many efforts are aimed at obtaining lysozyme in a suitably pure form. In 2018, a review was published about the methods of the purification of lysozyme from egg whites [10]. The purification process of ultrafiltration, according to the authors of a 2009 article [11], extends the spectrum of its activity through the formation of lysozyme polymers. Indeed, it is known that the dimerization produces an enzyme that is active against both the Gram-positive and the Gram-negative bacteria (see the physical modifications Section).

Lysozyme was also found in the hen egg shell membrane, and a 2005 study [12] examined the effect of layer breed, bird age, membrane stabilization treatment, and storage time on the enzymatic and biological activity of lysozyme in egg shell membranes. In a later publication [13], it was observed that there was a lower antibacterial activity of purified lysozyme from egg shell membranes than that of purified lysozyme from egg whites.

Lysozyme from the egg white of quail was purified and characterized in 2014 [14], whereas the polymorphism of the egg white lysozyme from Japanese quail was investigated in 2012, and the authors demonstrated that two phenotypes of lysozyme were associated with significant differences in the antibacterial activity of the enzyme [15].

The g-type lysozyme can be isolated from goose egg whites [16]. It has a threedimensional structure like the c-type and T4 phage lysozymes. 


\subsection{Lysozyme in Milk}

Even though the egg white is the richest source of commercial lysozymes, milk from mammals also contains lysozyme molecules endowed with equally interesting properties. Lysozyme is present in mammals' milk, either as a free soluble protein or within leucocytes and lysosomes. The lysozymes from milk belong to the c-type family with a wide variability from one species to another in terms of structure, physicochemical properties, and concentrations. Within the same species, the variation depends on many factors (breed, stage of lactation, parturition nutrition, and season of the year), as reported in a 2008 review [17]. A group of the sampled milks contains high levels of lysozyme (200-1330 mg/L) and another group has levels that are 3000 to 6000 times lower. Human, equine, and canine milks belong to the first group while bovine, ovine, and caprine milks represent the second group. In the same 2008 review [17], a table summarized the concentration of lysozyme in different mammals. According to the authors, the low level of lysozyme in milks of some mammals explains the conflicting literature data about the content, the presence, or the absence of lysozyme in the milk of some species (bovine, camel, and porcine).

Jenny milk is characterized by its high lysozyme content and has been used as an antimicrobial additive in dairy products; it is an alternative to the hen egg white lysozyme which can cause allergic reactions [18].

The buffalo milk lysozyme was purified and characterized in 2002 [19], showing a specific activity that was ten-fold that of the bovine milk lysozyme. The sequence of 23 amino acid residues of the N-terminal end was identified, and it showed a 56.5\% homology with the bovine milk lysozyme and $30.4 \%$ with the equine milk lysozyme.

The N-terminal domain of the human milk lysozyme was treated with pepsin, and the N-terminal helix examined for its antimicrobial activity exhibited a potent bactericidal action to Gram-positive, Gram-negative bacteria, and the fungus Candida albicans, showing a potential use for the treatment of infectious diseases [20].

\subsection{Saliva, Tears, Various Organs, and Tissues of Mammals}

Lysozyme was discovered from a casual observation by A. Fleming [2,21-23] in 1921, when a few drops of his nasal discharge that contaminated an inoculated culture medium blocked the bacterial growth as observed a few days later. The presence of lysozyme in many forms of human secretion (such as saliva and tears) and tissue and organ secretion (such as placenta, sperm, leukocytes, blood) has been well known since then.

Numerous defense proteins are present in saliva and involved in innate and acquired immunity [24]. The same role is carried out by lysozyme in the lacrimal fluid, and its presence in the retinal pigment epithelial cells has been recently demonstrated [25]: the lysozyme expression is modulated, in this case, by pathogenic challenges.

Interestingly, in 2013 [26], authors from Saudi Arabia demonstrated that lysozyme purified from dromedary tears showed significant bactericidal activity against Listeria monocytogenes and Staphylococcus epidermidis, whereas the one purified from human tears was devoid of activity against these two strains.

Research about the c-type lysozyme genes in mice allowed the authors to hypothesize the role in mitochondrial functions of spermatozoon and its contribution to the innate immunity of the male genital tract [27].

Ruminant animals have been considered as lysozyme deficient. The expression of lysozyme in the tears, milk, and blood of cows is low. However, in the stomach, the antibacterial lysozymes were recruited as digestive enzymes useful to exploit plant material as a food resource [28]. In a work published in 2010 [29], the yak stomach lysozyme was compared with the cow stomach lysozyme. The result indicated that the yak stomach lysozyme was more closely related to the cow milk lysozyme than to the cow stomach lysozyme. The authors explained this result by concluding that there is a more recent common ancestor of at least one of the stomach lysozymes with milk lysozyme than with other stomach lysozymes. The interest in ruminant animals is also confirmed in a study [30] of a new c-type lysozyme from Lezhi black goat rumen (147 amino acid residues) sharing 
$70.27 \%$ of its identity with the capra hircus blood lysozyme that, likely, functions in host immunity and digestive systems.

\subsection{Aquatic Organisms}

\subsubsection{Fish}

Lysozyme is present in the mucus, lymphoid tissue, and serum of most fish species but not in cod and wolffish. It has been detected in the oocytes, fertilized eggs, and larval stages of fish species, including coho salmon, sea bass, and tilapia [31].

In aquatic environments, fish are in constant interaction with pathogenic and nonpathogenic microorganisms and, therefore, have developed mechanisms of defense aimed at their survival. The skin layer contains innate and adaptive immune factors that protect against infections. In the skin mucus innate immune factors are higher than in the serum. A study of these factors, comprising of lysozyme, was realized in the skin mucus of five marine teleost fish [32] and three freshwater fish [33], highlighting the variations in the considered fish in order to furnish important information for the aquaculture industry.

Several studies, aimed at identifying amino acid sequences, structure, and antimicrobial activity, focus on the fish lysozyme. The lysozyme from the rock bream (Oplegnathus fasciatus) was characterized in 2011 and classified as a g-type lysozyme [34]. In the same year, the lysozymes from kelp grouper (Epinephelus bruneus) [35] and from turbot (Scophthalmus maximus) [36] were identified and classified as c-type and g-type lysozymes, respectively. Two years later, a c-type lysozyme was isolated and characterized from the leukocytes of a nurse shark [37] and two lysozymes genes, and their recombinant proteins from Asian seabass (Lates calcarifer) were analyzed. In this case, either c-type and a g-type lysozymes were identified. The first was most abundant in the liver and the second was predominantly expressed in the intestine and weakly expressed in the muscle [38]. A g-type lysozyme was identified in 2016 [39] in seahorses (Hippocampus abdominalis), with the highest expression in the kidney and the least expression in the liver.

\subsubsection{Marine Invertebrates}

a. Mollusks

The lysozyme from the viscera of scallops (Patinopecten yessoensis) was purified and characterized in 2008 [40]. With the same aim of identifying new, more active enzymes, the lysozymes of other bivalve mollusks, including Unio pictorum [41] (four-fold more active than the egg lysozyme in the inhibition of E. coli); Asian hard clams (Meretrix meretrix) [42]; freshwater mussels (Cristaria plicata) [43]; and Manila clams (Ruditapes philippinarum) [44], were isolated and identified.

From the mollusk abalone (Haliotis discus hannai Ino), a chicken-type lysozyme was obtained and characterized (147 amino acid residues, 15.64 kDa molecular mass, and pI 4.87). This lysozyme showed bacteriolytic activity against Gram-positive and Gramnegative bacteria [45].

b. Crustaceans

The lysozymes from white shrimp (Panaeus vannamei) [46,47], black shrimp (Panaeus monodon) [48], blue shrimp (Litopenaeus stylirostris) [49], and penaeid shrimp (Marsupenaeus japonicus) [50] were identified, characterized, and their antibacterial properties analyzed. In some cases, the c-type lysozyme was present while in others the i-type was identified.

The characterization of lysozyme from banana prawn (Fenneropenaeus merguiensis) [51] showed a 37-93\% similarity with mouse, human, chicken, and tiger prawn counterparts $(15 \mathrm{kDa})$, and a strong inhibition against shrimp pathogens.

\section{c. Echinodermata}

The lysozyme of sea cucumbers (Stichopus japonicus) was identified in 2009 [52] as an i-type, by cDNA isolation.

d. Anellida

The medicinal leech lives in muddy freshwater pools. In its secretions, from the salivary glands, a multifunctional i-type enzyme, the destabilase-lysozyme, is present. This 
enzyme is endowed with isopeptidase, muramidase, and antibacterial activity. It attracts interest because it also shows thrombolytic activity through the lysis of the bonds $\varepsilon-(\gamma-$ Glu)-Lys present in fibrin. For these reasons, its recombinant isoforms [53] and antifungal activity [54] have been studied.

\subsection{Insects}

The first antibacterial factor purified from insect hemolymph was lysozyme. The insect hemolymph lysozymes have molecular weights and properties similar to those of the hen egg white lysozyme, but a higher enzymatic activity.

Cameraria ohridella is the most dangerous pest to the horse chestnut. In 2005, [55] the lysozyme-type activity of the pupae of this insect was identified against Micrococcus luteus and Bacillus megaterium. Additionally, the lysozyme c-1 of Anopheles gambiae, in the course of its characterization, inhibited the growth of M. luteus but not of E. coli [56]. The possibility of cloning and overexpressing the lysozyme of Spodoptera litura in E. coli offers a method for the production of the biologically active c-type lysozyme as a natural antibiotic $[57,58]$. The same authors applied a similar process to the overexpression of lysozyme from Agrius convolvuli obtaining a peptide active against B. megaterium and $M$. luteus [59].

The larvae of Galleria melonella, the honeycomb moth, parasitize the honeybees, and the economic loss caused by this species prompted numerous studies. The c-type lysozyme of G. melonella is endowed with antifungal activity against Candida albicans, and the mechanism of this action was investigated by a Polish group in 2016 [60].

The awareness of the presence of lysozyme in the hemolymph of honeybees has existed since 1968 [61], and the antimicrobial properties of honey alone [62] or in combination with milk [63] have been reviewed.

A new type of lysozyme from the Chinese oak silk moth (Antheraea pernyi) was investigated and the encouraging results obtained about the strong effectiveness against Gram-negative strains, according to the authors, laid the foundation for future improvement by protein engineering [64].

Moreover, the c-type lysozyme from the Asian corn borer (Ostrinia furnacalis) [65] showed to be active against Gram-positive and Gram-negative bacteria.

Recently, a c-type lysozyme from Coridius chinensis, a medicinal insect resource in China, was identified and analyzed [66].

\subsection{Plants}

A novel plant lysozyme was isolated in 2005 [67] from the mung bean (Phaseolus mungo), with a molecular weight of $14.4 \mathrm{kDa}$, and exhibited antifungal activity toward Fusarium solani, Pythium aphanidermatum, Sclerotium rolfsii, and Botrytis cinerea, and antibacterial action against Staphylococcus aureus. A similar antifungal and antibacterial activity was found in the case of lysozyme isolated from Canadian cranberry beans (Phaseolus vulgaris) [68].

The seed oil from Carthamus tinctorius safflower [69] and the milky juice of papaya fruits [70] are rich sources of proteolytic enzymes, including lysozyme. For this reason, they are applied in the treatment of various skin injuries.

The lysozyme isolated from Momordica charantia L. was found to exhibit antifungal activity toward Mucor racemosus and Rhizoctonia solani, in addition to the antibacterial action against E. coli and S. aureus [71].

\subsection{Microorganisms}

The research of new antibacterial drugs able to overcome the antibiotic-resistant bacteria problem, also focused the attention toward bacteria, bacteriophages, and yeast as sources of new lysozymes.

Recently [72], a Chinese patent reported the identification of a bacteriophage lysozyme and its gene, as well as its use for preventing and treating bacterial infections. 
Pichia pastoris is a methylotrophic yeast which has proven to be an efficient system for the expression of many heterologous proteins. The DNA of an unstable mutant in the hen egg lysozyme was integrated in P. pastoris, and the amount of secreted enzyme was 422 -fold greater than what was observed with Saccharomyces cerevisiae [73]. The same yeast was employed to insert the T4 lysozyme gene, and the obtained protein inhibited the growth of S. aureus and Streptococcus pneumoniae [74]. In another example, P. pastoris was modified with the gene encoding the lysozyme. The produced lysozyme, in the presence of silicic acid, mediated the encapsulation of yeast cells within silica, paving a novel way for the preparation of composites, finalized to biotechnological applications [75].

The lysozyme of Bacillus licheniformis from soil was cloned and expressed in E. coli. The produced lysozyme was resistant to pepsin and trypsin, to some extent at, $40{ }^{\circ} \mathrm{C}$, and efficiently active in the $\mathrm{pH}$ range between 3 and 9 and from $20^{\circ}$ to $60^{\circ} \mathrm{C}$, respectively. The promising properties of this preparation [76] as a food or feed additives was also found for the fungal lysozyme isolated from Trichoderma reesei, showing an antimicrobial activity improved at the acidic $\mathrm{pH}(<6.5)$ [77].

According to the authors [78], another fungal lysozyme, produced by the Chalaropsis species, could be utilized in a variety of settings where bacterial infections proliferate, such as hospital settings (S. aureus) or in veterinary applications (mastitis from S. aureus in cows), and as a means of combating bioterror agents (such as Staphylococcal Enterotoxin B and Clostridium botulinum).

Chitinases are the enzymes which hydrolyze chitin, the $\beta$-1,4-linear polymer of $\mathrm{N}$ acetylglucosamine, one of the most abundant natural polysaccharides. A bifunctional chitinase/lysozyme from Bacillus pumilus, capable of degrading the chitin component of fungal cell walls and the peptidoglycan component of cell walls of many kinds of bacteria (Xanthomonas translucens, Xanthomonas axonopodis, Bacillus licheniformis, E. coli C600, E. coli TOP10, Pseudomonas aeruginosa, and Pseudomonas putida), was cloned and expressed in the E. coli strain M15 [79]. The chitinases from plants and animals are frequently endowed with lysozyme activity, whereas the bifunctionality of microbial chitinases is rare.

\subsection{Recombinant Human Lysozyme (rhLys)}

The great antimicrobial activity of lysozyme makes it interesting in medicine, cosmetics, and the food industry. The chicken egg white lysozyme is commonly used for these purposes but individuals sensitive to chicken eggs have also demonstrated an allergic reaction to the lysozyme isolated from egg whites. Many investigations have been carried out to produce the human lysozyme, considering its limited source, in bacteria, yeast, plants, and other organisms. In a 2006 patent [80], the preparation and the purification of rhLys with a transgenic organism, E. coli, was described. The obtained protein exhibited enzymatically active bacteriolytic properties, showing that $E$. coli can produce a functionally active human lysozyme. A bioreactor, with plastic composite support, was used to optimize the growth parameters of Kluyveromyces lactis K7, a genetically modified organism that expresses the human lysozyme [81].

A novel human c-type lysozyme was produced in recombinant Pichia pastoris using a fed-batch strategy; the obtained lysozyme showed a specific activity toward Micrococcus lysodeikticus of $7069 \mathrm{U} / \mathrm{mg}$ (Micrococcus lysodeikticus is a Gram-positive organism, isolated by A. Fleming when he discovered lysozyme. It is the standard microorganism utilized for the evaluation of muramidase activity. The current name for M. lysodeikticus is M. luteus [82]; in this review, we have used the former name or the new one, depending on the choice by the authors of the cited articles), suggesting a possible industrial application [83]. The expression of rhLys in Pichia pastoris, fused with the peptide tachyplesin I, was reviewed in 2013 [84].

Lysozyme is highly expressed in human milk but is found only in trace amounts in cow's milk. In a work conducted in 2011, 17 healthy cloned cattle expressing the recombinant human lysozyme were produced. The transgenic cattle milk offered similar nutritional benefits as human milk, and the described techniques are appliable for the 
production of the active human lysozyme on a large scale [85]. More recently, recombinant human lactoferrin and lysozyme were produced and characterized in a bi-transgenic cow. The enzymatic activity of the lysozyme in the transgenic milk was comparable to that of human milk, which is 6 and 10 times higher than that of the bovine lysozyme present in milk [86].

A bovine mammary gland expression vector, expressing the human lysozyme gene, was constructed and tested on lactation rabbits [87] and in mouse mammary epithelial cells [88]. Transgenic mice were also developed for the expression of large amounts (18.5-35 g/L) of rhLys in milk [89], representing a model system for the cost-effective production of hLys. I previous studies, significantly lower amounts of lysozyme (1.20-1.76 g/L) were obtained using similar approaches [90-92].

Transgenic swine expressing rhLys were generated by a somatic cell transfer, with the aim to feed piglets with the human lysozyme to avoid pathogenic infections and, hence, a negative impact on neonatal survival. One of the 3 cloned female pigs expressed rhLys at $0.32 \mu \mathrm{g} / \mathrm{mL}$ in milk, 50-fold higher than the native pig lysozyme [93].

Transgenic dairy goats that expressed the human lysozyme in their milk, at $68 \%$ of the level normally found in human milk, were developed, in order to extend the beneficial protective properties of human milk into livestock milk and make it readily available for people of all ages $[94,95]$.

Both the chicken egg lysozyme and human lysozyme belong to the c-type. Although the chicken egg lysozyme is easily obtained from egg whites, hLys displays a 3-fold higher antibacterial activity and is more thermal stable. For these reasons, transgenic chickens suitable for the production of active rhLys, were generated and the analysis of the obtained rhLys showed physicochemical and biological properties similar to commercial hLys. Moreover, the transgene of rhLys was genetically stable across the different generations [96].

Th breast feeding of fresh human milk has traditionally been considered the best means for providing nutrition to infants; indeed, it has been demonstrated that lysozyme and other milk proteins are immune factors that compensate for the undeveloped defense mechanism of the gut of infants [97]. For the situations in which the mother's milk is not available, synthetic infant milk formulas are used in the place of breast feeding. In this context, the expression of human milk proteins (including lysozyme) in transgenic plants was developed.

A synthetic gene of hLys was introduced into the calli of rice [98]. The obtained rhLys was purified and the amino acid sequence verified, showing the promising potential for using a rice-derived lysozyme as a food supplement for infant formula and baby foods. The transgenic rice expressing lactoferrin and lysozyme was fed to chicks, showing antibioticlike properties similar to subtherapeutic doses of baritrocin + roxarsone in the protection of the intestinal tract [99].

\section{Applications of Lysozyme}

The large number of investigated sources of different types of lysozymes can be explained by the many applications in medicine, cosmetics, the food industry, and agriculture. The wide spectrum of applications depends not only on its antibacterial activity, but also on the inactivation of certain viruses and fungi.

The antibacterial activity against Gram-positive bacteria has been explained by the lysozyme enzymatic action on the peptidoglycans present in the cell wall. The peptidoglycans present in the inner membrane of Gram-negative bacteria are shielded by a lipidic outer membrane, but the lysozyme shows, even if weakly, to be active. Some authors explained this activity, proposing that the antibacterial mechanism of action is independent of its enzymatic activity, also in the case of Gram-positive bacteria. The role of the lysozyme, according to this hypothesis, is the removal of the cell wall of the bacteria previously killed by antimicrobial polypeptides. Ibrahim et al., in 2001 [100], showed that the catalytically inactive mutant of the hen egg white lysozyme was as bactericidal as the wild -type lysozyme against $S$. aureus and B. subtilis. An opposite opinion was suggested in the same year by 
Masschlck et al. [101], who observed that a high pressure treatment, in the presence of lysozyme, sensitized a series of Gram-negative bacteria; the denaturation of lysozyme, by heat treatment, fully eliminated the bactericidal effect observed under high pressure conditions, while a partially denatured lysozyme maintained its activity. The bactericidal effect, due to the high-pressure treatment, was observed also in the case of two peptides, devoid of enzymatic activity, obtained from lysozyme: the authors ascribed these results to the cationic nature and the increased hydrophobicity of the chains.

The role of cationic peptide chains (the depolarization and permeabilization of membranes) was discussed in an article published in 2004 [102], together with the hypothesis of the indirect bactericidal action of lysozyme: the cationic peptide can behave as antibacterial by activating an autolytic wall muramidase of bacteria (a phenomenon defined as "Trojan horse"), resulting in bacteriolysis.

The action mechanism of lysozyme was studied also in vivo to verify if its activity depends or not on the muramidase action. From the observed results in transgenic mice deficient in lysozyme or expressing a muramidase-deficient lysozyme transgene, the authors concluded that lysozyme kills bacteria independently of its muramidase activity [103].

The cationic nature of the lysozyme chain was hypothesized to be the cause of its fungicidal activity. The ionic interactions between the cationic peptide and the anionic structures in the microbial cell wall can result in the damage to the cell wall, which is disrupted by a subsequent event, such as the exposure to salt and detergent by the effect of osmotic pressure. [104].

In an article published in 1999, the presence of a protein with the N-terminal 15 amino acids sequence identical to the human urinary lysozyme $C$ in preparations of the $\beta$-subunit of human chorionic gonadotropin, was reported. The antiviral activity of this protein and of the lysozymes from chicken egg whites, from human milk, and from human neutrophils against HIV-1, was explained by the authors as being due to the degradation of viral polysaccharides [105].

The number of suggested potential mechanisms of action is as wide as the field of lysozyme applications against microorganisms, which differ greatly from one another.

\subsection{Medical Applications}

\subsubsection{Skin Diseases}

The milky juice of papaya fruits is a source of proteolytic enzymes, including lysozyme, and it is applied in surgery for the treatment of fistulas, cleaning wounds from necrotized tissues, and for skin grafting [70].

High antibacterial effects produced by both bacteriostatic and bactericidal pathways, including lysozyme activity, was demonstrated for the seed oil from Carthamus tinctorius (safflower) [69], in the management of skin injuries.

Staphylococcus aureus is the most common cause of primary and post-operative skin infections, and it has become increasingly resistant to antibiotics, such as methicillin and vancomycin. The use of lysozyme from egg whites and its dextran conjugate was investigated as an alternative topical ointment for the treatment of the infected skin of mice [106]. The two preparations were tested in vitro against S. aureus and E. coli. The results showed that both the lysozyme and lysozyme conjugate exhibited antibacterial activity against $S$. aureus, but only the lysozyme conjugate was active against $E$. coli. The activity of the conjugated lysozyme was explained by the authors by the strong surface activity which can enhance the lytic action of the enzyme toward the peptidoglycan layer in the inner membrane. The studies on mice also confirmed the improvement of the antibacterial activity of the lysozyme in wound healing, due to the conjugation with dextran. The activity of the dextran conjugated lysozyme was comparable with tetracycline, suggesting that lysozyme is a natural antimicrobial agent and a suitable replacement for synthetic antibiotic.

In a 2017 publication [107], a smart antimicrobial system, activated in the case of infection, based on elevated lysozyme activity, was presented. A synthesized N-acetyl 
chitosan was subjected to the lysozyme hydrolysis in artificial wound fluid, presenting $\mathrm{N}$-acetylated chitooligosaccharides (COS). COS, by action of cellobiose dehydrogenase, afforded antimicrobial hydrogen peroxide $(1 \mathrm{mM})$, which is able to inhibit the growth of $E$. coli and S. aureus (Figure 3).

\section{cellobiose $\mathrm{N}$-acetyl chitosan $\stackrel{\text { lysozyme }}{\longrightarrow} \mathrm{COS} \stackrel{\text { dehydrogenase }}{\longrightarrow} \mathrm{H}_{2} \mathrm{O}_{2}$}

Figure 3. Antimicrobial system involving lysozyme.

A T4 lysozyme fused with a cellulose binding module was prepared and immobilized to a wound dressing gauze. The immobilized protein retained the bacterial activity against Gram-positive and Gram-negative bacteria. The unmodified T4 lysozyme could not bind to the gauze. The immobilized lysozyme can constitute an innovative strategy for producing antimicrobial wound dressing materials [108].

Acticoat, an antibacterial silver nanoparticle-loaded dressing, is a commonplace for the prevention of infection in burns and with open wound patients. The efficacy of this dressing against methicillin-resistant $S$. aureus (MRSA) was evaluated, investigating additives that can improve its activity [109]. The greatest reduction in bacterial survival was observed when Acticoat was soaked with a combination of $10 \%$ glycerol, lysozyme $(1 \mathrm{mg} / \mathrm{mL})$, and an antimicrobial peptide (bac $8 \mathrm{c}$, a truncated and modified bovine neutrophile peptide).

A promising preparation for the development of antibacterial wound dressing was obtained in 2018 [110], starting from hairy steric stabilized nanocrystalline cellulose (SNCC) functionalized with aldehyde groups; by the reaction of these groups, lysozyme or nisin was immobilized on cellulose. Lysozyme and nisin in free and immobilized forms were tested against $B$. subtilis and S. aureus. S. aureus is the bacterial species more commonly detected in infected wounds and $B$. subtilis is closely related to several animal pathogens, including $B$. cereus, which is associated with wound infections. Immobilized nisin showed to be active against $S$. aureus, whereas free nisin became ineffective against the growth of $S$. aureus after $24 \mathrm{~h}$. Lysozyme was not effective against $S$. aureus, but the immobilized lysozyme was active against $B$. subtilis. The authors of the study suggest that the combination of antimicrobial agents immobilized onto SNCC can offer an effective broad spectrum antibacterial wound dressing.

Recently [111], the effect of wound moisture on wound healing was studied considering the moisture balance of a polyurethane foam dressing. A moisture balanced antibacterial dressing was constructed by loading lysozyme onto a polyurethane foam dressing, by means of dopamine adsorption. The prepared dressing experiment in wound healing in infected mice provided the appropriate wound moisture and at the same time prevented bacterial infections.

The most common skin disorder is the acne vulgaris caused by Propionobacterium acnes. The use of lysozyme-shelled microbubbles (MBs) and ultrasound-mediated LysMBs cavitation against $P$. acnes, in vitro and in vivo, aimed to reduce the dose and the duration of antibiotic therapy, was investigated [112]. The results of the study showed that the combined Lys-MBs and ultrasound significantly reduced the treatment duration and inhibited P. acnes-induced skin diseases.

A different approach to the control of P. acnes by lysozyme was proposed in 2018. Bacteriocin AS-48 is a 70-amino acid residue circular peptide produced by different Enterococcus species, endowed with bactericidal activity on many Gram-positive and Gram-negative bacteria. The effectiveness against $P$. acnes by AS- 48 alone, and in combination with lysozyme, was examined using a range of microscopy and bioassay techniques. The improvements of the action of AS-48 through the combination with lysozyme showed that these two natural compounds are promising candidates against dermatological diseases, such as acne vulgaris [113].

The use of a lysozyme gel formulation in the disinfection of the skin, during pre- and post-surgery, for facial care and the care of hands, feet, and nails, was reported in a 2013 U.S. 
Patent [114]. The gelled lysozyme was prepared by the addition of water to a suspension of lysozyme in alcohol, without the addition of other gelling substances. The formulation, retaining the enzymatic activity, was successfully used for local applications in the preand post-operative therapy of phlebopathic patients.

A polyethylene-based material loaded with an antibiotic is often used as a surgical sealant, but the developed drug resistance prompted the development of a variety of bioactive molecules modified by a PEG-based hydrogel. The antibacterial activity of lysozyme prompted the development of a PEG-lysozyme injectable sealant. A four-arm PEG suitably functionalized at each terminal arm was linked to lysozyme through its amine groups. It was observed that the hydrogel sealed gas or blood leakage in a rabbit trachea, and it could close the transmural left ventricular wall defect. The bacteriostatic activity was demonstrated against $S$. aureus and E. coli [115].

\subsubsection{Medical Devices}

Bone tissue engineering plays a crucial role in regenerating defective or lost tissue. The selection of material is important since it is necessary to consider the biological properties of living cells and the physicochemical properties of the materials. A silica precursor was blended with a $\mathrm{SiO}_{2}-\mathrm{CaO}-\mathrm{P}_{2} \mathrm{O}_{5}$ mesoporous bioactive glass solution. Lysozyme was encapsulated into the scaffold, which exhibited an ability to delay the $\mathrm{pH}$-triggered lysozyme release endowed with antibiotic activity [116].

A silicon rubber film modified with $\mathrm{N}$-vinyl caprolactam was prepared with the aim to reversibly load and release lysozyme for medical devices. The enzymatic activity was assessed against Micrococcus lysodeikticus [117].

Pelvic organ prolapse is a benign post-partum gynecological disease which seriously affects the quality of life of middle-aged and elderly women. Mesh, mainly polypropylene, is a material used for pelvic floor reconstruction. The postoperative complications prompt to find alternative materials. In a recent article [118], lysozyme and collagen were alternatively deposited on silk fibroin and nylon 6 composite nanofibrous mats through a layer-by-layer self-assembly method. Silk fibroin was chosen for its biological compatibility, biodegradability, and low immunogenicity. The poor mechanical properties of silk fibroin nanofibers were overcome by blending silk fibroin with nylon 6 , a synthetic polymer with excellent mechanical strength. These mats showed an over $98 \%$ reduction in the viable count of $S$. aureus. The less encouraging results against $E$. coli can be explained because lysozyme is less sensitive to Gram-negative bacteria.

The immobilization of lysozyme onto woven or knitted PET [119], decreased the adhesion of vein catheter-isolated Staphylococcus epidermis by 6- to 8-fold and of S. aureus by 11- to 12-fold, while the Gram-negative E. coli showed a decrease of 3- to 4-folds. Immobilized lysozyme on PET can inhibit the graft-associated infection.

The oral healthcare of aged people is an issue of great interest and importance due to ageing societies. The development of self-cleaning materials is closely related to the adsorption phenomena on both dental material and teeth of antibacterial agents. These agents can be synthetic compounds or naturally secreted substances, such as lysozyme. The quartz crystal microbalance method associated with dissipation monitoring is a technique suitable for sensing the "softness", or viscoelastic properties, of the adsorbed layer. Through this method, the adsorption of lysozyme on the Au sensor, $\mathrm{SiO}_{2}$ sensor, or $\mathrm{TiO}_{2}$ sensor, were studied at different $\mathrm{pH}$ conditions and salt concentrations [120]. The affinity of lysozyme was in the order of $\mathrm{Au}>\mathrm{SiO}_{2}>\mathrm{TiO}_{2}$ sensors. The $\mathrm{pH}$-dependent charge of oxide surfaces showed to influence the lysozyme adsorption, suggesting that the nature of the adsorption on the oxide surface was electrostatic.

The osteointegration of dental implants with surrounding tissue and the presence of infection at the implant site are critical factors in the success of dental implants.

Graphene oxide, a nanosheet with a thickness of several atoms, has a large surface area and it is rich in functional groups. It possesses an appreciable ability to kill Gram-positive and Gram-negative bacteria, due to its behavior that resembles a nano knife being able to penetrate 
and cut the cell membrane. However, this nonspecific mechanism also affects other cells, leading to a biotoxicity strictly related to the concentration. In 2020 [121], graphene oxide was integrated with lysozyme and tannic acid into a thin coating using a layer-by-layer method. The tannic acid extracted from plants has antibacterial properties and strong osteogenesis, due to its binding to calcium ions. Subsequently, the new coating was characterized by the beneficial effects of the integrated components. The layer-by-layer method allowed us to overcome the concentration-dependent graphene oxide toxicity because a very low amount was required to cover the entire substrate. The efficacy of this coating was demonstrated against the Gram-positive S. aureus and the Gram-negative E. coli.

A lysozyme coating was proposed again in 2020 [122], with the aim to improve the corrosion resistance of new orthodontic composite arch wires (CAWs). The CAWs are made of a nickel and titanium alloy and stainless steel produced by laser welding, with copper serving as the interlayer. The copper interlayer can be damaged in the corrosive oral environment. The lysozyme coated arch wires were prepared using a liquid phase deposition with different concentrations of the enzyme. The corrosion behaviors of the CAWs and their antibacterial performance were examined: the composite arch wires coated with $20 \mathrm{~g} / \mathrm{L}$ of lysozyme showed fewer corrosion pit and less corrosion depth relative to the uncoated CAWs. The concentration of $40 \mathrm{~g} / \mathrm{L}$ of lysozyme was identified as the ideal future clinical application by the results observed against $S$. aureus.

\subsubsection{Biofilms}

Biofilms are matrix-enclosed accumulations of microorganisms, such as bacteria, fungi, protozoa, and viruses. They are rarely composed of a single type of cells. The non-cellular components can be carbohydrates, proteins, lipids, lipoproteins, and lipopolysaccharides. The adhesion of microorganisms can be encountered in the food environment (food processing and packaging). Some of the nosocomial infections are caused by the use of biomedical devices on which the biofilm of Staphylococci bacteria grow. Frequently, the common surface cleaning procedures are not sufficient against mature biofilms. Biofilm structures cause the reduced response of bacteria to antibiotics and weakens the bactericidal actions of antimicrobial and sanitizing agents. Many efforts are focused on the identification of surfaces able to prevent the adhesion of microorganisms and, at the same time, exhibiting biocide properties.

In a 2004 U.S. Patent [123], the preparation method of a two-component composition of two anchor enzyme complexes was described. The first complex degrades the biofilm structures. For example, it contains alginate lyase to degrade the polysaccharide matrix in which Pseudomonas aeruginosa can grow and proliferate. The second anchor-enzyme complex contains the lysozyme necessary to lyse the bacteria within the biofilm. This composition can be utilized on implanted medical devices (catheters and cannulae) to control a variety of infections.

Enterococcus faecalis is a Gram-positive gastrointestinal commensal and a leading cause of nosocomial infections. E. faecalis infections are difficult to treat because it forms biofilms and is resistant to many antimicrobial agents. The effect of lysozyme (from chicken egg white and rhLys) on E. faecalis biofilm was studied in a 2019 patent and a kit with lysozyme was developed for treating such a bacterial infection [124].

In another case [125], with the aim to protect stainless steel surfaces, the lysozyme from a hen egg white and PEG were coated onto the surfaces. The surfaces coated with the enzyme displayed high antiadhesion activity toward Listeria ivanovii and a marked local biocide activity on Micrococcus luteus.

In another biofilm study, stainless steel surfaces were chosen as the starting material in order to obtain a material with a bactericidal function [126]. The surface was first activated by a biomimetic catechol (dopamine) anchor; the amino group of dopamine was treated with glutaraldehyde, a bifunctional linker. Chitosan was covalently immobilized by the reaction with glutaraldehyde. Finally, lysozyme (from the hen egg white) was conjugated to the chitosan (Figure 4). Chitosan is a well-known biopolymer endowed 
with antibacterial activities against bacteria, fungi, and algae [127]. The modified surface showed that the properties of both chitosan and lysozyme were preserved, and a substantial enhancement of the activity against bacterial adhesion and bactericidal efficiency against S. aureus were observed on the lysozyme-immobilized substrates relative to the chitosangrafted substrates.

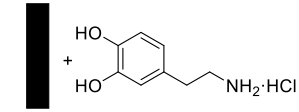

Ss-OH

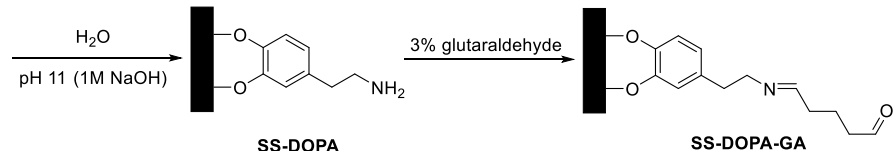

SS-DOPA

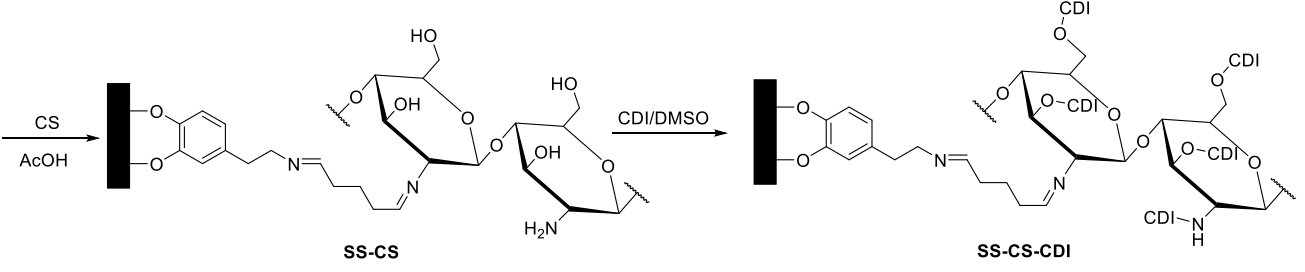

Lysozyme

Lysozym

Lysozyn

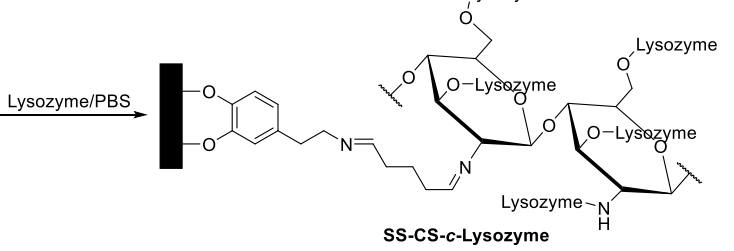

$\mathrm{CS}=$ chitosan

$\mathrm{CDI}=$ carbonyldiimidazole

Figure 4. A schematic diagram illustrating the process of coupling dopamine, bifunctional crosslinker glutaraldehyde, chitosan, and lysozyme.

The immobilization of lysozyme on chitosan would offer a method for combating the biofilm-related contamination of stainless-steel implants and devices.

Streptococcus pneumoniae is a Gram-positive bacterium which causes many infections, ranging from the common and usually mild otitis and rhinosinusitis to invasive diseases, such as sepsis, pneumonia, and meningitis. Since it has become increasingly resistant to antibiotics, new antimicrobials have been developed, including the use of bacteriophages and some of their products. Two pneumococcal phage lysozymes (Cpl-1 and Cpl-7) were chosen with the aim to construct four dimeric proteins by shuffling their two functional domains and the linkers. The ability of these new enzymes to reduce pneumococcal biofilm formation and the killing activity against pneumococcal bacteria were studied in mice. One of them showed a greater bactericidal capacity than the natural Cpl-1, confirming the power of this new chimeric enzyme [128].

Another Streptococcus, S. mutans, causes the formation of a biofilm in the human oral cavity and tooth decay. A study was carried out to improve the activity of marine Arthobacter oxydans KQ11 dextranase mouthwash by the best combination of $\mathrm{ZnSO}_{4}$, lysozyme, citric acid, and chitosan. The optimized formula tested in marine dextranase mouthwash enhanced the inhibition of S. mutans [129].

Antibacterial photodynamic therapy is used for caries, endodontic disease, periodontitis, and peri-implantitis. This technique utilizes reactive oxygen species, such as singlet oxygen and free radicals via photosensitizers, to reduce bacterial infections. In order to overcome the narrow spectrum of excitation wavelengths to generate $\mathrm{O}_{2}$ of the commonly chosen photosensitizers, a novel Au nanocluster photosensitizer was proposed [130]. This novel photosensitizer is a lysozyme-gold nanocluster (AuNCs)-rose Bengal (RB) conjugate. This conjugate showed to effectively inhibit the growth of oral Gram-negative and Grampositive bacteria when exposed to white light-emitting diode irradiation. The photoexcited Lys-AuNCs-RB successfully decreased the formation of S. mutans biofilm.

The formation of biofilm around implants is the primary cause of infections in the mucosa and bone adjacent to the implant. The incorporation of antibacterial compounds 
into the coating of dental implants is an effective strategy to prevent biofilm formation. Lysozyme was immobilized on titanium surfaces forming an initial functional layer. This base was subsequently coated with silver nanoparticles, chitosan, and hyaluronic acid via a layer-by-layer, self-assembly technique. The obtained surface was examined by SEM and X-ray photoelectron spectroscopy. The inhibition of the biofilm formation and the antibacterial activity were evaluated against $S$. aureus. The results showed that the modified Ti surfaces were effective in preventing bacteria colonization for 14 days, until mucosa healing [131].

The same techniques were followed, starting from a metal laser sintered Ti implant primed with phase-transited lysozyme, loading minocycline into polyelectrolyte multilayers, obtained, in turn, by the self-assembly of negative charged hyaluronic acid and positively charged chitosan, natural polysaccharides, non-toxic, and biodegradable [132]. The obtained modified titanium exhibited a strong antibacterial effect against the oral bacteria Streptococcus sanguis and Streptococcus gorgonii, two pathogenic species in the biofilm formation process.

Candida albicans is a yeast present in the oral cavity that can incorporate that form into biofilms on denture surfaces, leading to, in some cases, denture stomatitis. Lysozyme present in saliva (1-57 $\mu \mathrm{g} / \mathrm{mL}$ ) contributes to the control of oral microflora. In 2017, an in vitro study [133] investigated the effects of lysozyme on C. albicans biofilm formation. The results showed that at a low concentration $(<30 \mu \mathrm{g} / \mathrm{mL})$, lysozyme reduced the attached biomass, whereas with concentrations of $>300 \mu \mathrm{g} / \mathrm{mL}$, a pro-biofilm effect was observed.

Among the substances suitable for use as a raw material, for the preparation of surfaces effective for inhibiting biofilm formation, polyhydroxyalkanoate [134] was chosen to form sheets, onto which lysozyme was loaded. The maximum loading was $16.1 \mu \mathrm{g}$ enzyme per $9.5 \mathrm{~mm}^{3}$ disks. These sheets, endowed with an effective inhibition for biofilm formation, can find an application for the fabrication of wound dressing in anti-biofilm treatments.

To remove bacteria biofilm, new ways to deliver antimicrobial agents in a sufficiently high concentration are required. Liposomes are considered as an attractive carrier for drug delivery for their potential to fuse with phospholipid membranes. The spontaneous fusion, resulting in payload loss, can cause a problem. In 2017 [135], a Chinese team proposed a novel lysozyme preparation as a gentamicin carrier. The antibiofilm activity of lysozyme, associated liposomal gentamicin, was tested against Pseudomonas aeruginosa, a Gram-negative human pathogen. This microorganism causes chronic pulmonary infections and is generally employed as a model organism for the investigation of biofilm. The study demonstrated that the positively charged lysozyme stabilized the negative-charged liposomes, and the lysozyme-associated liposomal gentamycin was more effective against the biofilms built by Gram-positive (S. aureus) and Gram-negative bacteria than lysozyme or gentamycin alone.

The lysozyme activity, in combination with cefepime or ceftazidime against the Pseudomonas aeruginosa biofilm, was recently studied [136]. The results showed that 50 times of the minimum inhibition concentrations (MICs) of 2 cephalosporins, in presence of lysozyme ( $30 \mu \mathrm{g} / \mathrm{mL})$, significantly inhibited the $24 \mathrm{~h}$-old biofilm that was formed, when compared with individual antibiotic treatment. The highest inhibitory effect (a $49.3 \%$ reduction) was observed with the combination of cefepime and lysozyme. This method can be applied to the eradication of $P$. aeruginosa biofilms from catheters, ocular lenses, intravascular devices, and ventilator tubes.

This synergistic effect against $P$. aeruginosa was also observed when a combination of ciprofloxacin (at sub MIC of $1.56 \mu \mathrm{g} / \mathrm{mL}$ ) with lysozyme was applied. Indeed, in the case of the combination, a $56 \pm 0.6 \%$ biofilm eradication was obtained, whereas a $40 \pm 0.5 \%$ eradication was observed with ciprofloxacin, alone [137].

The co-administration of an antibiotic, clindamycin, or metronidazole, and rhLys, improved both the efficiency of the antibiotics and the lysozyme-driven biofilm degradation. This cotreatment was applied in an in vitro study on the biofilm of Gardnerella vaginalis, the bacterium involved in vaginal infections. Often, the antibiotic treatments are not 
resolutive and the patients suffer from recurrent infections, probably due to the inability of the antibiotics to reach the bacteria embedded inside the biofilm. The bactericidal and biofilm degradation effects, tested in this in vitro study, were greater than when lysozyme or antibiotics was tested alone [138].

The application of nanotechnology can overcome the difficulty exhibited by most antibiotics to cross the barriers of biofilm. In this context, C-dots, a new class of carbon nanomaterials, were synthesized from papaya leaf extracts and encapsulated with lysozyme into chitosan nanocarrier forming C-dots carriers (CDCs) [139]. The antibacterial activity of CDC was tested on B. subtilis (Gram-positive) and ampicillin-resistant E. coli (Gramnegative). The biofilm inhibition was studied on pellicle of B. subtilis. The combination of C-dots and lysozyme delivered by chitosan nanocarriers, inhibited the growth of both Gram-positive and Gram-negative bacteria, but more efficiently against Gram-positive bacteria. In addition, CDCs showed the capability not only to inhibit the biofilm formation, but also to eradicate the established biofilm. The authors are investigating the antibiofilm activity of CDCs on the surface of medical implants.

\subsubsection{Oral Care}

The antibacterial properties of lysozyme recently found applications also in the preparation of oral care solutions [140], stain-removing and whitening toothpaste [141], oral sprays [142], antibiomembrane remineralization material for root canal irrigation, and blocking treatment of dentin caries [143].

Recently, an oral cavity care spray containing lysozyme was proposed for dogs and cats [144].

A reduction of gingival inflammation was observed by the treatment of chronic periodontitis with a combination of vitamin C, vitamin E, lysozyme, and carbazochrome [145].

The antimicrobial activity of lysozyme against cariogenic microorganisms was evaluated in vitro. The bactericidal and bacteriostatic effects against Streptococcus mutans $(68.5 \mathrm{mg} / \mathrm{mL}$ and $58.7 \mathrm{mg} / \mathrm{mL}$, respectively) and Lactobacillus casei $(50.3 \mathrm{mg} / \mathrm{mL}$ and $43.1 \mathrm{mg} / \mathrm{mL}$, respectively) were quantified. The two microorganisms were not affected by lactoferrin, another saliva protein, or by the synergic use of lysozyme and lactoferrin [146].

The growth inhibition of Streptococcus mutans, by a mixture of casein phosphoprotein/amorphous calcium phosphate, lysozyme, lactoferrin, and lactoperoxidase, was evaluated in a caries model. The results showed that the progression of carious lesions was prevented [147].

The role of salivary proteins, including lysozyme, in cariology, was reviewed in 2004 by a Dutch team [148].

\subsubsection{Respiratory Disorders}

The administration of lysozyme by aerosol for the treatment of respiratory disorders, was suggested in a 2001 U.S. Patent [149]. Moreover, according to the same authors, it can be used as vehicle for the intratracheal administration of drugs to the lungs [150].

Aerosolized rhLys was used as an alternative to conventional antibiotics, to treat induced pneumonia in hamsters. The animals were inoculated with P. aeruginosa, then treated with a $1 \%$ solution of rhLys in water $(2 \mathrm{~h} \times 3$ days). The treatment significantly reduced the parameters related to pneumonia, such as the bacterial colony-forming in the whole lung and bronchoalveolar lavage fluid (BALF), and the total BALF leukocytes. [151].

$P$. aeruginosa is the major airway pathogen in patients with cystic fibrosis. A fusion protein, composed of lysozyme and surfactant protein $B$, was proposed for the prophylaxis or the therapeutic strategy for suppressing the bacterial colonization of the airways in cystic fibrosis patients. The efficacy of the fusion protein was studied in transgenic mice, expressed with this combination of lysozyme and surfactant protein $B$, after intra-tracheal injections with $P$. aeruginosa. The bacterial clearance was enhanced from six- to thirty-fold in mice from different transgenic lines, compared to the values observed in wild-type controls [152]. 
The occurrence of long-term infections in cystic fibrosis is also due to the inactivation of native airway defense. The inflammatory response to the infections causes the formation of high concentrations of negatively charged polymers, which bind and sequester natural positively charged antimicrobial and antibacterial proteins. The reduction of this sequestration by means of the oppositely charged polymers in the airways was the object of a 2007 patent. A human lysozyme was charge-modified by reducing the net charge to a less positive charge level. The charge-modified lysozyme was composed by a first segment having the amino acid sequence of a natural lysozyme and a second segment having from two to ten negatively charged amino acids. A composition of the charge-modified lysozyme and a cationic lipid decreased the antimicrobial sequestration, which reduced the lysozyme binding to actin or DNA, two polyelectrolytes naturally produced from the inflammatory response [153].

The actin-lysozyme complexes formed in cystic fibrosis disease were studied in 2006 [154] and, more recently, in 2016 [155], by synchrotron small-angle X-ray scattering and molecular dynamic simulations, in order to establish their structure, stability and behavior in the presence of the physiological salt concentration of airways.

\subsubsection{Gastrointestinal Tract Diseases}

Patients who take drugs, such as proton pump inhibitors to reduce or treat gastric hyperacidity, have a stomach $\mathrm{pH}$ value of around 5. This value allows Enterobacteriaceae, for example, certain strains of $E$. coli, to pass through the degraded gastric barrier.

Compositions of $\mathrm{N}$-acetylcysteine and microencapsulated gastro-protected lysozymes with probiotic bacteria were proposed in a 2014 patent, to restore the stomach's barrier effect, avoiding the suspension of the pharmacological treatment that would expose gastric and esophageal mucosa to the damage caused by gastric juices and the risks of infections. In the patent, the quantity of $\mathrm{N}$-acetylcysteine, lysozyme, and the list of possible probiotic bacteria were reported. The proposed composition comprised of strains capable of producing bacteriocins, and it is a useful adjuvant in the treatment of Helicobacter pylori [156].

The lysozyme of the microbial source was also proposed for suppressing the growth and/or intestinal colonization of bacterial pathogens in the gastrointestinal tract, and in the treatment of irritable bowel syndrome or inflammatory bowel disease (Crohn's disease and ulcerative colitis). The composition can be administered in the form of foods or dietary supplements [157].

A new lysozyme composition containing natural biological correctors to prevent iron deficiency, calcium deficiency, and gastric disorders was developed in Kazakhstan. In addition to lysozyme, this food supplement contains herbal substances, briar pectin, and dry whey, a calcium-containing product [158].

The genus Salmonella is known as an agent that causes diarrheal disease in humans. Salmonella $\mathrm{O} 48$ strains cause enteritis in humans, especially children, and in animals. They are sensitive to the bactericidal action of normal bovine serum and normal human serum. The serum complement system consists of at least 35 proteins and it is a part of the adaptive and innate immune system. The activation of complement is achieved through three different pathways. In order to establish the role of lysozyme in the mechanism of the activation of bovine and human complement, a study was carried out in 2009 [159]. Lysozyme was removed from serum by adsorption on montmorillonite. The results showed that the most efficient killing of Salmonella $\mathrm{O} 48$ was obtained when all the components of bovine or human serum cooperated, and that the lysozyme was an obligatory factor in the bactericidal action of the components of normal bovine serum and human serum, taking place on the activation mechanism.

\subsubsection{Ophthalmic Applications}

Lysozyme is one of the major components in human tears, where it plays the role of natural defense against ocular infections. 
In the situations of dry eye or inflammation (for example ulcerative herpetic keratitis), tears are not being produced in the normal quantity or quality, or are not produced at all. For this reason, many ophthalmic solutions contain the hen egg white lysozyme. However, its use may cause allergic reactions. In a 2008 U.S. Patent [160], rhLys, instead of the hen egg white lysozyme, was used as the agent that afforded protection from microorganisms, not only for the ophthalmic solutions themselves but also of the eyes to which they were applied. The hLys containing solutions can also be used to condition and clean contact lenses.

The posterior capsule opacification (secondary cataract) is a complication that occurs from having cataract surgery, due to the immune response or the adhesion and reproduction of residual human lens epithelial cells (HLECs) on the posterior capsule. Infectious endophthalmitis is another complication, due to bacterial colonization (coagulase-negative Staphylococci and S. aureus) and biofilm formation. Hyaluronic acid-lysozyme composite coating was covalently grafted onto the surface of intraocular lenses (poly-methylmethacrylate). The presence of hyaluronic acid, due to its hydrophilic properties, reduced the adherence of $S$. aureus and HLECs on the poly-methylmethacrylate, whereas lysozyme (from hen eggs white) exerted its own bactericidal activity against $S$. aureus, as shown in the in vitro test. The immobilized lysozyme and hyaluronic acid conferred either anti-adhesive and antibacterial properties to the surface of intraocular lenses, making them potentially useful for the prevention of endophthalmitis and posterior capsule opacification [161].

\subsubsection{Otitis and Sinusitis}

Lysozyme is expressed in the tube tympanic of mammals, playing an important role in protecting the middle ear and Eustachian tube.

Otitis media, or middle ear infection, is a common pediatrics disease and the increase in the resistance to antibiotics among the otitis media pathogens, such as Streptococcus pneumoniae, prompted the development of non-antibiotic approaches.

The effects of lysozyme on middle ear infections were studied on mice, in 2008 [162]. Mice have two lysozyme genes: lysozyme $\mathrm{M}$ expressed in macrophage, bone narrow, and lung tissue, and lysozyme $\mathrm{P}$, mainly expressed in the small intestine and at much lower levels in other cells/tissues. Wild-type mice and lysozyme $\mathrm{M}^{-/-}$mice were compared to verify if the lysozyme $\mathrm{M}$ depletion increased their susceptibility to pneumococcal otitis. A deficiency in lysozyme $\mathrm{M}$ led to an increased susceptibility to middle ear infection with S. pneumoniae and resulted in severe middle ear inflammation. The authors suggested that exogeneous lysozyme can be used as an adjuvant therapeutic agent for otitis media. Lysozyme and other antimicrobial proteins and peptides were investigated by the same research team, and their use was suggested for the treatment of otitis media and paranasal sinusitis $[124,163]$.

\subsubsection{Anti-Inflammatory Effects}

In addition to the antibacterial enzymatic activity, lysozyme displays anti-inflammatory effects: it is up-regulated in the gastrointestinal tract of patients affected by chronic inflammation as Bannet's esophagitis, chronic gastritis, coeliac disease, and colitis. The supplementation of the exogenous hen egg white lysozyme has a significant anti-inflammatory effect in the treatment of inflammatory bowel disease [164].

The anti-inflammatory effects of lysozyme against an extracellular mediator of vascular inflammatory disease, sepsis, was described in 2015 [165].

More recently, in 2019 [166], the anti-inflammatory effect of lysozyme was studied, investigating the perturbation of gene expression profiles induced by the in vitro supplementation of lysozyme $(15 \mu \mathrm{g} / \mathrm{mL}$ for $1 \mathrm{~h}$ or for $24 \mathrm{~h})$ in a monocyte cell line, a type of cell that interacts with lysozyme. The proteins in the cell line were identified and quantified by LC-MS/MS. The results showed that the anti-inflammatory activity of lysozyme was due to the mechanism of gene regulation involving the proteins of the inflammatory pathway, such as tumor necrosis factor alpha (TNF- $\alpha$ ) and interleukin 1 beta (IL-1 $\beta)$. 


\subsection{Lysozyme as Food Preservative}

Food spoilage is the result of chemical, physical, or microbiological modifications that renders the food unacceptable. Microbial food spoilage occurs due to the growth of microorganisms (bacteria, fungi, and yeasts) in or on the food, and it is also the cause of most food-borne illnesses.

To overcome these undesired effects, manufactures and producers employ multiple strategies for food preservation, which include chemical, biological, and physical treatments. Lysozyme, in place of traditional antibiotics, can be utilized to preserve food and beverages in much the same manner, with reduced side effects practically limited to triggering adverse allergic reactions in susceptible individuals. For this reason, its presence in foods and beverages in many countries required the inclusion of egg allergens in labeling, when present in the final product (see, for example, Regulation (EU) No 1169/2011 of the European Parliament and of the Council of 25 September 2011).

The use of lysozyme as a food additive is permitted in cheese, since it exerts an inhibitory effect against the growth of lactic acid bacteria involved in curd acidification and cheese ripening [167]. It also inhibits the growth of Clostridium tyrobutyricum that causes late blowing in hard and semi-hard cheese. In wine making, a maximum of $500 \mathrm{mg} / \mathrm{L}$ of lysozyme has been permitted, since 1996 (resolution OENO 10/97), because it helps to control malolactic fermentation by limiting lactic acid bacteria proliferation [168]. For unpasteurized beer, the concentration of $300 \mathrm{mg} / \mathrm{L}$ of lysozyme can reduce lactic acid beer spoilage bacteria, such as Pediococcus inopinatus, Lactobacillus brevis, Lactobacillus brevisimilis, and Lactobacillus lindneri [169].

To overcome the allergenic risks, due to the presence of lysozyme that can remain in food and beverages, different strategies were studied, including the immobilization through the Maillard reaction on different polysaccharides, to obtain films endowed with antimicrobial properties that can extend the shelf life of wrapped foods. For example, a bilayer edible film, based on chitosan and sodium alginate and incorporated with lysozyme, was demonstrated to be effective against fish spoilage bacteria, Pseudomonas fluorescens and Shewanella putrefaciens [170]; a lysozyme-chitosan composite film presented antimicrobial functions against both Gram-positive and Gram-negative representative bacteria (E. coli and S. faecalis) [171]; a lysozyme-dextran conjugate was effective against $S$. aureus and $E$. coli in a natural food system (cheese curd) [172]; a lysozyme-sodium alginate edible film was tested on two Gram-positive bacteria (i.e., Listeria innocua and Kocuria rhizophila) giving positive results [173]; lysozyme integrated into chitosan nanoparticles showed improved antibacterial activity against E. coli and B. subtilis [132,174]; and a chitosan composite film containing lysozyme-rectorite showed reduced mechanical properties $(-28 \%)$ in regard to the film containing only chitosan and enhanced antibacterial properties on E. coli and S. aureus [175]. With a different approach on foods already containing egg derivatives, lysozyme immobilized on a polysaccharide was added to the food, in order to improve its functional properties and to extend the shelf life, such as in the case of mayonnaise treated with lysozyme immobilized on Arabic gum [176]. The attempt to reduce the allergenicity of lysozyme-treated wine using a thermal or an enzymatic treatment was carried out without producing a convincing outcome [168].

Since lysozyme exhibited weak inhibitory effects against Gram-negative bacteria, when used alone, the practical application of free lysozyme as a food preservative was quite limited and many methods used to enhance the susceptibility of Gram-negative bacteria were attempted, namely the combined use with cinnamaldehyde [177]; acidic electrolyzed oxidizing water [178]; heat treatment and hydrogen peroxide associated with a packaging in a controlled atmosphere [179]; high hydrostatic pressure [180]; disodium ethylenediaminetetraacetate salt and ethylenediaminetetraacetic acid [181,182]; chitooligosaccharides [183]; chitosan-organic rectorite composites and negatively charged sodium alginate film-coated cellulose acetate mats [184]; EDTA in starch-based active food packaging film [185]; enterocin AS-48 [186]; and pomegranate peel extract [187]. The 
relevant data on the synergic uses of these substances with lysozyme are summarized in Table 1.

Table 1. Relevant data on the synergic uses of different substances with lysozyme, in order to enhance the susceptibility of Gram-negative bacteria.

\begin{tabular}{|c|c|c|c|}
\hline Combined Use with & Application/Claimed Use & $\begin{array}{c}\text { Antibiotic Activity Evaluated } \\
\text { Against/On }\end{array}$ & Refs. \\
\hline Cinnamaldehyde & $\begin{array}{l}\text { Storage of olive flounder } \\
\text { (Paralichthys olivaceus) } \\
\text { fillets/lowered total viable count }\end{array}$ & S. putrefaciens and P. fluorescens & [177] \\
\hline Acidic electrolyzed oxidizing water & $\begin{array}{l}\text { To prolong the shelf life of carp } \\
\text { fillets from a microbiological point } \\
\text { of view }\end{array}$ & $\begin{array}{l}\text { Total viable count, Enterobacteriaceae } \\
\text { count, and anaerobic mesophilic count }\end{array}$ & [178] \\
\hline $\begin{array}{l}\text { Heat treatment and dilution with } \\
\text { hydrogen peroxide associated with } \\
\text { packaging in a controlled } \\
\text { atmosphere }\end{array}$ & $\begin{array}{l}\text { To extend the shelf life of pork meat } \\
\text { by more than } 20 \% \text {, compared with } \\
\text { the control sample without } \\
\text { lysozyme }\end{array}$ & $\begin{array}{l}\text { Aerobic plate count, Enterobacteriaceae, } \\
\text { Pseudomonas spp., and lactic acid } \\
\text { bacteria }\end{array}$ & [179] \\
\hline High hydrostatic pressure & $\begin{array}{l}\text { Not significant enough to } \\
\text { differentiate lethality of lysozyme } \\
\text { without additives in cheeses made } \\
\text { from raw milk }\end{array}$ & B. cereus & [180] \\
\hline $\begin{array}{l}\text { Disodium } \\
\text { ethylenediaminetetraacetate salt }\end{array}$ & $\begin{array}{l}\text { Buffalo meat in refrigerated } \\
\text { conditions }\end{array}$ & $\begin{array}{l}\text { Total viable mesophilic count, total } \\
\text { viable psychrotrophic count, lactic acid } \\
\text { bacteria, Pseudomonas spp., and } B \text {. } \\
\text { thermosphacta }\end{array}$ & [181] \\
\hline Chitooligosaccharides & $\begin{array}{l}\text { The microbiological quality of } \\
\text { minced meat stored in refrigerated } \\
\text { conditions was improved }\end{array}$ & $\begin{array}{l}\text { Escherichia coli, Pseudomonas fluorescens, } \\
\text { Bacillus cereus, and Staphylococcus aureus }\end{array}$ & [183] \\
\hline $\begin{array}{l}\text { Ethylenediaminetetraacetic acid } \\
\text { disodium salt }\end{array}$ & $\begin{array}{l}\text { To reduce the growth of } Y \text {. } \\
\text { enterocolitica in orange beverages }\end{array}$ & Y. enterocolitica & [188] \\
\hline $\begin{array}{l}\text { Layer-by-layer chitosan-organic } \\
\text { rectorite composites and negative } \\
\text { charged sodium alginate. }\end{array}$ & $\begin{array}{l}\text { The sensory analysis and } \\
\text { physicochemical analysis applied to } \\
\text { assess the effects of layer-by-layer } \\
\text { film coating confirmed a higher } \\
\text { score for the packaged pork }\left(4^{\circ} \mathrm{C}\right. \\
\text { for } 21 \text { days) }\end{array}$ & E. coli and S. aureus & [184] \\
\hline $\begin{array}{l}\text { EDTA in anti-microbial } \\
\text { starch-based active food packaging } \\
\text { films }\end{array}$ & $\begin{array}{l}\text { Cooked rice with pulses/effective } \\
\text { to inhibit the growth of spoilage } \\
\text { microorganisms }\end{array}$ & $\begin{array}{l}\text { Contaminated from the open } \\
\text { environmental sources (mainly } \\
\text { Gram-negative cocci) }\end{array}$ & [185] \\
\hline EDTA & $\begin{array}{l}\text { A different lysozyme activity } \\
\text { against the tested microorganisms } \\
\text { was observed, increasing the ratio } \\
\text { of lysozyme/EDTA from } 11.14: 8.14 \\
\mathrm{mg} / \mathrm{mL} \text { to } 11.14: 14.14 \mathrm{mg} / \mathrm{mL} \text {. }\end{array}$ & $\begin{array}{l}\text { Micrococcus lysodeikticus and Escherichia } \\
\text { coli }\end{array}$ & [182] \\
\hline Enterocin AS-48 & $\begin{array}{l}\text { Synergy confirmed in liquid whole } \\
\text { eggs, egg whites, and egg yolks, at } \\
4{ }^{\circ} \mathrm{C} \text { and } 28{ }^{\circ} \mathrm{C}\end{array}$ & B. cereus and S. aureus & [186] \\
\hline Pomegranate peel extract & $\begin{array}{l}\text { To maintain the quality of mackerel } \\
\text { fillets wrapped with } \\
\text { gelatin/polycaprolactone } \\
\text { composite film and to prolong the } \\
\text { shelf life of the product }\end{array}$ & $\begin{array}{l}\text { Total mesophilic counts and } \\
\text { psychrotrophic bacteria counts }\end{array}$ & [187] \\
\hline
\end{tabular}




\subsection{Feed Uses of Lysozyme}

Antibiotics have been used for many years in animal production. They are included in animal feeds at subtherapeutic levels to improve growth rate and feed efficiency, for disease prophylaxis, and at higher doses, for disease therapy. Even though antibiotics have been used by growers as effective supplements, their use, nowadays, as feed additives in animal production is strongly limited or banned on the basis of the "precautionary principle" that resistance selected in animals can be transmitted to humans to the detriment of their health [189]. Historically, the first banned antibiotic for animal use was avoparcin, in 1997, followed by bacitracin, spiramycin, tylosin, and virginiamycin, in 1999 [190]. To manage this problem, it is necessary to improve the biosecurity by avoiding, if possible, the use of traditional antibiotics and looking for safer alternatives, such as dietary supplements, including probiotics, prebiotics, and natural antibiotics, including lysozyme, which are adequate for animal production.

Several studies explored the advantages of using lysozyme alone, as a dimer or in association with other proteins, antibiotics, or EDTA, for feed uses in poultry, pigs, cows, fish, and rabbits, and for crop protection.

These studies investigated the influence of the dietary supplementation of lysozyme on growth performance (body weight (BW), average daily gain (ADG), and daily food intake (ADFI)) and the changes of microbiota in treated animals.

\subsubsection{Poultry}

In a 2020 study, the influence of dietary supplementation with some antibiotic alternatives, including lysozyme, on the growth performance, intestinal barrier, and immunity of lipopolysaccharide-challenged chicks was investigated. The evaluation of lysozyme as an alternative antibiotic aureomycin in growing yellow-feathered chicks was carried out. The results showed that the dietary addition of lysozyme $(500 \mathrm{mg} / \mathrm{Kg})$ had a comparable effect to the antibiotic treatment on the jejunal barrier and on the immunity of yellowfeathered chicks aged from 4-24 days. From a biochemical point of view, the lysozyme treatment reduced diamine oxidase activity and the inflammatory mediators in plasma, jejunal mucosa, spleen, and thymus; increased the content of immunoglobulin in plasma and jejunal mucosa; and decreased the gene expression of inducible nitric oxide synthase and cyclooxygenase 2 in jejunal mucosa. This lysozyme treatment was, however, ineffective to retrieve the normal BW, ADG, and ADFI of the chicks after liposaccharide treatment [191]. In another paper, the chicks were fed a starter (1-21 days) and a grower (22-42 days) diet supplemented with 0 (control), 40, 100, or $200 \mathrm{ppm}$ lysozyme, or $400 \mathrm{ppm}$ flavomycin as an antibiotic control for 6 weeks. Lysozyme administration did not contribute significantly to the growth of the broiler chickens. No significant differences in the diversity and composition of the bacterial and fungal flora in the cecal microbiota of chickens in the different diet groups were found. However, lysozyme supplementation led to a significant enrichment of genes involved in the synthesis/degradation of bacterial outer membranes and cell walls, cross-cell substrate transport, and carbohydrate metabolic processes, thus possibly promoting the cecal microbiota carbon and energy metabolism [192].

Necrotic enteritis is a worldwide poultry disease caused by the overgrowth of Clostridium perfringens in the small intestine. The addition of exogenous lysozyme (40 mg lysozyme $/ \mathrm{kg}$ ) to the diet of chickens significantly reduced the concentration of C. perfringens in the ileum, and the intestinal lesion scores inhibited the overgrowth of E. coli and Lactobacillus in the ileum and intestinal bacteria translocation to the spleen, whilst improved intestinal lysozyme activity in the duodenum and the feed conversion ratio of chickens. These findings suggest that the exogenous lysozyme can decrease $C$. perfringens colonization and improve the intestinal barrier in chickens [193]. In another trial, the effect of a feed of $100 \mathrm{ppm}$ lysozyme with EDTA $(1 / 4 w / w)$ on the growth performance and intestinal microbiota of broiler chickens in each period of the growth cycle (total 35 days) was evaluated. The inclusion of virginiamycin or lysozyme in the broiler diets, at different periods during their growth, had no effects on their daily weight gain (DWG), feed consumption, or 
feed conversion rate (FCR), in both of the new litter and used litter trials. Moreover, the number of aerobic bacteria, anaerobic bacteria, coliforms, E.coli, lactic acid bacteria, and C. perfringens in the ileum was not influenced by the inclusion of the antibiotic or lysozyme in the diets [194].

In poultry and swine production, the administration of lysozyme through water or feed in association with nisin, albumen, and sequestering agents, such as EDTA, citric acid, or chitosane, was effective to inhibit the growth, diseases, and epidemiology effects caused by C. perfringens, E. coli, Salmonella typhimurium, and Salmonella Mbandaka in the gut of livestock. Therefore, it is useful in the treatment of necrotic enteritis, C. perfringens enteritis, and diarrheal disease [195]. A recent patent application claimed a composition containing rhLys (10-20\%), Bacillus coagulans spore powder (20-30\%), Lactobacillus plantarum (5-15\%), fructooligosaccharide (5-15\%), and auxiliary materials as a poultry and livestock feed additive. This composition, according to the authors, can replace antibiotics to be mixed with feed or water, as a livestock growth promoter; it can also be used to prevent and treat common animal diseases and improve immunity and survival rates [196].

\subsubsection{Pigs}

A review on lysozyme as an alternative to growth promoting antibiotics in swine production was published in 2015 [197] and, more recently, in 2019. In 2021, two metaanalyses focused on the evaluation of the antibacterial activity and the impact on the performance of weaned pigs of potential dietary feed additives, including lysozyme, were published [198,199]. The use of lysozyme, as a food additive at a dosage comprises between $0.01 \%$ and $0.2 \%$, showed an ADG of $28 \mathrm{~g}$ higher, with respect to the negative control group (normal feed), while no significant difference with the positive control group was observed (treated with antibiotics). A feed reduced by $52 \mathrm{~g}$ was required in the treatment group, compared to the negative control group, to gain $1 \mathrm{~kg}$ of bodyweight, while no significant difference with the positive control group was observed.

The results of a clinical trial carried out to investigate the response of piglets receiving a water-soluble lysozyme/EDTA mixture (known by the trade name of Entegard ${ }^{\circledR}, \mathrm{EG}$, Neova Technology Inc., Abbotsford, BC, Canada), delivered in the drinking water at concentrations of $0.1 \%$ and $0.2 \%$, after an oral challenge with enterotoxigenic E. coli (ETEC), compared with a control with no additives or antibiotics $(2.5 \mathrm{~g} / \mathrm{kg}$ of an antibiotic feed with chlortetracycline, sulfamethazine, and penicillin), confirmed that this treatment did not influence the growth performance throughout the study. However, better intestinal growth and development, as well as decreased ETEC counts in the intestinal mucosa and serum proinflammatory cytokines, suggested that lysozyme/EDTA could maintain gut health and function in piglets commensurate with antibiotics. In this paper, it was observed that, in the largest tested dose, lysozyme/EDTA seemed to have a dramatic effect on proinflammatory cytokines, but had a minimal or no effect on the other response criteria [200]. The results of a similar test carried out on 10-day-old pigs that included a feed supplement with lysozyme/EDTA (100 mg/L water solution), in comparison with traditional antibiotics (i.e., neomycin and oxytetracycline, $16 \mathrm{mg} / \mathrm{kg}$ of diet), to evaluate the growth performance and small intestinal morphology after a Campylobacter infection confirmed that lysozyme/EDTA was a suitable alternative to antibiotics for 10-day-old pigs consuming manufactured liquid diets. More significantly, this work confirmed that pigs gained a weight of $334 \pm 12 \mathrm{~g} /$ day from 0 to 7 days of treatment, regardless of dietary treatment. However, from 7 to 14 days, pigs fed with the lysozyme/EDTA and antibiotic treated diets gained BW at a greater rate, compared with pigs fed with the control diet, which resulted in an overall faster ADG from 0 to $14 \mathrm{~d}$ (402 \pm 12 and $422 \pm 14 \mathrm{~g} /$ day vs. $364 \pm 14 \mathrm{~g} /$ day, respectively) [201]. The outcome that lysozyme improved the growth rate and can be effective for pathogen control, when fed in nursery diet, was confirmed by other papers in which lysozyme was administered in the diet at a concentration of 100-120 mg/ kg [202-205]. Oliver et al. observed changes in small intestinal morphology (in the jejunum, the villi height to crypt depth ratio increased by $72 \%$ ) in nursery pigs consuming lysozyme. It remains to be seen whether the intestinal 
changes were mechanistically responsible for the improved feed conversion. Further studies confirmed the above assumptions and, in addition, showed that lysozyme, as well as antibiotics, increased protein deposition at the expense of lipid accretion, since the immune response in pigs redirected nutrients away from growth and toward the immune system and ameliorated the effects of a chronic immune challenge [206].

A study on the variations in the gut microbiota of sows, serum immunity and breast milk metabolite profiles mediated by lysozyme supplementation was published, in 2018 [207]. Sows that received $1.0 \mathrm{~kg} / \mathrm{t}$ of lysozyme treatment showed significant variation that was determined by the high-throughput sequencing of the microbial 16S rRNA genes, in microbial diversity: Spirochaetes, Euryarchaeota and Actinobacteria significantly increased, while Firmicutes showed a remarkable reduction compared with control. Different to the above cited works, a paper published in 2021 focused on the evaluation of the efficacy of lysozyme on the growth performance, nutrient digestibility, excreta microflora population, and blood profiles of weanling pigs under $E$. coli challenge, but showed unsuccessful results since lysozyme did not improve the growth performance (ADG) after inoculation [208]. The authors suggest that the different outcome of their results can be due to the different sources of lysozyme, different species of E. coli, or to the presence of a direct $E$. coli K88 (the strain they used) challenge.

In 2018, a paper was published evaluating the protective effect against the enterotoxigenic E. coli (ETEC) infection of neonatal piglets fed with milk from transgenic pigs that express high levels of rhLys (about $1300.7 \pm 126.7 \mathrm{mg} / \mathrm{L}$ ), compared to neonatal piglets fed with milk from wild-type sows. The observed protective effect of rhLys (i.e., facilitated faster recovery from infection and decreased mortality and morbidity following an ETEC oral inoculation or infection acquired by contact exposure) was associated with the enrichment of intestinal bacteria, such as Lactobacillus, that improve gut health and the enhancement of the mucosal IgA response to the ETEC-induced diarrhea [209]. The simultaneous expression of hLys and human lactoferrin (hLF) in bi-transgenic pigs, and the evaluation of the milk's antibacterial ability, were evaluated. The results confirmed that pig milk containing hLF and hLys (at $6.5 \mathrm{~g} / \mathrm{L}$ and $1.1 \mathrm{mg} / \mathrm{L}$, respectively) had synergistic antimicrobial activity, as determined using the M. lysodeikticus test [210].

\subsubsection{Cows}

The utilization of lysozyme as an alternative antibiotic in the veterinary field was explored in several patents and papers, particularly for the treatment/prevention of mastitis and in combination with other substances as antiviral to treat the bovine viral diarrhea virus (BVDV). In 2008, a patent application about a topical composition containing lysozyme, serratiopeptidase, Oscimum sanctum, and Azadirechta, for the prevention and/or treatment of mastitis and metritis in mammals, was filed [211]. In 2021, another biological disinfectant preparation for preventing mastitis in dairy cows, which included bactericidal effective amounts of lysostaphin $(0.1-10 \%)$, lysozyme $(1-40 \%)$, and other auxiliary components, was patent protected [212]. A recent study confirmed that the effectiveness of antibiotic treatment combined with lysozyme dimer was $58.3 \%$, and comparable with other methods of supportive therapy. In this study, the use of lysozyme dimer $(5.0 / 10 \mathrm{~mL}$; Lydium-KLP, Nika Health Products Sp. z o o, Śmigiel, Poland) at a dose of $0.02 \mathrm{mg} / \mathrm{kg}$ increased the therapeutic efficiency by $6.7 \%$, compared with the control mastitis group. However, this difference was considered by the same authors as not statistically significant [213]. As an alternative approach, a gene therapy strategy for treating bovine mastitis was developed in 2006: a new mammary-specific vector containing hLys, cDNA, and the kanamycin resistance gene for intramammary expression and clinical studies was constructed. The clinical studies showed that the injection of the diseased quarters twice with the p215C3LYZ vector had an overt therapeutic effect on bovine mastitis (in particular, clinical mastitis), including the disappearance of symptoms, a significant improvement in the California mastitis test score, and a reasonably high microbiological cure rate [214]. 
In another paper, the antibacterial efficacy of an experimental formula containing $15 \%$ condensed donkey milk (lysozyme content $825 \mathrm{mg} / \mathrm{L}$ ) for washing cows' udders before milking, was evaluated. The antimicrobial activity of condensed milk was firstly evaluated in vitro, using the disk diffusion method on the following microorganisms: Bacillus megaterium, Bacillus mojavensis, Clavibacter michiganensis, and Clostridium tyrobutyricum. These tests were compared with the effects of two antibiotics, ampicillin $(100 \mathrm{mg} / \mathrm{mL})$ and kanamycin $(50 \mathrm{mg} / \mathrm{mL})$, and a commercial pre-dipping formula, showing that the inhibitory activity of lysozyme from donkey milk on all the considered microorganisms was higher than that of the commercial product and similar to that of the two antibiotics [215]. Bovine viral diarrhea virus (BVDV), an enveloped, single-stranded, positive-sense RNA virus from the Flaviviridae family, is a globally distributed bovine pathogen. In 2019, the antiviral effect of naturally occurring proteins and peptides, such as bovine lactoferrin, chicken egg lysozyme, and nisin from Lactococcus lactis, used both individually and in combination, was evaluated in vitro, against the cytopathic NADL strain of BVDV. The study demonstrated that nisin and lysozyme were effective at later stages of the infection, and the intensity of their effect did not diminish with time. Nisin + lactoferrin and lysozyme + lactoferrin combinations demonstrated stronger antiviral effects than the single substances [216].

\subsubsection{Fish}

In aquaculture, the accumulation of antibiotics resulted in the development of resistance among bacterial pathogens, and the possibility to utilize lysozyme instead of traditional antibiotics is an active and growing research field. In a 2015 study, a novel antimicrobial peptide, derived from the goose type lysozyme (LyzG), was identified from the cDNA library of freshwater fish, Channa striatus (Cs). The identified lysozyme cDNA contains 585 nucleotides, which encodes a protein of 194 amino acids. CsLyzG was closely related to Siniperca chuatsi with $92.8 \%$ homology. Two antimicrobial peptides, IK12 and TS10, were identified from CsLyzG and synthesized. The antibiogram showed that IK12 was active against Salmonella enterica and induced a loss of cell viability in the bacterial pathogen [217]. A 2016 patent application protected a feed composition for aquatic animals, especially for cold water fish (for instance, salmon, bream, and bass) and for warm water fish (for instance, carp, tilapia, and catfish) containing natural active substances (alphapinene, alpha-terpineol, cinnamaldehyde, dihydroeugenol, eugenol, meta-cresol, and terpinolene) in combination with a polypeptide having lysozyme activity. The polypeptides having lysozyme activity were isolated from fungus phylum Ascomycota and subphylum Pezizomycotina, and the amino acid sequence was identified. It was observed that this feed additive protected fish against infections caused by pathogenic microorganisms, Grampositive microorganisms in particular, and to increase the feed conversion rate (FCR) and ADG [218]. In another study, the potential effects of dietary garlic supplementation on the health status of common carp (Cyprinus carpio) exposed to ambient ammonia toxicity was investigated. Indeed, high stocking density, in addition to un-eaten feed that decomposes in water, can lead to the accumulation of organic matter and toxic inorganic nitrogen, which can reach an unsafe level and threaten fish health. In this protocol, the fish were fed with either 0 (control), $0.5,1$, or $1.5 \%$ levels of garlic for 35 days, then challenged with $0.5 \mathrm{mg} / \mathrm{L}$ of ambient unionized ammonia-nitrogen for $3 \mathrm{~h}$. The results of this study showed that garlic administration mitigated the adverse effects of ammonia exposure characterized by improving the antioxidant activities and decreasing plasma malondialdehyde, plasma glucose, and cortisol levels, and alanine transaminase; alkaline phosphatase; aspartate transaminase; and glutathione peroxidase activities. Moreover, it significantly increased plasma catalase, lysozyme, bactericidal activities, and Ig levels, but had no effect on the plasma superoxide dismutase activity [219]. The prospective use of jaggery (a concentrated product of cane juice) as a potential carbon source and its influence on water quality, growth performance, innate immunity, serum bactericidal capacity, and disease resistance to Aeromonas hydrophila was investigated in Oreochromis niloticus. It was demonstrated 
that the use of this carbon source had a pronounced effect on hematological and growth performance parameters in comparison with the control. Moreover, serum antioxidants, lysozyme, protease, antiprotease, and bactericidal capacity were significantly increased in the treated groups in a dose-dependent manner [220].

\subsubsection{Rabbits}

A comparative study on the effects of dietary hen egg lysozyme $(100 \mathrm{mg} / \mathrm{kg})$ and /or zinc bacitracin antibiotics (ZnBs) on the productivity and health conditions of rabbits was carried out in 2021. After eight weeks, the final weight and body weight gain of rabbits that were fed dietary lysozyme and $\mathrm{ZnB}$ additives were meaningfully increased and the feed conversion ratio was markedly decreased. In addition to the enhancement of the growth performance, the rabbits treated with lysozyme and those treated with $\mathrm{ZnB}$ showed significantly lower populations of Clostridium spp. and E. coli compared with the control; whereas, the counts of Lactobacillus and total bacteria were meaningfully increased in the intestines of rabbits treated with lysozyme and $\mathrm{ZnB}$. The levels of total protein, globulin, creatinine, urea, ALT, and AST, and the gene expressions of the liver superoxide dismutase and glutathione peroxidase of the treated rabbits were also reported [221].

\subsection{Crop Protection}

Lysozymes are naturally present in various plants in farm animal materials used for food and feed preparation, and for the prevention and treatment of some microbial infections, including the possibility to substitute conventional bactericides and biopesticides for crop protection. Using recombinant DNA technology, the microbial gene coding for the bactericidal T4 lysozyme (endo acetylmuramidase) was integrated into the genome of potato plants. Laboratory and field tests demonstrated the expression of the gene during plant growth and a markedly decreased infection of plants and tubers by the phytopathogenic bacterium Erwinia carotovora ssp. atroseptica. Environmental testing did not indicate any adverse effects of the transgenic plants on the soil microbiota, including plant-beneficial bacteria [222].

Lysobacter enzymogenes LE16 broth culture unheated self-digestive solution, or heated at $100{ }^{\circ} \mathrm{C}$ for $30 \mathrm{~min}$, or stored for $12 \mathrm{months}$ at room temperature, were prepared to study their potential as biocontrol agents. This bacterium produced protease, phosphatase, lysozyme, and siderophores in pure culture, as well as 12 secondary metabolites, including novel antibiotics lysobactin, WAP-8294A2, and mupirocin determined and based on the antiSMASH 5.0.0 BLAST database. A poison plate assay was carried out to test the antagonistic activities of these solutions against $S$. aureus, P. syringae pv. tabaci, and numerous plant pathogenic fungi, and oomycetes, including Colletotrichum gloeosporioides; Penicillium italicum; Alternaria alternate; Rhizoctonia solani; Didymella bryoniae; Sclerotinia sclerotiorum; Phytophthora nicotianae; and Phytophthora capsici. These experiments showed that the unheated self-digested Lysobacter enzymogenes LE16 broth culture was highly effective in controlling pepper blight disease, which is caused by P. capsici. Compared with pathogenonly inoculation, the application of unheated self-digestive solutions of L. enzymogenes LE16 to the soil, in preventive or curative treatments, significantly reduced the disease incidence and the index with a relatively high control efficacy of $86-93 \%$ [223].

In a study conducted in 2006, the effect of genetically modified (GM) potatoes producing anti-bacterial agents was investigated, such as cecropin/attacin and T4 lysozyme on the diversity and functional abilities of bacteria colonizing the intercellular spaces and vascular tissues (endosphere) of potato plants. These GM potatoes can offer effective future pathogen control strategies, particularly for the treatment of blackleg and soft rot disease of potatoes (Solanum tuberosum L.), mainly caused by the bacterial pathogen Erwinia carotovora ssp. atrospetica (Eca). In order to compare GM-related variations with impacts caused by changing environmental conditions, potatoes were cultivated in two different soil types, and challenged with the pathogen Eca. The endophytic diversity was assessed by $16 \mathrm{~S}$ rRNA-based terminal-restriction fragment length polymorphism (T-RFLP) analysis. The 
result of this study confirmed that the impact of both genetic modification types was minor or comparable with the variations caused by plant genotype, vegetation stage, pathogen exposure, and soil type [224].

The control of fire blight, whose causal pathogen is the Gram-negative bacterium $E$. amylovora, has been mainly attempted by spraying the antibiotics streptomycin and oxolinic acid. Moreover, copper sprays or chemical resistance inducers, such as prohexadione $\mathrm{Ca}$ (Apogee) can be alternatively used. Alternative biological control was also tested using antagonistic bacteria (P. fluorescens strain A506), bacteriophages; yeasts were also used with some success to interfere with E. amylovora populations. In a 2006 paper, a viral lysozyme from the E. amylovora phage $\varphi$ Ea1h affecting Gram-negative bacteria, such as the fire blight pathogen, was characterized. A lysozyme gene from the E. amylovora phage $\varphi E a 1 \mathrm{~h}$ was cloned and expressed in E. coli, and the protein activity compared with lysozyme from the E. coli phage T4. $\varphi$ Ea1h lysozyme lysates strongly affected E. amylovora cells. The protein displayed enzymatic and antibacterial activities. Pear slices soaked in $\varphi$ Ea1h lysozyme-containing cell lysates showed reduced fire blight symptoms after inoculation with E. amylovora [225]. An alternative approach to treat the infection by E. amylovora using a combination of lysozyme and of a synthetic peptide derivative was described in a paper published in 2017. BP100, a linear undecapeptide (KKLFKKILKYL-NH ${ }_{2}$ ), has been reported to be effective against $E$. amylovora infections in apple and pear flowers. However, peptide concentrations necessary for the control of fire blight disease were 10 to 50 times higher than the minimal inhibitory concentration (MIC). This decrease in the activity in plants has been attributed to the inactivation by certain plant compounds or structures, or to their degradation by proteases from plant tissues or epiphytic microorganisms. The combination of BP100 with lysozyme produces a synergistic effect. It was observed that while BP100 or lysozyme alone, at the concentrations tested, were not active, at $1.0 \mu \mathrm{M}$ BP100 the effect of the addition of lysozyme was only observed at $0.5 \mathrm{mg} / \mathrm{mL}$, and at $2.5 \mu \mathrm{M}$ the effect on the growth inhibition was significant in all lysozyme concentrations. The significant increase in the antimicrobial activity against E. amylovora was associated to the increase in cell membrane damage and to the reduction of cell metabolism. The combination of BP100 with lysozyme reduced the time required to achieve cell death and the MIC, and increased the activity of BP100 in the presence of leaf extracts, even when the peptide was applied at low doses [226].

\section{Synergistic Activity of Lysozyme}

A synergistic interaction is defined as the observation of a combination effect that is greater than the sum of the effects of two independently administered agents, whereas additive interactions are when the combined effect is equal to the sum of the individual effects.

\subsection{Antimicrobial Peptides (AMPs)}

After the discovery of lysozyme, various types of molecules with antibiotic activity have been isolated from animals, insects, plants, and bacteria, among those the AMPs play an important role. The mammalian innate AMPs are essential for the protection of skin and other organs, but they also control physiological functions, such as inflammation, angiogenesis, and wound healing [227].

These peptides are defined as antimicrobial since they have abroad spectra of activity, including the ability to kill Gram-negative and Gram-positive bacteria, fungi, parasites, cancer cells, and even viruses, such as HIV and the herpes simplex virus. These peptides are stored in granules of phagocytic cells and are expressed and released at the epithelial surface and in a site of inflammation. Hancock and Scott, in two reviews published in $2000[228,229]$, described how they can present the synergy with lysozyme disrupting the outer membrane that is the barrier that excludes lysozyme from the peptidoglycan. Most of the AMPs are cationic and they can adopt an amphiphilic conformation. As a result of these features, they can interact with the negatively charged compounds on the surface of bacterial cells and insert into the lipid bilayers. 
The human lysozyme was reported by Hancock to show a good synergy with the AMP protegrin against Enterococcus faecalis: indeed the MICs of protegrin and lysozyme were lowered from 16 and $6 \mu \mathrm{g} / \mathrm{mL}$, when used alone, to 4 and $0.39 \mu \mathrm{g} / \mathrm{mL}$, respectively, in combination [230]. The combination of human lysozyme with six different AMPs against $P$. aeruginosa was recently examined and the authors discovered that some AMPs manifest antagonistic interactions with hLys, in contrast to prior reports [231]. These results, according to the authors, must be considered for the future development of lysozyme and AMP combination therapies.

As discussed in the previous section considering crop protection, the combination of the synthetic undecapeptide BP100 with lysozyme is another example of the synergistic application of lysozyme for the treatment of fire blight [22,226].

The presence of a peptide, inhibiting the growth of Salmonella enterica, Aeromonas salmonicida, and Vibrio anguillarum, was identified in salmon mucus and blood. This peptide correlates with the increase in lysozyme activity following a disease challenge. Two synthetic peptides, homologous of the identified peptides, were prepared and their antimicrobial assayed. The two artificial peptides were devoid of activity against $V$. anguillarum and $A$. salmonicida, but were able to potentiate lysozyme, proving support to the synergy between lysozyme and the identified peptide [232].

Bacteriocin AS-48 is an AMP produced by E. faecalis and is active against several Grampositive bacteria. This AMP is a ribosomal synthesized and post-translationally modified peptide (70 amino acid residues) which undergoes head-to-tail cyclization, affording a cyclic molecule. In a 2018 article [233], its activity against Mycobacterium tuberculosis, the agent that causes tuberculosis, was demonstrated. The activity of AS-48 alone and in combination with lysozyme or with ethambutol, a first-line drug used in the treatment of tuberculosis, was studied. The test showed that lysozyme strongly synergized with AS-48 in in vitro cultures, whereas no synergistic effect was observed in the intracellular model of infections. The authors suggested that either lysozyme could not enter the macrophages and reach the intracellular bacteria, or that the enzyme might have been degraded by the macrophage. A strong synergy was found in both systems with ethambutol.

\subsection{Lactoferrin}

Human lactoferrin is a mucosal glycoprotein present in milk and in secretions, such as saliva, tears, serum, and neutrophiles granules. It is endowed with bacteriostatic and antimicrobial activities. The bacteriostatic effect is due to its ability to sequester iron, an essential ion for bacterial growth. The iron-free molecules of lactoferrin (ALF), when they undergo proteolysis, produce cationic peptides (lactoferricins) that can destabilize microbial membranes. The alteration of the permeability of the external membrane due to lactoferrin can facilitate the action of lysozyme on the peptidoglycan [234].

This already known synergistic action was investigated in 2015 [235] against Streptococcus pneumoniae, a colonizer of the nasopharynx of healthy children and adults, from where it can spread to lungs, meninges, and blood, leading to pneumonia, meningitis, or septicemia. Since lysozyme is a protein present at the mucosal sites, the potential synergistic effect with ALF was examined. The results showed that the combined effect of ALF and lysozyme was significantly higher than that of each protein, alone, for one of pneumococci strains examined. In other cases, the combination was not statistically more effective. Synergistic or additive killing by antimicrobial agents, including lactoferrin present in the human airway surface liquid, was investigated in 2000 [236]. The authors examined the combination of lysozyme with lactoferrin and the secretory leucocyte protease inhibitor (SLP1). The triple combination of lysozyme, lactoferrin, and SLP1 showed a greater synergy.

\subsection{EDTA}

Ethylenediaminetetraacetate (EDTA) has been used in several food products as a chelating agent to prevent oxidation. Chelating property to divalent cations like $\mathrm{Ca}^{2+}$ and $\mathrm{Mg}^{2+}$ is responsible for its antibacterial activity. Indeed, EDTA inhibits the growth of mi- 
croorganisms by depriving $\mathrm{Mg}^{2+}, \mathrm{Ca}^{2+}$, and $\mathrm{Fe}^{2+}$, which are essential for microbial growth. Furthermore, chelating agents contribute to the detachment of cells from the biofilm and to the killing of biofilm-producing microorganisms by depriving $\mathrm{Mg}^{2+}$ associated with lipopolysaccharides (LPS).

The works of Boland et al. $[237,238]$ demonstrated that the addition of EDTA enhanced inhibitory effect of lysozymes on strains of $E$. coli. The level of inhibition achieved with the addition of EDTA was 10 times as high as that achieved, in an equal concentration, with disodium pyrophosphate (DSPP) and pentasodium tripolyphosphate (PSTPP). DSPP and PSTPP were chosen as potential EDTA replacement chelators since they are negatively charged polyanions that form complexes with cations, such as copper, calcium, iron, zinc, and magnesium. Even if each lysozyme-chelator combination was effective, the concentrations of phosphate required to increase the lysozyme activity against $E$. coli were higher than the EDTA concentrations showing the same effect. The same authors [237] also studied the effect of different concentrations of mono-, di-, and trivalent cations on the antimicrobial effect of lysozyme-EDTA combinations. Calcium and magnesium resulted in the production of important ions for the reversal of lysozyme-chelator activity against E. coli strains, probably due to their role in the stability and structure of the LPS layer. Iron was effective in neutralizing lysozyme-chelator inhibition, probably because of its manifold functions and binding constants to chelators. Sodium and potassium showed a variable- and strain-dependent behavior. The study demonstrated that the efficacy of the lysozyme-chelator combination depended on the composition of the food to be protected.

According to a 2004 study [239], the addition of EDTA enhanced lysozyme activity against Listeria monocytogenes, while lysozyme alone inhibited the growth of L. monocytogenes Scott A, but did not inhibit growth of other L. monocytogenes strains. In the same work, the enhancement of lysozyme activity against $E$. coli by the addition of EDTA was also described, and the results were in agreement with the results of Boland et al. [237,238].

\subsection{Antibiotics}

The rapidly growing resistance of pathogenic bacteria to conventional antibiotics prompted the continuous research of new drugs or combinations of conventional antibiotics with new candidates. Antimicrobial peptides and proteins of the innate immune system constitute a possible approach.

In this context, an Indian team studied the combination effect of nine antibiotics with lysozyme and serratiopeptidase against six different bacterial cultures. While the results for the combination with serratiopeptidase were encouraging, the combination of lysozyme and fluoroquinolone gatifloxacin (the more active antibiotic when compared to the other antibiotics in all the cultures) was ineffective [240]. More recently, other fluoroquinolones, in combination with lysozyme, were the subject of DFT calculation and docking, to study their interaction with lysozyme. In 2018, ciprofloxacin and levofloxacin were investigated in antimicrobial assays and an antagonistic effect of lysozyme in an acid medium was evidenced [241].

In 2017, the location of different prototrophic forms of norfloxacin in lysozyme were examined with molecular docking simulations [242]. An analogous study was recently carried out to investigate the interaction between lysozyme and cephalosporin ceftazidime, by means of DFT calculations and docking [243]. The article did not report any antimicrobial activity data.

The antimicrobial activity of the combination of rhLys and tobramycin against $P$ seudomonas aeruginosa was assayed in a hamster model, in vitro [244]. Tobramycin is a potentially hazardous antibiotic, usually delivered by nebulization. The authors planned to study the combined aerosol delivery of both agents to verify if the addition of rhLys can lower the dose of the drugs and, therefore, reduce the harmful effect and improve patient outcomes. Hamsters instilled with $P$. aeruginosa were treated with an aerosol containing $1 \%$ rhLys, $3 \mu \mathrm{g}$ tobramycin, or both agents. To identify the contribution of rhLys to anti-bactericidal activity, the amount of tobramycin used in the experiments was equivalent to $1 \%$ of the 
standard dosage. The results showed an improvement to all examined parameters in the animals treated with both components, compared to those receiving rhLys or tobramycin alone. Pseudomonas aeruginosa incubated in vitro with both rhLys and tobramycin showed less viability than those treated with either agent alone.

$P$. aeruginosa, a cause of nosocomial infections and of chronic respiratory infections in patients with cystic fibrosis, was also the object of a study aimed to improve the modest basal effect of lysozyme (from egg whites) by subinhibitory doses of colistin, an antibiotic of the polymyxin family and active as a permeabilizing agent $[245,246]$. P. aeruginosa has an outstanding capacity for the development of antibiotic resistance through the chromosomal mutations of factors linked to peptidoglycan recycling, which frequently causes resistance to the antipseudomonal $\beta$-Lactams. The synergy between lysozyme and colistin, due to their action on the cell wall, is shown in Table 2.

Table 2. Susceptibility to colistin and lysozyme, and the combined treatment (lysozyme + colistin) of two strains of Pseudomonas aeruginosa (PAO1 and PA14).

\begin{tabular}{|c|c|c|c|c|}
\hline \multirow[b]{2}{*}{ Strain } & \multirow[b]{2}{*}{ Colistin MIC $(\mu \mathrm{g} / \mathrm{mL})$} & \multicolumn{3}{|c|}{ Percentage of Bacterial Survival after Each Treatment ${ }^{\text {a }}$} \\
\hline & & Colistin $(0.1 \mu \mathrm{g} / \mathrm{mL})$ & Lysozyme $(25 \mu \mathrm{g} / \mathrm{mL})$ & $\begin{array}{c}\text { Lysozyme }+ \text { Colistin }(25+0.1 \\
\mu \mathrm{g} / \mathrm{mL})\end{array}$ \\
\hline PAO1 & 0.75 & $45.3 \pm 11.2$ & $35.9 \pm 8.0$ & $4.1 \pm 1.3$ \\
\hline PA14 & 0.25 & $19.1 \pm 3.9$ & $52.3 \pm 10.2$ & $3.0 \pm 0.62$ \\
\hline
\end{tabular}

${ }^{\text {a }}$ Percentage of survival after each treatment in respect to the initial inoculum. PAO1 and PA14 survival percentages in the lysozyme assay buffer alone were between $80-90 \%$ after incubation.

Bactericidal synergism between daptomycin, a lipopeptide antibiotic, and Cpl-1, the bacteriophage Cp-1 lysozyme, against Streptococcus pneumoniae was documented both in vitro and in a mouse model [247]. Mice were treated intraperitoneally with an extremely virulent serotype of S. pneumoniae. Subtherapeutic doses of daptomycin $(0.4 \mathrm{mg} / \mathrm{Kg})$ and Cpl-1 $(0.4 \mathrm{mg} / \mathrm{Kg}$ and $0.1 \mathrm{mg} / \mathrm{Kg})$ were administered either alone or in combination, $1 \mathrm{~h}$ after the bacterial challenge. Daptomycin, in combination with lysozyme, increased the percentage of surviving mice on day $7(80 \%)$ compared with the untreated control $(0 \%)$, daptomycin or Cpl-1 monotherapy (35\% and 0\%, respectively).

Metronidazole is an antibiotic that has been used against Helicobacter pylori, a human pathogen that plays an important role in peptic ulcers and chronic gastritis. The reduced efficacy of metronidazole, due to the onset of resistance in $H$. pylori, can be overcome by increasing the doses and prolonging the duration of therapy. In order to improve its activity and lower the resistant mutant, a prevention therapy using a combination of metronidazole with hLys was studied [248]. The choice of lysozyme, even if $H$. pylori is resistant to this enzyme, was explained by the authors with its ability to modify the permeability of bacterial cells and to promote the antibiotic adsorption. Its effect on the outer and inner membranes was detected by a fluorescent probe. Lysozyme showed to enhance cell membrane permeability at a concentration of $0.3 \mathrm{mg} / \mathrm{mL}$. The MIC of metronidazole against $H$. pylori was reduced from 8 to $4 \mu \mathrm{g} / \mathrm{mL}$ and the mutant prevention concentration from $153.6 \mu \mathrm{g} / \mathrm{mL}$ to $25.6 \mu \mathrm{g} / \mathrm{mL}$.

The use of a combination between antimicrobial peptides, proteins, and conventional antibiotics was also the way to combat antibiotic resistance and proposed by a Russian team in 2019 [249]. The egg white lysozyme was studied in combination with glutamicin, ofloxacin, oxocillin, rifampicin, and polymyxin B against selected bacteria. The inhibitory concentrations indexes were evaluated using the checkerboard titrations method. The results are summarized in Tables 3 and 4 . 
Table 3. Antimicrobial activity of individual fractions of lysozyme and antibiotics against Gramnegative and Gram-positive bacteria.

\begin{tabular}{ccccc}
\hline & \multicolumn{3}{c}{ MIC $^{\text {a }}(\mu \mathrm{M})$ toward Bacterial Strains } \\
\cline { 2 - 5 } Sample & E. coli ML-35po & A. baumannii & MRSA ATCC & M. luteus CIP \\
& & & 33591 & 0.08 \\
\hline Lysozyme & $>250(500)$ & 1.2 & $>250(500)$ & 3.1 \\
Oxacillin & $>250(500)$ & 25 & 7.5 & 0.6 \\
Polymyxin B & 0.4 & 1.25 & 12.5 & 0.16 \\
Gentamicin & 0.625 & 0.06 & 0.16 & 0.003 \\
Rifampicin & 10 & 0.125 & 0.003 & 5 \\
Ofloxacin & 0.125 & 0.3 & 0.625 & \\
a MIC values are medians of 3-6 independent experiments made in triplicates. If the actual MIC value was out of \\
the tested concentrations range, it was assessed as twice the maximal tested concentration; the corresponding \\
value is given in square brackets.
\end{tabular}

Table 4. Antimicrobial activity of combinations of lysozyme with antibiotics against Gram-negative and Gram-positive bacteria.

\begin{tabular}{|c|c|c|c|c|c|c|c|c|c|c|c|}
\hline & \multicolumn{11}{|c|}{ Minimal FICIs ${ }^{\text {a }}$ of the Lysozyme $\backslash$ Antibiotic Combination (AB) against Bacteria } \\
\hline & \multicolumn{5}{|c|}{ Gram-Negative } & \multicolumn{6}{|c|}{ Gram-Positive } \\
\hline $\mathrm{AB}$ & RIF & PMB & GEN & OFL & OX & $\mathrm{AB}$ & RIF & PMB & GEN & OFL & OX \\
\hline \multicolumn{6}{|c|}{ E. coli ML-35p } & \multicolumn{6}{|c|}{ MRSA ATCC 33591} \\
\hline Lysozyme & 0.62 & 0.25 & 0.53 & 1.12 & - & Lysozyme & 0.62 & 0.56 & 0.53 & 1.12 & 0.53 \\
\hline \multicolumn{6}{|c|}{ A. baumannii } & \multicolumn{6}{|c|}{ M. luteus CIP A270 } \\
\hline Lysozyme & 1 & 0.5 & 0.75 & 1 & 1 & Lysozyme & 0.75 & 0.62 & 0.62 & 0.62 & 0.75 \\
\hline
\end{tabular}

A combination of linezolid, an antibiotic of oxazolidinones, and lysozyme was loaded and coated onto a metal organic framework (MOF) was suitably functionalized, and the antimicrobial property of the obtained system against Staphylococcus aureus, E. coli, and methicillin-resistant $S$. aureus was evaluated [250]. The chosen MOF was UiO-66- $\mathrm{NH}_{2}$, a metal organic compound made of $\left[\mathrm{Zr}_{6} \mathrm{O}_{4}(\mathrm{OH})_{4}\right]$ clusters with 1,4-benzodicarboxylic acid struts. By means of an amidation reaction, a photosensitizer (zinc phthalocyanine) was bound to the MOF and linezolid. Lysozyme was then loaded in the pores and on the surface of the MOF. The immobilized lysozyme could specifically react with the bacterial cell wall, allowing the nanomaterials to enter the bacteria more easily. The cytotoxic singlet oxygen, generated by the irradiation of the photosensitizer, in combination with immobilized linezolid and lysozyme, resulted in an in vitro potent antibacterial effect.

\section{L-Form Bacteria}

In this section, the synergy between conventional antibiotics and lysozyme was described. The combination of $\beta$-Lactams and immune enzymes, such as lysozyme, causes an unexpected effect, selecting for viable, wall-less bacteria. The peptidoglycans (PG) of the bacterial cell wall were synthesized and their dynamic structure maintained by the action of penicillin-binding proteins (PBPs) and autolysins, which build and hydrolyze PG, respectively. $\beta$-Lactams killed the bacteria since it bound and inactivated PBPs, preventing the PG synthesis. Lysozyme, on the contrary, cleaved the glycan structure and degrading PGs. Many bacteria, both Gram-positive and Gram-negative, can convert from rods into a spherical wall-deficient state, the "L-form", completely resistant to $\beta$-Lactams. The presence of L-forms was identified in humans, animals, and plants. 
The L-forms were discovered 80 years ago and, in 2018, Kawai et al. [251] published the results of their work aimed to explain the combined action of $\beta$-Lactams and lysozyme. Penicillin alone blocks L-form formation, inhibiting both synthesis, as previously reported in literature, and hydrolysis, which is essential, according to the authors, for inducing L-forms. The bacteria could exploit the host lysozyme to escape antibiotic-mediated killing by switching to an L-form. In a review published in the same year, Burke [252] collected in a scheme the various fates of bacteria upon $\beta$-Lactam treatment, depending on their environment and the presence or absence of lysozyme (Figure 5).

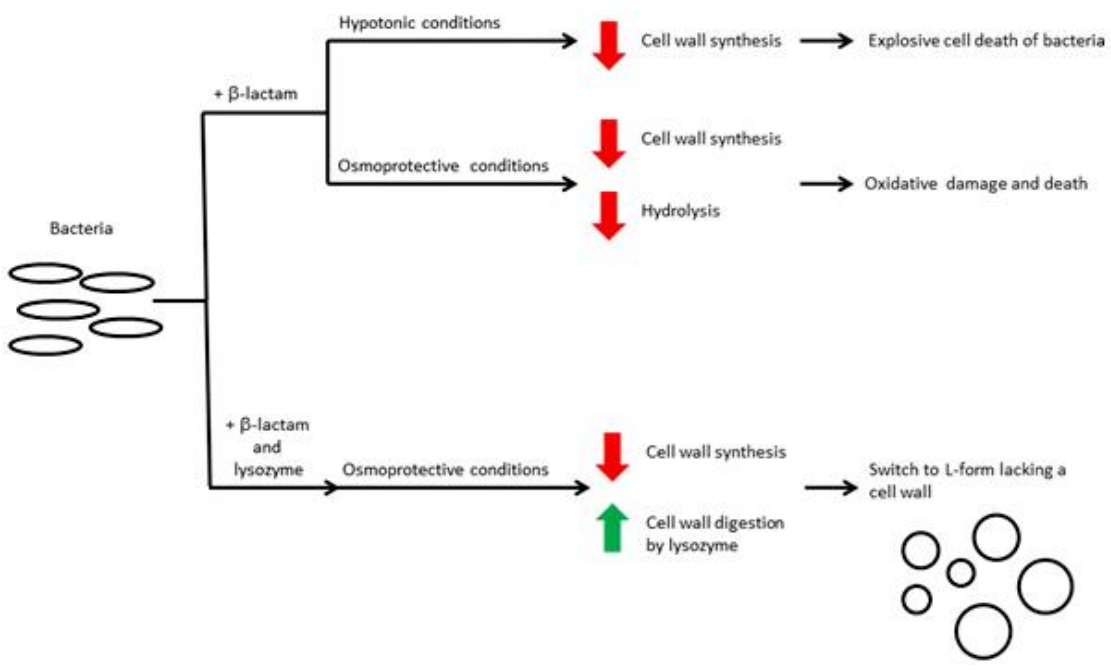

Figure 5. Various fates of bacteria upon $\beta$-Lactam treatment.

\subsection{Phages}

Vibriosis, caused by the Gram-negative bacteria of the genera Vibrio, is a common disease in marine and freshwater fish, both in natural and commercial production systems. Vibrio parahaemolyticus is an important human pathogenic bacterium. Its presence in the marine environments is frequently the cause of acute gastroenteritis in humans, after the consumption of raw or undercooked seafood. To avoid the administration of antibiotics in aquaculture, phage therapy is an interesting alternative and is well documented in literature. Phage genome injections into the host cell is facilitated by the lytic enzymes that digest the cell wall from the outside. Starting from these considerations, the effect of the external addition of a lytic enzyme, such as lysozyme from chicken egg whites to the phage, was studied [253]. Three phages (VP-1, VP-2, and VP-3) were isolated using $V$. parahaemolyticus as a host. The assays were performed with single-phage suspension and with a combination of the phage with lysozyme. The results showed that the addition of lysozyme to the samples had a positive effect on the phages' activity. The extent of the activity increase was dependent on the type of phage and on the lysozyme concentration. The three phages, in the presence of lysozyme $(10 \mathrm{mg} / \mathrm{mL})$, showed a higher efficiency to inactivate $V$. parahaemolyticus, in comparison to the results obtained with the phages alone. The lytic effect was not observed if lysozyme was used alone, but lysozyme improved the phage entrance in the host cells. VP-3 is the more effective phage and the addition of lysozyme showed only a small improvement, when compared with the other less active phages, VP-1 and VP-2. The bacterial inactivation of these two phages was seven and two times faster, respectively, in the presence of lysozyme, when compared with the results observed with the phages alone. The positive effect observed by adding lysozyme was explained with the increase in the number of phages produced by the bacteria. The same effect caused by the addition of $10 \mathrm{mg} / \mathrm{mL}$ of lysozyme to VP-1 and VP-2 was observed by the addition of $3 \mathrm{mg} / \mathrm{mL}$ to VP-3. 


\subsection{Selenium Nanoparticles}

Selenium is an essential trace element in the diet of living creatures at low concentrations, but it becomes toxic at higher concentrations. The least toxic form of selenium is elemental Se. Se nanoparticles are active against pathogenic bacteria, fungi, and yeast.

In a 2020 study [254], the interaction between selenium nanoparticles (SeNP) and lysozyme (from chicken egg whites) was investigated to verify if the nanohybrid (SeNP + Lys), with the nano and bio counterparts, can be endowed with a synergistic effect. The nanohybrid was analyzed using the dynamic light scattering technique to establish the sizes of the nanoparticles and circular dichroism spectropolarimetry to verify that lysozyme retained its native conformation, which is strictly related to the catalytic activity. The antibacterial efficiency of the individual components of the nanohybrid was tested against S. aureus and E. coli. The MIC of SeNPs against S. aureus was $82 \mu \mathrm{g} / \mathrm{mL}$. The MIC of lysozyme was $10 \mathrm{mg} / \mathrm{mL}$. Neither the nanoparticles nor the enzyme completely inhibited the growth of E. coli: the highest inhibition $(41 \%)$ was observed at $660 \mu \mathrm{g} / \mathrm{mL}$ of SeNPs and $2 \mathrm{mg} / \mathrm{mL}$ of lysozyme. The nanohybrid containing 50 and $100 \mu \mathrm{g} / \mathrm{mL}$ of lysozyme and the lowest amount of SeNPs induced the complete inhibition of S. aureus. Three low concentrations of SeNPs $(1,5,10 \mu \mathrm{g} / \mathrm{mL})$ with lysozyme were able to significantly increase the antibacterial activity against $S$. aureus, with respect to the protein alone. In the case of E. coli, the nanohybrid system with $330 \mu \mathrm{g} / \mathrm{mL}$ SeNPs and $2 \mathrm{mg} / \mathrm{mL}$ lysozyme presented the highest inhibition level (74\%). It was observed that both the nano and bio components acted synergistically in the nanohybrid.

\subsection{Plant Flavones}

Flavones are a class of plant secondary metabolites endowed with anti-inflammatory and antibacterial effects (Figure 6).<smiles>CC(=O)CC(c1ccccc1)c1c(O)c2ccccc2oc1=O</smiles><smiles>O=c1cc(-c2ccc(O)cc2)oc2cc(O)cc(O)c12</smiles><smiles>COc1c(O)cc(O)c2c(=O)cc(-c3ccccc3)oc12</smiles><smiles>O=c1cc(-c2ccccc2)oc2cc(O)cc(O)c12</smiles>

chrysin<smiles>COc1ccc(-c2cc(=O)c3c(O)c(OC)c(OC)c(OC)c3o2)cc1</smiles>

Figure 6. Chemical structure of some flavones.

The flavone apigenin, isolated in bee propolis and chamomile flowers, inhibits the enzyme D-ala-D-alanine ligase, which catalyzes the formation of the dipeptide D-ala-D-ala, the precursor of the peptidoglycan. Apigenin exerts a synergic action with $\beta$-Lactam against methicillin-resistant $S$. aureus. Similar antimicrobial effects have also been shown by other flavones, such as chrysin, warfarin, and tangeritin. The antimicrobial effect of flavones on three nasal pathogens frequently found in chronic rhinosinusitis patients, the yeast Candida albicans, the Gram-positive Staphylococcus aureus, and Gram-negative Pseudomonas aeruginosa was investigated in 2017 [255]. The very subtle effects observed in the case of $C$. albicans and $S$. aureus were in contrast with the more marked effect in $P$. 
aeruginosa. A flavones mixture significantly reduced planktonic growth and the culture optical density at $600 \mathrm{~nm}\left(\mathrm{OD}_{600}\right)$, a measure of bacteria lysis. The effect of flavones on the efficacy of airway antimicrobials, such as lysozyme, against $P$. aeruginosa was also tested in the same study. The rapid lysis of P. aeruginosa (decrease in OD ${ }_{600}$ ) was detected in the presence of rhLys and flavones. A mixture of flavones (100 $\mu \mathrm{M}$ each) significantly enhanced lysozyme-mediated P. aeruginosa lysis, while individual flavones did not enhance lysozyme-mediated lysis.

\subsection{Galleria Mellonella Apolipophorin III}

Apolipophorin III is a hemolymph protein functioning in the lipid transport and immune response in insects. It is active against Gram-positive and Gram-negative bacteria. In a 2013 article [256], the synergistic action of Apolipophorin III from Galleria mellonella with lysozyme was investigated. The authors demonstrated that the permeabilizing activity of lysozyme toward E. coli cells increased significantly in the presence of Apolipophorin III, which was devoid of the ability to perforate the bacteria when used alone.

\section{Lysozyme Modifications}

The wide application field of lysozyme, with its antibacterial specificity against certain Gram-positive bacteria and, to a less extent, against Gram-negative bacteria, prompted the study of lysozyme modifications. The research of modified lysozyme forms is finalized to achieve more active or more stable lysozyme derivatives. The modifications can affect the chemical structure of the protein or its physical properties, mainly electric charges.

\subsection{Immobilization}

Immobilization is a traditional method aimed at obtaining more stable and easier to handle enzymes [257]. The immobilization techniques used to or within support can be classified as physical (weak interactions between the support and the enzyme) or chemical (covalent bonds formation between the support and the enzyme). The physical methods include the adsorption on the surface (hydrophobic, electrostatic interactions, and hydrogens bonds) and the entrapment in a structure chemically inert toward the protein. The chemical methods can exploit functional groups of the protein to form covalent bonds with the support, or bifunctional reagents, such as glutaraldehyde, which act as a link between the enzyme and the support. The use of bifunctional reagents can also lead to the formation of the so-called cross-linked enzyme aggregates (CLEAs) [258].

The obtained lysozyme derivatives showed a decreased antibiotic activity against $M$. luteus in respect to the native lysozyme, but, at times, the modified lysozyme also became active against some Gram-negative microorganisms.

In Table 5, several immobilized lysozyme preparations active against several reported microorganisms are collected. For each example, the immobilization technique and the possible applications are briefly described.

Table 5. Immobilization of lysozyme.

\begin{tabular}{ccccc}
\hline Support & $\begin{array}{c}\text { Tested } \\
\text { Microorganisms }\end{array}$ & $\begin{array}{c}\text { Reagent or Immobilization } \\
\text { Technique }\end{array}$ & Applications/Claimed Uses & Refs. \\
\hline Vitreous surface & E. coli & Water decontamination & $\begin{array}{c}\text { Antibacterial } \\
\text { [259] }\end{array}$ \\
\hline Wool fabric & S. aureus & Glutaraldehyde & $\begin{array}{c}\text { functionalization for textile } \\
\text { goods }\end{array}$ & $\begin{array}{c}\text { Antibacterial } \\
\text { [260] }\end{array}$ \\
Wool fabric & E. coli & Tris(hydroxymethyl)phosphine & $\begin{array}{c}\text { functionalization for textile } \\
\text { goods }\end{array}$ \\
\hline Cotton fabric & M. lysodeikticus & Glycine esterified & Medical hygiene \\
\hline
\end{tabular}


Table 5. Cont

\begin{tabular}{|c|c|c|c|c|}
\hline Support & $\begin{array}{c}\text { Tested } \\
\text { Microorganisms }\end{array}$ & $\begin{array}{c}\text { Reagent or Immobilization } \\
\text { Technique }\end{array}$ & Applications/Claimed Uses & Refs. \\
\hline Silk textiles & $\begin{array}{l}\text { S. aureus } \\
\text { E. coli }\end{array}$ & Physically adsorbed & Functional wound dressing & {$[263]$} \\
\hline $\begin{array}{l}\text { Polyacrylonitrile } \\
\text { membranes }\end{array}$ & S. aureus & Glutaraldehyde & $\begin{array}{l}\text { Water treatment } \\
\text { and food manufacturing }\end{array}$ & {$[264]$} \\
\hline $\begin{array}{c}\text { Polyacrylonitrile } \\
\text { membrane hydrolyzed }\end{array}$ & $\begin{array}{l}\text { E. coli } \\
\text { S. aureus }\end{array}$ & Layer-by-layer self-assembly & $\begin{array}{l}\text { Antibacterial thin film } \\
\text { composite } \\
\text { membranes for aqueous } \\
\text { molecular separation }\end{array}$ & {$[265]$} \\
\hline $\begin{array}{l}\text { Polystyrene/poly } \\
\text { (styrene-10-maleic } \\
\text { anhydride) }\end{array}$ & S. aureus & CLEA & $\begin{array}{c}\text { Antimicrobial process in } \\
\text { biomedical and engineering } \\
\text { industries }\end{array}$ & {$[266]$} \\
\hline Polyethylene glycol & $\begin{array}{l}\text { L. ivanovii } \\
\text { M. luteus }\end{array}$ & $\begin{array}{l}\text { Reductive amination on } \\
\text { pretreated stainless steel } \\
\text { surface }\end{array}$ & Antifouling agents & {$[125]$} \\
\hline $\begin{array}{c}\text { Poly(3,4- } \\
\text { ethylenedioxythiophene) } \\
\text { (PEDOT) }\end{array}$ & S. epidermidis & Incorporations in films & Regeneration of tissues & {$[267]$} \\
\hline Cellulose acetate & S. aureus & $\begin{array}{l}\text { Electrostatic adsorption, } \\
\text { electrospraying }\end{array}$ & $\begin{array}{l}\text { Food packaging and } \\
\text { antimicrobial wound } \\
\text { dressing }\end{array}$ & {$[268]$} \\
\hline $\begin{array}{l}\text { Gelatin/sodium car- } \\
\text { boxymethylcellulose }\end{array}$ & $\begin{array}{l}\text { S. aureus } \\
\text { P. aeruginosa } \\
\text { E. coli }\end{array}$ & $\begin{array}{l}\text { Inclusion in a polymeric } \\
\text { matrix }\end{array}$ & $\begin{array}{l}\text { Mucoadhesive form of } \\
\text { lysozyme }\end{array}$ & {$[269]$} \\
\hline Alginate, iron cations & M. luteus & Entrapment & Food packaging materials & {$[270]$} \\
\hline Chitosan & $\begin{array}{l}\text { S. aureus } \\
\text { B. subtilis } \\
\text { S. flexneri } \\
\text { P. aeruginosa }\end{array}$ & CLEA & $\begin{array}{l}\text { Repeated uses as } \\
\text { antimicrobial material }\end{array}$ & {$[271]$} \\
\hline Chitosan/alginate & $\begin{array}{l}\text { E. coli } \\
\text { S. aureus }\end{array}$ & Hydrogel & Food industry & {$[272]$} \\
\hline $\begin{array}{l}\text { Calcium phosphate on } \\
\text { chitosan }\end{array}$ & M. lysodeikticus & Incorporation & Bone tissue engineering & {$[273]$} \\
\hline Xanthan & M. luteus & Hydrogel & Wound dressing & {$[274]$} \\
\hline $\begin{array}{c}\text { Agarose, free amino } \\
\text { acids }\end{array}$ & $\begin{array}{l}\text { Gram-positive } \\
\text { Gram-negative }\end{array}$ & Reductive amination & $\begin{array}{l}\text { Blood plasma and whole } \\
\text { blood purification by } \\
\text { extracorporeal therapy } \\
\text { procedures }\end{array}$ & {$[275]$} \\
\hline Agarose, sericin & $\begin{array}{l}\text { E. coli } \\
\text { S. aureus }\end{array}$ & Gel & Wound dressing & {$[276]$} \\
\hline $\begin{array}{l}\text { Polysaccharides } \\
\text { particles or liposome }\end{array}$ & $\begin{array}{c}\text { B. subtilis } \\
\text { M. luteus } \\
\text { E. coli } \\
\text { S. marcescens }\end{array}$ & $\begin{array}{c}\text { Encapsulation with herbal } \\
\text { extracts }\end{array}$ & $\begin{array}{l}\text { Food preservation and } \\
\text { wound healing }\end{array}$ & {$[277]$} \\
\hline Exopolysaccharides & E. coli & Incorporation into films & $\begin{array}{l}\text { Biodegradable coatings for } \\
\text { fruits and vegetables }\end{array}$ & {$[278]$} \\
\hline Graphene oxide & E. coli & Electrostatic interactions & Antibacterial membranes & {$[279]$} \\
\hline $\begin{array}{l}\text { Graphene oxide, } \\
\text { polydopamine }\end{array}$ & E. coli & $\begin{array}{l}\text { Electrostatic and hydrogen } \\
\text { bond interactions }\end{array}$ & $\begin{array}{l}\text { Medical treatments and food } \\
\text { safety fields }\end{array}$ & {$[280]$} \\
\hline Capsid & M. luteus & Encapsulation & $\begin{array}{l}\text { Nanoreactor at physiological } \\
\text { conditions }\end{array}$ & {$[281]$} \\
\hline
\end{tabular}


Table 5. Cont.

\begin{tabular}{|c|c|c|c|c|}
\hline Support & $\begin{array}{c}\text { Tested } \\
\text { Microorganisms }\end{array}$ & $\begin{array}{c}\text { Reagent or Immobilization } \\
\text { Technique }\end{array}$ & Applications/Claimed Uses & Refs. \\
\hline Balsa & $\begin{array}{l}\text { E. coli } \\
\text { S. aureus }\end{array}$ & Encapsulation & Wound healing & {$[282,283]$} \\
\hline Calcium carbonate & M. lysodeikticus & Encapsulation & $\begin{array}{l}\text { Catalysis, disease treatment, } \\
\text { and tissue engineering }\end{array}$ & [284] \\
\hline $\begin{array}{l}\text { Layered double } \\
\text { hydroxide }\end{array}$ & $\begin{array}{l}\text { E. coli } \\
\text { S. aureus }\end{array}$ & Van der Waals forces & Wound healing & [285] \\
\hline Silica & $\begin{array}{l}\text { E. coli } \\
\text { S. aureus }\end{array}$ & Entrapment & $\begin{array}{l}\text { Coating containers used to } \\
\text { store chirurgical devices, } \\
\text { catheters, implants, } \\
\text { artificial prosthetics, and } \\
\text { other materials to reduce } \\
\text { hospital } \\
\text { infections }\end{array}$ & [286] \\
\hline Laser sintered titanium & $\begin{array}{l}\text { S. gordonii } \\
\text { S. sanguis }\end{array}$ & Layer-by-layer self-assembly & Biofilm inhibition & [132] \\
\hline Niclosamide & $\begin{array}{c}\text { MRSA } \\
\text { MERS-COV } \\
\text { SARS-CoV-2 }\end{array}$ & $\begin{array}{l}\text { Embedded in h-Lys for } \\
\text { inhalation route }\end{array}$ & $\begin{array}{l}\text { Delivery to the upper and } \\
\text { lower respiratory tracts }\end{array}$ & [287] \\
\hline Lactic acid & $\begin{array}{c}\text { B. cereus } \\
\text { E. coli } \\
\text { S. typhimurium }\end{array}$ & Gelled egg white powder & Food industry & [288] \\
\hline $\begin{array}{c}\text { Microbubbles, } \\
\text { immobilized gold NPs }\end{array}$ & M. lysodeikticus & Pressurized gyration & $\begin{array}{l}\text { Biosensor for the detection of } \\
\text { analytes in aqueous solutions }\end{array}$ & [289] \\
\hline $\begin{array}{l}\text { Microbubbles, } \\
\text { immobilized gold NPs, } \\
\text { and polyvinyl alcohol }\end{array}$ & E. coli & Pressurized gyration & $\begin{array}{l}\text { Diagnostic tools and } \\
\text { environmental bioassays }\end{array}$ & [290] \\
\hline
\end{tabular}

Lysozyme was also immobilized on various nanostructured materials by adsorption or covalent attachment [291]; in Table 6, several already developed applications or future promising uses are reported.

Table 6. Lysozyme modifications and nanotechnologies.

\begin{tabular}{|c|c|c|c|c|}
\hline \multicolumn{5}{|c|}{ NANOMATERIAL } \\
\hline & $\begin{array}{c}\text { Tested } \\
\text { Microorganisms }\end{array}$ & Reagent or Method & $\begin{array}{c}\text { Applications/Claimed } \\
\text { Uses }\end{array}$ & Refs. \\
\hline Cellulose nanocrystals & $\begin{array}{c}\text { M. lysodeikticus } \\
\text { Corynebacterium sp. } \\
\text { E. coli } \\
\text { P. mendocina }\end{array}$ & Glutaraldehyde & $\begin{array}{l}\text { Improved antibacterial } \\
\text { action also against } \\
\text { Gram-negative bacteria }\end{array}$ & [292] \\
\hline Cellulose nanocrystals & B. subtilis & Cellulose-CHO & Inhibition of biofilm & [110] \\
\hline $\begin{array}{c}\text { Cellulose acetate } \\
\text { nanofibers, sodium } \\
\text { alginate }\end{array}$ & S. aureus & $\begin{array}{l}\text { Electrostatic } \\
\text { interactions }\end{array}$ & $\begin{array}{l}\text { Milk and dairy } \\
\text { products }\end{array}$ & [293] \\
\hline $\begin{array}{l}\text { Cellulose acetate } \\
\text { nanofibrous LBL }\end{array}$ & $\begin{array}{l}\text { E. coli } \\
\text { S. aureus }\end{array}$ & $\begin{array}{l}\text { Electrostatic } \\
\text { interactions }\end{array}$ & $\begin{array}{l}\text { Food packaging, } \\
\text { adhesive wound } \\
\text { dressing, and tissue } \\
\text { engineering }\end{array}$ & [294] \\
\hline $\begin{array}{c}\text { Cellulose } \\
\text { NPs/b-chitosan }\end{array}$ & $\begin{array}{l}\text { L. innocua } \\
\text { E. coli }\end{array}$ & Encapsulation & $\begin{array}{l}\text { Packaging material for } \\
\text { shelf life extension }\end{array}$ & [295] \\
\hline
\end{tabular}


Table 6. Cont

\begin{tabular}{|c|c|c|c|c|}
\hline \multicolumn{5}{|c|}{ NANOMATERIAL } \\
\hline & $\begin{array}{c}\text { Tested } \\
\text { Microorganisms }\end{array}$ & Reagent or Method & $\begin{array}{c}\text { Applications/Claimed } \\
\text { Uses }\end{array}$ & Refs. \\
\hline Nanocellulose aerogel & $\begin{array}{l}\text { S. aureus } \\
\text { E. coli }\end{array}$ & $\begin{array}{l}\text { Electrostatic } \\
\text { interactions }\end{array}$ & Wound dressings & [296] \\
\hline Chitin nanowhiskers & $\begin{array}{l}\text { E. coli } \\
\text { S. aureus } \\
\text { B. subtilis }\end{array}$ & Adsorption & $\begin{array}{l}\text { Enhancement of the } \\
\text { antibacterial efficiency } \\
\text { for food preservation }\end{array}$ & [297] \\
\hline Chitosan NPs/tannin & $\begin{array}{c}\text { S. aureus } \\
\text { S. enteriditis } \\
\text { L. monocytogenes }\end{array}$ & Encapsulation & Food industry & [298] \\
\hline Chitosan NPs & S. epidermidis & & $\begin{array}{c}\text { Encapsulation of } \\
\text { antimicrobial peptides }\end{array}$ & [299] \\
\hline $\begin{array}{l}\text { Poly- } \gamma \text {-glutamic acid, } \\
\text { chitosan NPs }\end{array}$ & $\begin{array}{l}\text { E. coli } \\
\text { B. subtilis }\end{array}$ & Loading & $\begin{array}{c}\text { Controlled } \\
\text { delivery system }\end{array}$ & [300] \\
\hline $\begin{array}{l}\text { Polystyrene } \\
\text { nanospheres }\end{array}$ & E. coli & Electrospinning & $\begin{array}{l}\text { Food processing and } \\
\text { medical equipment }\end{array}$ & [301] \\
\hline $\begin{array}{l}\text { Nanopatterned } \\
\text { poly(isopropylacrylamide) }\end{array}$ & $\begin{array}{l}\text { E. coli } \\
\text { S. epidermidis }\end{array}$ & Adsorption & $\begin{array}{l}\text { Mitigation of } \\
\text { short-term bacterial } \\
\text { biofouling }\end{array}$ & [302] \\
\hline Eugenol-casein NPs & $\begin{array}{l}\text { S. aureus } \\
\text { Bacillus sp. }\end{array}$ & Encapsulation & Food preservation & [303] \\
\hline $\begin{array}{l}\text { Melanosome } \\
\text { nanostructures }\end{array}$ & MRSA & $\begin{array}{l}\text { Electrostatic } \\
\text { interactions }\end{array}$ & Tissue repair & [304] \\
\hline Glass NPs & $\begin{array}{l}\text { B. subtilis, (human } \\
\text { hepatocellular } \\
\text { carcinoma) }\end{array}$ & $\begin{array}{l}\text { Electrostatic } \\
\text { interactions }\end{array}$ & $\begin{array}{l}\text { Treatment of bone } \\
\text { defects caused by } \\
\text { tumors }\end{array}$ & [305] \\
\hline $\begin{array}{c}\text { Carbon NTs } \\
\text { single-wallet carbon } \\
\text { nanotubes }\end{array}$ & M. lysodeikticus & $\begin{array}{l}\text { Noncovalent or } \\
\text { covalent interactions }\end{array}$ & $\begin{array}{c}\text { Covalent } \\
\text { functionalization led to } \\
\text { improved dispersion } \\
\text { stability and longer } \\
\text { duration of bacterial } \\
\text { lysis relative to } \\
\text { noncovalent lysozyme } \\
\text { single-walled carbon } \\
\text { nanotubes }\end{array}$ & {$[306,307]$} \\
\hline $\begin{array}{l}\text { Single walled carbon } \\
\text { NTs, DNA fibers }\end{array}$ & M. lysodeikticus & $\begin{array}{l}\text { Spinning, electrostatic } \\
\text { interactions }\end{array}$ & $\begin{array}{l}\text { Drug delivery, tissue } \\
\text { engineering, and } \\
\text { biocompatible } \\
\text { composites }\end{array}$ & [308] \\
\hline Nanodiamonds & E. coli & $\begin{array}{l}\text { Electrostatic } \\
\text { interactions }\end{array}$ & $\begin{array}{l}\text { Biolabel to observe the } \\
\text { interaction of Lys with } \\
\text { bacteria }\end{array}$ & [309] \\
\hline Silica NPs & E. coli & $\begin{array}{l}\text { Electrostatic } \\
\text { interactions }\end{array}$ & $\begin{array}{c}\text { Highly efficient } \\
\text { antibacterial agent } \\
\text { in vitro and in vivo } \\
\text { with low cytotoxicity } \\
\text { and negligible } \\
\text { hemolytic activity }\end{array}$ & [310] \\
\hline $\begin{array}{l}\text { Silicon nanowires, poly } \\
\text { (methacrylic acid) }\end{array}$ & E. coli & Adsorption & $\begin{array}{c}\text { Engineering of surfaces } \\
\text { with switchable } \\
\text { functionalities }\end{array}$ & [311] \\
\hline
\end{tabular}


Table 6. Cont

\begin{tabular}{|c|c|c|c|c|}
\hline \multicolumn{5}{|c|}{ NANOMATERIAL } \\
\hline & $\begin{array}{c}\text { Tested } \\
\text { Microorganisms }\end{array}$ & Reagent or Method & $\begin{array}{c}\text { Applications/Claimed } \\
\text { Uses }\end{array}$ & Refs. \\
\hline Halloysite NTs & E. coli & $\begin{array}{c}\text { 1,6-hexan-ethylene } \\
\text { diisocyanate }\end{array}$ & $\begin{array}{l}\text { Reduced fouling in } \\
\text { water treatment }\end{array}$ & [312] \\
\hline $\begin{array}{l}\text { Montmorillonite } \\
\text { K10-silver NPs }\end{array}$ & $\begin{array}{c}\text { E. coli } \\
\text { P. aeruginosa } \\
\text { MRSA } \\
\text { L. monocytogenes }\end{array}$ & Complexes & $\begin{array}{l}\text { Activity against } \\
\text { antibiotic resistant } \\
\text { bacterial strains }\end{array}$ & [313] \\
\hline $\begin{array}{l}\text { Montmorillonite-silver } \\
\text { NPs }\end{array}$ & $\begin{array}{l}\text { E. coli } \\
\text { S. aureus }\end{array}$ & Complexes & $\begin{array}{c}\text { Production of sorbents } \\
\text { with antibiotic } \\
\text { properties }\end{array}$ & [314] \\
\hline $\begin{array}{l}\text { Rectorite nanofibrous } \\
\text { membrane }\end{array}$ & $\begin{array}{l}\text { S. aureus } \\
\text { E. coli }\end{array}$ & Electrospinning & $\begin{array}{l}\text { Food engineering and } \\
\text { biomedical materials }\end{array}$ & [315] \\
\hline $\begin{array}{l}\text { Molybdenum disulfide } \\
\text { nanosheets }\end{array}$ & $\begin{array}{c}\text { Ampicillin-resistant } E \text {. } \\
\text { coli } \\
\text { B. subtilis }\end{array}$ & $\begin{array}{l}\text { Electrostatic } \\
\text { interactions }\end{array}$ & $\begin{array}{c}\text { Design and synthesis of } \\
\text { novel nanozyme } \\
\text { antibacterial agents }\end{array}$ & [316] \\
\hline $\begin{array}{l}\text { Molybdenum disulfide } \\
\text { nanosheets }\end{array}$ & $\begin{array}{l}\text { E. coli } \\
\text { S. aureus }\end{array}$ & Coating & $\begin{array}{c}\text { Microfiltration } \\
\text { membrane for water } \\
\text { purification }\end{array}$ & [317] \\
\hline Zinc oxide NPs & $\begin{array}{l}\text { E. coli } \\
\text { S. aureus }\end{array}$ & $\begin{array}{c}\text { Glutaraldehyde + } \\
\text { aminated ZnO NPs }\end{array}$ & Biomedical & [318] \\
\hline Titania nanosheets & M. lysodeikticus & $\begin{array}{c}\text { Layer-by-layer } \\
\text { technique, electrostatic } \\
\text { interactions }\end{array}$ & Antibacterial coatings & [319] \\
\hline $\begin{array}{l}\text { Layered double } \\
\text { hydroxide } \\
\text { nanocomposites }\end{array}$ & $\begin{array}{l}\text { E. coli } \\
\text { B. subtilis }\end{array}$ & Loading & $\begin{array}{l}\text { Water purification } \\
\text { processes }\end{array}$ & [320] \\
\hline $\begin{array}{c}\text { Gold capped } \\
\text { nanoclusters with } \\
\text { ampicillin }\end{array}$ & MRSA & & Wound healing & [321] \\
\hline Gold NPs & \multirow[t]{2}{*}{ B. subtilis } & $\begin{array}{c}\text { Tryptophan residues of } \\
\text { Lys }+ \text { N-bromo } \\
\text { succinimide }\end{array}$ & \multirow{2}{*}{$\begin{array}{l}\text { Drug delivery and } \\
\text { bioimaging }\end{array}$} & \multirow{2}{*}{ [322] } \\
\hline Silver NPs & & $\begin{array}{c}\text { Tyrosine residues of } \\
\text { Lys + N-acetyl } \\
\text { imidazole }\end{array}$ & & \\
\hline Gold NPs & $\begin{array}{l}\text { S. epidermidis } \\
\text { E. coli }\end{array}$ & Layer by layer & $\begin{array}{l}\text { Long-term antibacterial } \\
\text { coating, biocatalysis, } \\
\text { and biosensor }\end{array}$ & [323] \\
\hline Gold NPs & $\begin{array}{c}\text { Acinetobacter baumanii } \\
\text { Enterococcus faecalis }\end{array}$ & & $\begin{array}{l}\text { Bacterial labeling and } \\
\text { antimicrobial agents } \\
\text { against antibiotic } \\
\text { resistant bacteria }\end{array}$ & [324] \\
\hline Gold NPs & $\begin{array}{l}\text { S. aureus } \\
\text { E. coli }\end{array}$ & Hybrid film & $\begin{array}{l}\text { Killing and removal of } \\
\text { adherent bacteria on } \\
\text { the surfaces of medical } \\
\text { devices }\end{array}$ & [325] \\
\hline Silver NPs & $\begin{array}{c}\text { E. coli } \\
\text { S. aureus } \\
\text { B. anthracis } \\
\text { C. albicans } \\
\text { resistant } P \text {. mirabilis }\end{array}$ & $\begin{array}{l}\text { Nanoparticles from } \\
\text { stable colloid (silver } \\
\text { acetate and lys in } \\
\text { methanol) }\end{array}$ & $\begin{array}{l}\text { Aseptic and } \\
\text { therapeutic use }\end{array}$ & [326] \\
\hline
\end{tabular}


Table 6. Cont

\begin{tabular}{ccccc}
\hline & NANOMATERIAL & & \\
\hline & $\begin{array}{c}\text { Tested } \\
\text { Microorganisms }\end{array}$ & Reagent or Method & $\begin{array}{c}\text { Applications/Claimed } \\
\text { Uses }\end{array}$ & Refs. \\
\hline $\begin{array}{c}\text { Silver NPs in nanogel } \\
\text { (dextran + lys) }\end{array}$ & $\begin{array}{c}\text { E. coli } \\
\text { S. aureus }\end{array}$ & $\begin{array}{c}\text { Maillard reaction } \\
\text { (nanogel), AgNPs } \\
\text { embedded in nanogel }\end{array}$ & $\begin{array}{c}\text { Inhibition of biofilm } \\
\text { formation }\end{array}$ \\
\hline
\end{tabular}

\subsection{Chemical Modifications}

The peptide chain of lysozyme can be modified by a proteolytic transformation aimed to isolate fragments still enzymatically active or showing a different activity, probably due to the electric charges present on the protein surface, against Gram-negative bacteria and/or other microorganisms [328,329]. An opposite approach provides the elongation of the chain by the fusion with different material or sulfidic proteins or peptides. Moreover, conjugates or complexes of lysozyme derivatives can be obtained by a reaction with polysaccharides and fatty acids with the aim to modify the hydrophobicity or the electric charges of the protein. Finally, the modifications of functional groups present in the side chain of some amino acid residues by oxidation or reduction are reported in literature.

Several examples of chemical modifications, improving the lysozyme activity, and the related potential applications are reported in Table 7.

Table 7. Chemical modifications of lysozyme.

\begin{tabular}{|c|c|c|c|c|}
\hline \multicolumn{5}{|c|}{ FRAGMENTATION } \\
\hline & Microorganisms & Method & Applications/Claimed Uses & Refs. \\
\hline Nine amino acids & Viral infection & Clostripain & $\begin{array}{l}\text { HIV infection and inhibition of } \\
\text { tumor growth }\end{array}$ & [330] \\
\hline $\begin{array}{l}\text { Bactericidal domain from } \\
\text { human milk Lys }\end{array}$ & $\begin{array}{l}\text { E. coli } \\
\text { S. aureus } \\
\text { C. albicans }\end{array}$ & Pepsin, pH 4 & Treatment of microbial infections & {$[20]$} \\
\hline From c-type Lys & $\begin{array}{l}\text { Gram-positive } \\
\text { Gram-negative }\end{array}$ & Pepsin, pH 4 & Treatment of microbial infections & [331] \\
\hline From goose egg white Lys & $\begin{array}{c}\text { E. coli } \\
\text { B. bronchiseptica } \\
\text { S. enteridis } \\
\text { H. pylori } \\
\text { S. aureus } \\
\text { S. epidermidis } \\
\text { B. subtilis } \\
\text { M. luteus }\end{array}$ & Pepsin, $\mathrm{pH} 2$ & Treatment of microbial infections & [16] \\
\hline From hen egg white Lys & $\begin{array}{l}\text { E. coli } \\
\text { S. carnosus }\end{array}$ & Pepsin, pH 2 & Treatment of microbial infections & [332] \\
\hline $\begin{array}{l}\text { Pentadecapeptide from } \\
\text { chicken egg white Lys }\end{array}$ & E. coli & Clostripain & $\begin{array}{c}\text { Treatment of microbial infections } \\
\text { and nontoxic against } \\
\text { erythrocytes }\end{array}$ & [333] \\
\hline \multicolumn{5}{|c|}{ FUSION PEPTIDES and PROTEINS } \\
\hline Fusion Product & Microorganisms & & Applications/Claimed Uses & Refs. \\
\hline Human $\beta$-defensin-3-lysozyme & $\begin{array}{l}\text { MRSA } \\
\text { S. aureus }\end{array}$ & & Therapy of MRSA infection & [334] \\
\hline $\begin{array}{l}\text { Pesticin-N-terminus of T4 } \\
\text { lysozyme }\end{array}$ & $\begin{array}{l}\text { E. coli } \\
\text { Yersinia }\end{array}$ & & $\begin{array}{l}\text { Therapeutic application to a } \\
\text { wide variety of Yersiniae and } \\
\text { pathogenic E. coli strains }\end{array}$ & [335] \\
\hline
\end{tabular}


Table 7. Cont.

\begin{tabular}{|c|c|c|c|c|}
\hline \multicolumn{5}{|c|}{ FRAGMENTATION } \\
\hline & Microorganisms & Method & Applications/Claimed Uses & Refs. \\
\hline $\begin{array}{l}\text { Propeptide of surfactant } \\
\text { protein B }\end{array}$ & $\begin{array}{l}\text { Streptococci } \\
\text { P. aeruginosa }\end{array}$ & & $\begin{array}{l}\text { Prophylaxis or therapeutic } \\
\text { treatment of respiratory and } \\
\text { gastrointestinal bacterial } \\
\text { infection }\end{array}$ & [152] \\
\hline Chimeric polypeptides & $\begin{array}{l}\text { P. aeruginosa, } \\
\text { K. pneumoniae } \\
\text { E. coli } \\
\text { A. baumanii } \\
\text { S. typhimurium } \\
\text { S. infantis } \\
\text { Shigella } \\
\text { P. mirabilis } \\
\text { B. thailandensis }\end{array}$ & & $\begin{array}{c}\text { Preparation of new enzymes } \\
\text { active against Gram-negative } \\
\text { bacteria }\end{array}$ & [336] \\
\hline Chimeric phage lysin & S. pneumoniae & & $\begin{array}{l}\text { Treatment of multiresistant } \\
\text { pneumococcal infections }\end{array}$ & [128] \\
\hline $\begin{array}{l}\text { N-terminal hexapeptide-Sus } \\
\text { scrofa lysozyme }\end{array}$ & $\begin{array}{l}\text { B. licheniformis } \\
\text { B. subtilis } \\
\text { M. lysodeikticus } \\
\text { S. aureus } \\
\text { E. coli } \\
\text { K. pneumoniae } \\
\text { P. aeruginosa } \\
\text { S. enteritidis }\end{array}$ & & $\begin{array}{l}\text { Antibacterial lysozyme } \\
\text { derivatives as components of } \\
\text { food additives. }\end{array}$ & [337] \\
\hline \multicolumn{5}{|c|}{ CONJUGATES and COMPLEXES } \\
\hline Starting Material & Microorganism & $\begin{array}{l}\text { Method or } \\
\text { Reagent }\end{array}$ & Applications/Claimed Uses & Refs. \\
\hline Chitosan & $\begin{array}{l}\text { P.aeruginosa } \\
\text { A. baumannii } \\
\text { MRSA }\end{array}$ & Maillard reaction & Control of refractory infections & [338] \\
\hline Chitosan film & $\begin{array}{l}\text { S. faecalis } \\
\text { E. coli }\end{array}$ & & $\begin{array}{l}\text { Surface coating on perishable } \\
\text { fruits and vegetables to enhance } \\
\text { microbial safety and extend shelf } \\
\text { life of the products }\end{array}$ & [171] \\
\hline Chitosan-silicon & E. coli & & $\begin{array}{c}\text { New recyclable antibacterial } \\
\text { materials }\end{array}$ & [339] \\
\hline Chitosan hydrogel & $\begin{array}{l}\text { S. aureus } \\
\text { E. coli }\end{array}$ & Methacrylate & $\begin{array}{c}\text { Tissue engineering and wound } \\
\text { healing }\end{array}$ & [340] \\
\hline Chitosan, alginate complexes & E. coli & & $\begin{array}{l}\text { Medical preparations } \\
\text { characterized by a sustained } \\
\text { release and resistance to } \\
\text { aggressive environmental } \\
\text { conditions }\end{array}$ & [341] \\
\hline Dextran sulfate & $\begin{array}{l}\text { S. aureus } \\
\text { E. coli }\end{array}$ & Maillard reaction & $\begin{array}{l}\text { Ingredient in formulated food } \\
\text { systems or as therapeutic agent }\end{array}$ & [342] \\
\hline Xanthan & $\begin{array}{l}\text { M. lysodeikticus } \\
\text { S. aureus } \\
\text { E. coli }\end{array}$ & Maillard reaction & $\begin{array}{l}\text { Functional ingredient with high } \\
\text { quality emulsifier, foam } \\
\text { producer, or natural antibacterial } \\
\text { agent in food }\end{array}$ & [343] \\
\hline Ulvan & S. aureus & $\begin{array}{l}\text { Polyelectrolyte } \\
\text { complexes }\end{array}$ & $\begin{array}{c}\text { Nanocarrier for positively } \\
\text { charged bioactive molecules }\end{array}$ & [344] \\
\hline
\end{tabular}


Table 7. Cont.

\begin{tabular}{|c|c|c|c|c|}
\hline \multicolumn{5}{|c|}{ FRAGMENTATION } \\
\hline & Microorganisms & Method & Applications/Claimed Uses & Refs. \\
\hline Oleyl chloride & E. coli & $\begin{array}{l}\text { Covalent bond } \\
\text { (amide) }\end{array}$ & Increase in hydrophobicity & {$[345]$} \\
\hline Oleic acid & S. pneumoniae & Complex & $\begin{array}{l}\text { Bactericidal activity against } \\
\text { bacterial species with a } \\
\text { respiratory tropism }\end{array}$ & {$[346]$} \\
\hline Transferrin (human) & Gram-positive & $\begin{array}{l}\text { Homofunctional } \\
\text { linker }\end{array}$ & $\begin{array}{l}\text { Delivery of the composition in } \\
\text { the CNS by crossing the } \\
\text { blood-brain-barrier }\end{array}$ & {$[347]$} \\
\hline $\begin{array}{l}\text { Monomethoxy polyethylene } \\
\text { glycol }\end{array}$ & $\begin{array}{c}\text { E. coli } \\
\text { P. aeruginosa }\end{array}$ & $\begin{array}{l}\text { Succinyl ester of } \\
\text { mPEG }\end{array}$ & Increase in hydrophobicity & {$[348]$} \\
\hline $\begin{array}{l}\text { Monomethoxy polyethylene } \\
\text { glycol }\end{array}$ & M. luteus & $\begin{array}{l}\text { Tetrafluorophenyl } \\
\text { 4-(mPEG)-4- } \\
\text { oxobutanoate }\end{array}$ & $\begin{array}{l}\text { Sustained release of the } \\
\text { hydrophilic lysozyme by passive } \\
\text { diffusion }\end{array}$ & {$[349]$} \\
\hline $\begin{array}{l}\text { N-methacryloyl-(L)-histidine } \\
\text { methylester }\end{array}$ & $\begin{array}{l}\text { S. aureus } \\
\text { E. coli }\end{array}$ & Complex & $\begin{array}{l}\text { Antibacterial coatings and tissue } \\
\text { engineering studies }\end{array}$ & {$[350]$} \\
\hline Avarone & $\begin{array}{l}\text { Gram-positive } \\
\text { Gram-negative }\end{array}$ & $\begin{array}{l}\text { Addition to the } \\
\text { quinone moiety }\end{array}$ & $\begin{array}{l}\text { Targeting the cell wall vehicle for } \\
\text { delivering the quinone }\end{array}$ & {$[351]$} \\
\hline Cisplatin analogues & $\begin{array}{c}\text { C. albicans } \\
\text { Cryptococcus neoformans }\end{array}$ & Complexes & Antifungal activity & {$[352]$} \\
\hline Pyridylbenzimidazole Au (III) & $\begin{array}{c}\text { C. albicans } \\
\text { Cryptococcus neoformans }\end{array}$ & Complexes & Antifungal activity & {$[353]$} \\
\hline Caffeine, dioctyl sulfosuccinate & $\begin{array}{l}\text { E. coli } \\
\text { P. aeruginosa } \\
\text { B. thuringensis }\end{array}$ & Colloidal complex & $\begin{array}{l}\text { Development of antimicrobial } \\
\text { colloidal systems }\end{array}$ & {$[354]$} \\
\hline Triclosan & $\begin{array}{c}\text { E. coli } \\
\text { P. aeruginosa } \\
\text { K. pneumoniae } \\
\text { S. typhimurium }\end{array}$ & Complex & $\begin{array}{l}\text { Delivery of phenolic drugs to } \\
\text { microbial cells in food and drug } \\
\text { systems }\end{array}$ & {$[355,356]$} \\
\hline Polyproline & $\begin{array}{c}\text { E. coli } \\
\text { P. aeruginosa }\end{array}$ & $\begin{array}{l}\text { Recombinant } \\
\text { DNA technique }\end{array}$ & Increase in hydrophobicity & {$[357]$} \\
\hline Pluronic F-127 & B. subtilis & $\begin{array}{l}\text { Reductive } \\
\text { amination }\end{array}$ & $\begin{array}{c}\text { Biological systems, including the } \\
\text { coating of biomaterials implant } \\
\text { surfaces }\end{array}$ & {$[358]$} \\
\hline Cinnamic aldehyde & E. coli & $\begin{array}{l}\text { Covalent } \\
\text { modification }\end{array}$ & Increased antibiotic spectrum & {$[359]$} \\
\hline \multicolumn{5}{|c|}{ REACTIONS of LYSOZYME CHAIN } \\
\hline Reaction & Microorganism & Reagent & Applications/Claimed Uses & Refs. \\
\hline Reduction & $\begin{array}{l}\text { S. aureus } \\
\text { E. coli } \\
\text { S. enteritidis }\end{array}$ & Sodium sulfite & $\begin{array}{l}\text { Increased hydrophobicity, } \\
\text { antibacterial agent in food } \\
\text { industry }\end{array}$ & {$[360]$} \\
\hline $\begin{array}{l}\text { Oxidation of tyrosine and } \\
\text { tryptophan }\end{array}$ & M. lysodeikticus & $\begin{array}{l}\text { Reactive oxygen } \\
\text { and nitrogen } \\
\text { species }\end{array}$ & $\begin{array}{l}\text { Treatment of cancer and } \\
\text { infectious diseases, antibacterial, } \\
\text { and disinfecting agent }\end{array}$ & {$[361]$} \\
\hline Oxidation & P. fluorescens & $\begin{array}{l}\text { Hydrogen } \\
\text { peroxide }\end{array}$ & Increased hydrophobicity & {$[362]$} \\
\hline Arylation & $\begin{array}{l}\text { S. aureus } \\
\text { S. epidermidis }\end{array}$ & $\begin{array}{l}\text { Arylation of } \\
\text { tryptophan } \\
\text { residues with } \\
\text { iodobenzene }\end{array}$ & Increased hydrophobicity & {$[363]$} \\
\hline
\end{tabular}




\subsection{Physical Modifications}

The thermal treatment of lysozyme is the most commonly reported physical process. By heating a lysozyme sample, the formation of oligomers, mainly the dimer, is, often, observed to be more active than the monomer. By subjecting the bacteria to high hydrostatic pressure, an improved sensitization to lysozyme can be achieved. The development of variants showing a modified charge on the protein chain, pave the way to an improved activity against Gram-negative bacteria, such as P. aeruginosa, evading the electrostatic inhibition by anionic biopolymers, associated with airway inflammation. The most interesting results about physical modifications are summarized in Table 8.

Table 8. Physical modifications of lysozyme.

\begin{tabular}{|c|c|c|c|}
\hline Physical Process & Microorganisms & Effect & Refs. \\
\hline $\begin{array}{l}\text { Microwave held followed by } \\
\text { oxidation }\end{array}$ & M. lysodeikticus & Dimer and trimer formation & [364] \\
\hline Microwave & M. lysodeikticus & $\begin{array}{c}\text { Dimer and trimer formation and } \\
\text { changes in surface } \\
\text { hydrophobicity }\end{array}$ & [365] \\
\hline $\begin{array}{l}\text { Fluorescens resonance energy } \\
\text { transfer }\end{array}$ & E. coli & Variants formation & [366] \\
\hline Cationic surfactant (gemini) & M. luteus & Micelles formation & [367] \\
\hline High hydrostatic pressure & $\begin{array}{l}\text { Gram-negative: E. coli, P. } \\
\text { fluorescens, S. entericas, S. sonnei, } \\
\text { and S. flexneri }\end{array}$ & Sensitization of bacteria & [101] \\
\hline High hydrostatic pressure & E. coli & $\begin{array}{l}\text { Increased outer membrane } \\
\text { permeability }\end{array}$ & [368] \\
\hline $\begin{array}{l}\text { Atmospheric and high } \\
\text { hydrostatic pressure }\end{array}$ & $\begin{array}{l}\text { Gram-positive } \\
\text { Gram-negative }\end{array}$ & Sensitization of bacteria & [369] \\
\hline Thermal treatment $\left(\mathrm{t} 80^{\circ} \mathrm{C}\right)$ & $\begin{array}{l}\text { M. luteus } \\
\text { E. coli }\end{array}$ & $\begin{array}{c}\text { Formation of dimer depending on } \\
\mathrm{pH} \text { and concentration }\end{array}$ & [370] \\
\hline $\begin{array}{l}\text { Thermochemical treatment }(60-70 \\
\left.{ }^{\circ} \mathrm{C}+10-20 \% \mathrm{H}_{2} \mathrm{O}_{2}\right)\end{array}$ & $\begin{array}{l}\text { M. lysodeikticus } \\
\text { S. epidermidis }\end{array}$ & Formation of dimer & [371] \\
\hline $\begin{array}{l}\text { Thermochemical treatment } \\
\text { (denaturation with heat or with } \\
\text { dithiothreitol) }\end{array}$ & $\begin{array}{l}\text { E. coli } \\
\text { S. carnosus }\end{array}$ & Oligomers formation & [372] \\
\hline Dry heating ( $80{ }^{\circ} \mathrm{C}, 7$ days) & E. coli & $\begin{array}{l}\text { Increased insertion capacity and } \\
\text { ability to induce lipid packing } \\
\text { modifications }\end{array}$ & [373] \\
\hline Heating of jenny milk & $\begin{array}{c}\text { B. megaterium } \\
\text { Clavibacter michiganensis } \\
\text { Clostridium tyrobutyricum } \\
\text { Xanthomonas campestris } \\
\text { E. coli }\end{array}$ & $\begin{array}{c}\text { Antimicrobial activity like } \\
\text { synthetic antibiotics against some } \\
\text { Gram-positive and } \\
\text { Gram-negative strains }\end{array}$ & [18] \\
\hline \multicolumn{4}{|l|}{ Bioengineered modifications: } \\
\hline $\begin{array}{l}\text { Net charge inversion of a phage } \\
\text { lysozyme }\end{array}$ & S. pneumoniae & Mutation of a Cpl-7 & [374] \\
\hline $\begin{array}{l}\text { Charge engineered variant of } \\
\text { hLys }\end{array}$ & P. aeruginosa & $\begin{array}{l}\text { Redesigned electrostatic potential } \\
\text { field }\end{array}$ & [375-377] \\
\hline
\end{tabular}

\section{Conclusions}

The impressive number of literature data, published in the last two decades, dealing with lysozyme antimicrobial activity clearly proves the great interest provoked by this well-known molecule. Lysozyme is often regarded as a potential help to overcome the 
problem of traditional antibiotic resistant bacterial infections. This interest explains the extensive research of lysozyme modifications to improve the applications in medicine, veterinary, crop production, feed, and food preservation.

Many works are focused on lysozyme engineering to penetrate the outer membrane, the main obstacle to its activity against Gram-negative bacteria. Modifications of the dense positive charge of hLys, defined as "Achilles' heel" in a 2011 article [377], can aid the development of novel therapeutic applications. Lysozyme containing coatings and thin films, obtained through nanotechnology approaches, can provide the response to the problem of food-borne pathogens or biofilm formation on medical devices. The availability of transgenic rice, expressing hLys, is a promising supplement source for infant formula, in breastfeeding difficulty or impossibility.

In conclusion, it appears appropriate to conclude this review with Alexander Fleming's famous quote: "We shall hear more about lysozyme" [378].

Author Contributions: Conceptualization, P.G. and P.F.; writing—original draft preparation, P.F. and P.G.; writing — review and editing, P.F., S.C. and P.G. All authors have read and agreed to the published version of the manuscript.

Funding: This research received no external funding.

Acknowledgments: The authors acknowledge Sophia Sforna for her help in the typing the text and Yuncai Gao (Abbotsford, BC, Canada) for English language revision.

Conflicts of Interest: The authors declare no conflict of interest.

\section{References}

1. Grishin, A.V.; Karyagina, A.S.; Vasina, D.V.; Vasina, I.V.; Gushchin, V.A.; Lunin, V.G. Resistance to peptidoglycan-degrading enzymes. Crit. Rev. Microbiol. 2020, 46, 703-726. [CrossRef] [PubMed]

2. Fleming, A. On a remarkable bacteriolytic element found in tissues and secretions. Proc. R. Soc. Lond. B 1922, 93, 6-317. [CrossRef]

3. Callewaert, L.; Michiels, C.W. Lysozymes in the animal kingdom. J. Biosci. 2010, 35, 127-160. [CrossRef] [PubMed]

4. Jollès, P.; Jollès, J. What's new in lysozyme research? Always a model system, today as yesterday. Mol. Cell. Biochem. 1984, 63, 165-189. [CrossRef]

5. Beintema, J.J.; van Scheltinga, A.C.T. Plant lysozymes. EXS 1996, 75, 75-86. [CrossRef]

6. Fastrez, J. Phage lysozymes. In Lysozymes: Model Enzymes in Biochemistry and Biology; Jollès, P., Ed.; Birkhäuser Basel: Basel, Switzerland, 1996; pp. 35-64. ISBN 978-3-0348-9952-9.

7. Barbara, L.; Pellegrini, R. Fleming's Lysozyme: Biological Significance and Therapeutic Applications; Edizioni Minerva Medica: Torino, Italy, 1976.

8. Wilcox, F.H.; Cole, R.K. The inheritance of differences in the lysozyme level of Hens' egg white. Genetics 1957, 42, $264-272$. [CrossRef] [PubMed]

9. Sauter, E.A.; Montoure, J.E. The relationship of lysozyme content of egg white to volume and stability of foams. J. Food Sci. 1972, 37, 918-920. [CrossRef]

10. Shahmohammadi, A. Lysozyme separation from chicken egg white: A review. Eur. Food Res. Technol. 2018, 244, 577-593. [CrossRef]

11. Lesnierowski, G.; Kijowski, J.; Cegielska-Radziejewska, R. Ultrafiltration-modified chicken egg white lysozyme and its antibacterial action. Int. J. Food Sci. 2009, 44, 305-311. [CrossRef]

12. Ahlborn, G.; Sheldon, B.W. Enzymatic and microbiological inhibitory activity in eggshell membranes as influenced by layer strains and age and storage variables. Poult. Sci. 2005, 84, 1935-1941. [CrossRef]

13. Kozuka, M.; Murao, S.; Yamane, T.; Inoue, T.; Ohkubo, I.; Ariga, H. Rapid and simple purification of lysozyme from the egg shell membrane. J. Nutr. Sci. Vitaminol. 2015, 61, 101-103. [CrossRef]

14. Gomathi, S.; Vijitha, M.; Rathnasamy, S. Affinity separation of lysozyme from quail egg (Coturnix ypsilophora) and its antimicrobial characterization. Int. J. PharmTech Res. 2014, 6, 1286.

15. Myint, S.L.; Kinoshita, K.; Shimogiri, T.; Ibrahim, H.R.; Tsusaki, T.; Tanoue, T.; Kawabe, K.; Maeda, Y.; Okamoto, S. Effect of polymorphism in egg white lysozyme on muramidase and antibacterial activities as well as hatchability in the Japanese quail (Coturnix japonica). J. Anim. Sci. 2012, 90, 1747-1755. [CrossRef] [PubMed]

16. Thammasirirak, S.; Pukcothanung, Y.; Preecharram, S.; Daduang, S.; Patramanon, R.; Fukamizo, T.; Araki, T. Antimicrobial peptides derived from goose egg white lysozyme. Comp. Biochem. Physiol. C Toxicol. Pharmacol. 2010, 151, 84-91. [CrossRef] [PubMed]

17. Benkerroum, N. Antimicrobial activity of lysozyme with special relevance to milk. Afr. J. Biotechnol. 2008, 7, 4856-4867. 
18. Cosentino, C.; Labella, C.; Elshafie, H.S.; Camele, I.; Musto, M.; Paolino, R.; D'Adamo, C.; Freschi, P. Effects of different heat treatments on lysozyme quantity and antimicrobial activity of jenny milk. J. Dairy Sci. 2016, 99, 5173-5179. [CrossRef] [PubMed]

19. Priyadarshini, S.; Kansal, V.K. Purification, characterization, antibacterial activity and N-terminal sequencing of buffalo-milk lysozyme. J. Dairy Res. 2002, 69, 419-431. [CrossRef]

20. Ibrahim, H.R.; Imazato, K.; Ono, H. Human lysozyme possesses novel antimicrobial peptides within its N-terminal domain that target bacterial respiration. J. Agric. Food Chem. 2011, 59, 10336-10345. [CrossRef] [PubMed]

21. Fleming, A.; Allison, V.D. Observations on a Bacteriolytic Substance ("Lysozyme") Found in Secretions and Tissues. Br. J. Exp. Pathol. 1922, 3, 252-260.

22. Fleming, A.; Allison, V.D. Further observations on a bacteriolytic element found in tissues and secretions. Proc. R. Soc. Lond. B 1922, 94, 142-151. [CrossRef]

23. Jolles, P. Chimie et Biochimie des Lysozymes: (1) Le Lysozyme de Blanc D'oeuf de Poule: Structure Chimique, Ponts Disulfures, Relations Entre Structure et Activité. (2) Etude Comparée de Quelques Lysozymes D'origines Diverses, 27th ed.; Masson: Paris, France, 1966.

24. Fábián, T.K.; Hermann, P.; Beck, A.; Fejérdy, P.; Fábián, G. Salivary defense proteins: Their network and role in innate and acquired oral immunity. Int. J. Mol. Sci. 2012, 13, 4295-4320. [CrossRef] [PubMed]

25. Liu, J.; Yi, C.; Ming, W.; Tang, M.; Tang, X.; Luo, C.; Lei, B.; Chen, M.; Xu, H. Retinal Pigment Epithelial Cells Express Antimicrobial Peptide Lysozyme-A Novel Mechanism of Innate Immune Defense of the Blood-Retina Barrier. Investig. Ophthalmol. Vis. Sci. 2021, 62, 21. [CrossRef] [PubMed]

26. Ben Bacha, A.; Abid, I. Secretory phospholipase A2 in dromedary tears: A host defense against staphylococci and other grampositive bacteria. Appl. Biochem. Biotechnol. 2013, 169, 1858-1869. [CrossRef] [PubMed]

27. Wei, J.; Li, S.-J.; Shi, H.; Wang, H.-Y.; Rong, C.-T.; Zhu, P.; Jin, S.-H.; Liu, J.; Li, J.-Y. Characterisation of Lyzls in mice and antibacterial properties of human LYZL6. Asian J. Androl. 2013, 15, 824-830. [CrossRef] [PubMed]

28. Irwin, D.M. Evolution of cow nonstomach lysozyme genes. Genome 2004, 47, 1082-1090. [CrossRef] [PubMed]

29. Jiang, M.; Chen, Y.; Wang, Y.; Loor, J.J.; Ye, Y.; Wen, Y.; Zi, X.; Cai, Y.; Drackley, J.K. Yak (Bos grunniens) stomach lysozyme: Molecular cloning, expression and its antibacterial activities. Anim. Biotechnol. 2010, 21, 25-35. [CrossRef] [PubMed]

30. Zhang, P.; Wang, Y.; Jiang, M.; Zhu, L.; Li, J.; Luo, M.; Ren, H.; Liu, L. Molecular cloning, recombinant protein expression, tissue distribution and functional analysis of a new c-type lysozyme from Lezhi black goat rumen. Can. J. Anim. Sci. 2014, 94, 27-34. [CrossRef]

31. Magnadottir, B.; Lange, S.; Gudmundsdottir, S.; Bøgwald, J.; Dalmo, R.A. Ontogeny of humoral immune parameters in fish. Fish Shellfish Immunol. 2005, 19, 429-439. [CrossRef]

32. Guardiola, F.A.; Cuesta, A.; Abellán, E.; Meseguer, J.; Esteban, M.A. Comparative analysis of the humoral immunity of skin mucus from several marine teleost fish. Fish Shellfish Immunol. 2014, 40, 24-31. [CrossRef]

33. Sridhar, A.; Krishnasamy Sekar, R.; Manikandan, D.B.; Arumugam, M.; Veeran, S.; Ramasamy, T. Activity profile of innate immune-related enzymes and bactericidal of freshwater fish epidermal mucus extract at different pH. Environ. Sci. Pollut. Res. Int. 2021, 28, 33914-33926. [CrossRef]

34. Whang, I.; Lee, Y.; Lee, S.; Oh, M.-J.; Jung, S.-J.; Choi, C.Y.; Lee, W.S.; Kim, H.S.; Kim, S.-J.; Lee, J. Characterization and expression analysis of a goose-type lysozyme from the rock bream Oplegnathus fasciatus, and antimicrobial activity of its recombinant protein. Fish Shellfish Immunol. 2011, 30, 532-542. [CrossRef] [PubMed]

35. Harikrishnan, R.; Kim, J.-S.; Kim, M.-C.; Balasundaram, C.; Heo, M.-S. Molecular characterization, phylogeny, and expression pattern of c-type lysozyme in kelp grouper, Epinephelus bruneus. Fish Shellfish Immunol. 2011, 31, 588-594. [CrossRef]

36. Zhao, L.; Sun, J.-S.; Sun, L. The g-type lysozyme of Scophthalmus maximus has a broad substrate spectrum and is involved in the immune response against bacterial infection. Fish Shellfish Immunol. 2011, 30, 630-637. [CrossRef] [PubMed]

37. Hinds Vaughan, N.; Smith, S.L. Isolation and characterization of a c-type lysozyme from the nurse shark. Fish Shellfish Immunol. 2013, 35, 1824-1828. [CrossRef] [PubMed]

38. Fu, G.H.; Bai, Z.Y.; Xia, J.H.; Liu, F.; Liu, P.; Yue, G.H. Analysis of two lysozyme genes and antimicrobial functions of their recombinant proteins in Asian seabass. PLoS ONE 2013, 8, e79743. [CrossRef] [PubMed]

39. Ko, J.; Wan, Q.; Bathige, S.D.N.K.; Lee, J. Molecular characterization, transcriptional profiling, and antibacterial potential of g-type lysozyme from seahorse (Hippocampus abdominalis). Fish Shellfish Immunol. 2016, 58, 622-630. [CrossRef]

40. Lee, J.M.; Kim, S.M. Biochemical and antibacterial properties of lysozyme purified from the viscera of scallops (Patinopecten yessoensis). J. Food Biochem. 2008, 32, 474-489. [CrossRef]

41. Korobov, V.P.; Lemkina, L.M.; Karnaukhova, I.V.; Poludova, T.V.; Solovykh, G.N.; Pavlova, M.M. Lysozyme of the bivalve mollusk Unio pictorum. Doklady. Biochem. Biophys. 2003, 391, 192-194. [CrossRef]

42. Yue, X.; Liu, B.; Xue, Q. An i-type lysozyme from the Asiatic hard clam Meretrix meretrix potentially functioning in host immunity. Fish Shellfish Immunol. 2011, 30, 550-558. [CrossRef] [PubMed]

43. Dai, W.; Wu, D.; Zhang, M.; Wen, C.; Xie, Y.; Hu, B.; Jian, S.; Zeng, M.; Tao, Z. Molecular cloning and functional characterization of a novel i-type lysozyme in the freshwater mussel Cristaria plicata. Microbiol. Immunol. 2015, 59, 744-755. [CrossRef] [PubMed]

44. Yang, D.; Wang, Q.; Chen, L.; Liu, Y.; Cao, R.; Wu, H.; Li, F.; Ji, C.; Cong, M.; Zhao, J. Molecular characterization and antibacterial activity of a phage-type lysozyme from the Manila clam, Ruditapes philippinarum. Fish Shellfish Immunol. 2017, 65, 17-24. [CrossRef] 
45. Ding, J.; Li, J.; Bao, Y.; Li, L.; Wu, F.; Zhang, G. Molecular characterization of a mollusk chicken-type lysozyme gene from Haliotis discus hannai Ino, and the antimicrobial activity of its recombinant protein. Fish Shellfish Immunol. 2011, 30, 163-172. [CrossRef] [PubMed]

46. De-la-Re-Vega, E.; García-Galaz, A.; Díaz-Cinco, M.E.; Sotelo-Mundo, R.R. White shrimp (Litopenaeus vannamei) recombinant lysozyme has antibacterial activity against Gram negative bacteria: Vibrio alginolyticus, Vibrio parahemolyticus and Vibrio cholerae Fish Shellfish Immunol. 2006, 20, 405-408. [CrossRef]

47. Chen, T.; Ren, C.; Wang, Y.; Luo, P.; Jiang, X.; Huang, W.; Chen, C.; Hu, C. Molecular cloning, inducible expression and antibacterial analysis of a novel i-type lysozyme (lyz-i2) in Pacific white shrimp, Litopenaeus vannamei. Fish Shellfish Immunol. 2016, 54, 197-203. [CrossRef]

48. Tyagi, A.; Khushiramani, R.; Karunasagar, I.; Karunasagar, I. Antivibrio activity of recombinant lysozyme expressed from black tiger shrimp, Penaeus monodon. Aquaculture 2007, 272, 246-253. [CrossRef]

49. Mai, W.; Hu, C. cDNA cloning, expression and antibacterial activity of lysozyme C in the blue shrimp (Litopenaeus stylirostris). Prog. Nat. Sci. 2009, 19, 837-844. [CrossRef]

50. Kaizu, A.; Fagutao, F.F.; Kondo, H.; Aoki, T.; Hirono, I. Functional analysis of C-type lysozyme in penaeid shrimp. J. Biol. Chem. 2011, 286, 44344-44349. [CrossRef] [PubMed]

51. Mai, W.; Hu, C. Molecular cloning, characterization, expression and antibacterial analysis of a lysozyme homologue from Fenneropenaeus merguiensis. Mol. Biol. Rep. 2009, 36, 1587-1595. [CrossRef] [PubMed]

52. Cong, L.; Yang, X.; Wang, X.; Tada, M.; Lu, M.; Liu, H.; Zhu, B. Characterization of an i-type lysozyme gene from the sea cucumber Stichopus japonicus, and enzymatic and nonenzymatic antimicrobial activities of its recombinant protein. J. Biosci. Bioeng. 2009, 107, 583-588. [CrossRef] [PubMed]

53. Kurdyumov, A.S.; Manuvera, V.A.; Baskova, I.P.; Lazarev, V.N. A comparison of the enzymatic properties of three recombinant isoforms of thrombolytic and antibacterial protein-Destabilase-Lysozyme from medicinal leech. BMC Biochem. 2015, 16, 27. [CrossRef] [PubMed]

54. Yudina, T.G.; Guo, D.; Piskunkova, N.F.; Pavlova, I.B.; Zavalova, L.L.; Baskova, I.P. Antifungal and antibacterial functions of medicinal leech recombinant destabilase-lysozyme and its heated-up derivative. Front. Chem. Sci. Eng. 2012, 6, 203-209. [CrossRef]

55. Fiołka, M.J.; Ptaszyńska, A.A.; Czarniawski, W. Antibacterial and antifungal lysozyme-type activity in Cameraria ohridella pupae. J. Invertebr. Pathol. 2005, 90, 1-9. [CrossRef] [PubMed]

56. Kajla, M.K.; Andreeva, O.; Gilbreath, T.M.; Paskewitz, S.M. Characterization of expression, activity and role in antibacterial immunity of Anopheles gambiae lysozyme c-1. Comp. Biochem. Physiol. B Biochem. Mol. Biol. 2010, 155, 201-209. [CrossRef] [PubMed]

57. Kim, J.-W.; Park, S.-I.; Yoe, J.; Yoe, S.M. Cloning and overexpression of lysozyme from Spodoptera litura in prokaryotic system. Anim. Cells Syst. 2011, 15, 29-36. [CrossRef]

58. Kim, J.-W.; Yoe, J.; Lee, G.H.; Yoe, S.M. Recombinant expression and refolding of the c-type lysozyme from Spodoptera litura in E. coli. Electron. J. Biotechnol. 2011, 14, 6. [CrossRef]

59. Park, S.-I.; Yoe, S.M. Overexpression and purification of recombinant lysozyme from Agrius convolvuli expressed as inclusion body in Escherichia coli. Anim. Cells Syst. 2012, 16, 455-461. [CrossRef]

60. Sowa-Jasiłek, A.; Zdybicka-Barabas, A.; Staczzek, S.; Wydrych, J.; Skrzypiec, K.; Mak, P.; Deryło, K.; Tchórzewski, M.; Cytryńska, M. Galleria mellonella lysozyme induces apoptotic changes in Candida albicans cells. Microbiol. Res. 2016, 193, 121-131. [CrossRef]

61. Mohrig, W.; Messner, B. Lysozym als antibakterielles Agens im Bienenhoig und Bienengift. Acta Biol. Med. Ger. 1968, 21, 85-95.

62. Israili, Z.H. Antimicrobial properties of honey. Am. J. Ther. 2014, 21, 304-323. [CrossRef]

63. Al-Jabri, A.A. Honey, milk and antibiotics. Afr. J. Biotechnol. 2005, 4. [CrossRef]

64. Wen, S.; Mao, T.-X.; Yao, D.-M.; Li, T.; Wang, F.-H. Yeast Surface Display of Antheraea pernyi Lysozyme Revealed $\alpha$-Helical Antibacterial Peptides in Its N-Terminal Domain. J. Agric. Food Chem. 2018, 66, 9138-9146. [CrossRef]

65. Wang, W.-X.; Wang, Y.-P.; Deng, X.-J.; Dang, X.-L.; Tian, J.-H.; Yi, H.-Y.; Li, Y.-F.; He, X.-F.; Cao, Y.; Xia, Q.-Y.; et al. Molecular and functional characterization of a c-type lysozyme from the Asian corn borer, Ostrinia furnacalis. J. Insect Sci. 2009, 9, 17. [CrossRef]

66. Huang, H.; Du, J.; Li, S.-W.; Gong, T. Identification and Functional Analysis of a Lysozyme Gene from Coridius chinensis (Hemiptera: Dinidoridae). Biology 2021, 10, 330. [CrossRef] [PubMed]

67. Wang, S.; Ng, T.B.; Chen, T.; Lin, D.; Wu, J.; Rao, P.; Ye, X. First report of a novel plant lysozyme with both antifungal and antibacterial activities. Biochem. Biophys. Res. Commun. 2005, 327, 820-827. [CrossRef] [PubMed]

68. Wang, S.; Ye, X.; Rao, P. Isolation of a novel leguminous lysozyme and study on the antifungal activity. Food Res. Int. 2012, 47, 341-347. [CrossRef]

69. Khémiri, I.; Essghaier, B.; Sadfi-Zouaoui, N.; Bitri, L. Antioxidant and Antimicrobial Potentials of Seed Oil from Carthamus tinctorius L. in the Management of Skin Injuries. Oxid. Med. Cell. Longev. 2020, 2020, 4103418. [CrossRef] [PubMed]

70. Pendzhiev, A.M. Proteolytic Enzymes of Papaya: Medicinal Applications. Pharm. Chem. J. 2002, 36, 315-317. [CrossRef]

71. Wang, S.; Shao, B.; Chang, J.; Rao, P. Isolation and identification of a plant lysozyme from Momordica charantia L. Eur. Food Res. Technol. 2011, 232, 613-619. [CrossRef]

72. Jin, M.; Zhang, T.; Zeng, R. DNA and Protein Sequences of Bacteriophage Lysozyme and Its Use for Preventing and Treating Bacterial Infection. Patent No. CN112662650, 16 April 2021. 
73. Liu, S.-T.; Saito, A.; Azakami, H.; Kato, A. Expression, purification, and characterization of an unstable lysozyme mutant in Pichia pastoris. Protein Expr. Purif. 2003, 27, 304-312. [CrossRef]

74. Hao, W.-J.; Li, G.-Q.; Xu, M.-Y.; Wei, Z.-R.; Chen, H.-M.; Liu, D.-H.; Ai, T.M. Induction and expression of T4 lysozyme gene in Pichia pastoris. J. Chin. Pharm. Sci. 2007, 16, 33.

75. Guan, C.; Wang, G.; Ji, J.; Wang, J.; Wang, H.; Tan, M. Bioencapsulation of living yeast (Pichia pastoris) with silica after transformation with lysozyme gene. J. Sol-Gel Sci. Technol. 2008, 48, 369-377. [CrossRef]

76. Zhang, H.; Fu, G.; Zhang, D. Cloning, characterization, and production of a novel lysozyme by different expression hosts. J. Microbiol. Biotechnol. 2014, 24, 1405-1412. [CrossRef] [PubMed]

77. van Kimmenade, A.; van Solingen, P.; Yao, J. Isolation of Lysozyme A from Trichoderma reesei for Use as Antimicrobial Agent in Detergents and Food Preservation. Patent No. WO2009102755, 20 August 2009.

78. Wang, Z.; Carter, D. Chalaropsis Lysozyme Protein and Its Use in Antibacterial Applications. Patent No. WO2005011587, 2 October 2005.

79. Ghasemi, S.; Ahmadian, G.; Sadeghi, M.; Zeigler, D.R.; Rahimian, H.; Ghandili, S.; Naghibzadeh, N.; Dehestani, A. First report of a bifunctional chitinase/lysozyme produced by Bacillus pumilus SG2. Enzyme Microb. Technol. 2011, 48, 225-231. [CrossRef]

80. Mandal, A.; Herr, J.C. Preparation of Active Human Lysozyme and Transgenic Organisms. Patent No. WO2006028497, 16 March 2006.

81. Ercan, D.; Demirci, A. Production of human lysozyme in biofilm reactor and optimization of growth parameters of Kluyveromyces lactis K7. Appl. Microbiol. Biotechnol. 2013, 97, 6211-6221. [CrossRef]

82. Benecky, M.J.; Frew, J.E.; Scowen, N.; Jones, P.; Hoffman, B.M. EPR and ENDOR detection of compound I from Micrococcus lysodeikticus catalase. Biochemistry 1993, 32, 11929-11933. [CrossRef]

83. Zhou, X.; Yu, Y.; Tao, J.; Yu, L. Production of LYZL6, a novel human c-type lysozyme, in recombinant Pichia pastoris employing high cell density fed-batch fermentation. J. Biosci. Bioeng. 2014, 118, 420-425. [CrossRef] [PubMed]

84. Gao, Y.; Zhao, H.L.; Feng, X.; Zhai, R.D.; Zhu, S.; DU, C.T.; Sun, C.J.; Lei, L.C. Expression of recombinant human lysozymetachyplesin I (hLYZ-TP I) in Pichia pastoris and analysis of antibacterial activity. Biomed. Environ. Sci. 2013, 26, 319-322. [CrossRef] [PubMed]

85. Yang, B.; Wang, J.; Tang, B.; Liu, Y.; Guo, C.; Yang, P.; Yu, T.; Li, R.; Zhao, J.; Zhang, L.; et al. Characterization of bioactive recombinant human lysozyme expressed in milk of cloned transgenic cattle. PLoS ONE 2011, 6, e17593. [CrossRef] [PubMed]

86. Kaiser, G.G.; Mucci, N.C.; González, V.; Sánchez, L.; Parrón, J.A.; Pérez, M.D.; Calvo, M.; Aller, J.F.; Hozbor, F.A.; Mutto, A.A. Detection of recombinant human lactoferrin and lysozyme produced in a bitransgenic cow. J. Dairy Sci. 2017, 100, 1605-1617. [CrossRef]

87. Liu, R.-Y.; Tian, T.T.; Liu, S.-H.; Huang, B.; Zhang, Y.-Y.; Hui, Y.-T. Study on Bovine Mammary Specific Expression Vector of Expressing Human Lysozyme Gene. J. Anim. Vet. Adv. 2012, 11, 1362-1367. [CrossRef]

88. Cheng, G. Targeting the human lysozyme gene on bovine $\alpha$ s1-casein gene locus in fibroblasts. Afr. J. Biotechnol. 2011, 10, 17323-17331. [CrossRef]

89. Wu, X.; Lin, Y.; Xi, Y.; Shao, Z.; Zhou, Y.; Liu, F.; Chen, H. The development of transgenic mice for the expression of large amounts of human lysozyme in milk. Biotechnol. Lett. 2014, 36, 1197-1202. [CrossRef] [PubMed]

90. Liu, S.; Li, X.; Lu, D.; Shang, S.; Wang, M.; Zheng, M.; Zhang, R.; Tang, B.; Li, Q.; Dai, Y.; et al. High-level expression of bioactive recombinant human lysozyme in the milk of transgenic mice using a modified human lactoferrin BAC. Transgenic Res. 2012, 21, 407-414. [CrossRef] [PubMed]

91. Yu, Z. Expression of recombinant human lysozyme in the milk of transgenic mice. Chin. Sci. Bull. 2003, 48, 2331. [CrossRef]

92. Yu, Z.; Meng, Q.; Yu, H.; Fan, B.; Yu, S.; Fei, J.; Wang, L.; Dai, Y.; Li, N. Expression and Bioactivity of Recombinant Human Lysozyme in the Milk of Transgenic Mice. J. Dairy Sci. 2006, 89, 2911-2918. [CrossRef]

93. Tong, J.; Wei, H.; Liu, X.; Hu, W.; Bi, M.; Wang, Y.; Li, Q.; Li, N. Production of recombinant human lysozyme in the milk of transgenic pigs. Transgenic Res. 2011, 20, 417-419. [CrossRef] [PubMed]

94. Carneiro, I.D.S.; de Menezes, J.N.R.; Maia, J.A.; Miranda, A.M.; de Oliveira, V.B.S.; Murray, J.D.; Maga, E.A.; Bertolini, M.; Bertolini, L.R. Milk from transgenic goat expressing human lysozyme for recovery and treatment of gastrointestinal pathogens. Eur. J. Pharm. Sci. 2018, 112, 79-86. [CrossRef] [PubMed]

95. Maga, E.A.; Desai, P.T.; Weimer, B.C.; Dao, N.; Kültz, D.; Murray, J.D. Consumption of lysozyme-rich milk can alter microbial fecal populations. Appl. Environ. Microbiol. 2012, 78, 6153-6160. [CrossRef]

96. Wu, H.; Cao, D.; Liu, T.; Zhao, J.; Hu, X.; Li, N. Purification and Characterization of Recombinant Human Lysozyme from Eggs of Transgenic Chickens. PLoS ONE 2015, 10, e0146032. [CrossRef] [PubMed]

97. Saarinen, K.M.; Juntunen-Backman, K.; Järvenpää, A.L.; Klemetti, P.; Kuitunen, P.; Lope, L.; Renlund, M.; Siivola, M.; Vaarala, O.; Savilahti, E. Breast-feeding and the development of cows' milk protein allergy. Adv. Exp. Med. Biol. 2000, 478, 121-130. [CrossRef] [PubMed]

98. Huang, J.; Wu, L.; Yalda, D.; Adkins, Y.; Kelleher, S.L.; Crane, M.; Lonnerdal, B.; Rodriguez, R.L.; Huang, N. Expression of functional recombinant human lysozyme in transgenic rice cell culture. Transgenic Res. 2002, 11, 229-239. [CrossRef] [PubMed]

99. Humphrey, B.D.; Huang, N.; Klasing, K.C. Rice expressing lactoferrin and lysozyme has antibiotic-like properties when fed to chicks. J. Nutr. 2002, 132, 1214-1218. [CrossRef] 
100. Ibrahim, H.R.; Matsuzaki, T.; Aoki, T. Genetic evidence that antibacterial activity of lysozyme is independent of its catalytic function. FEBS Lett. 2001, 506, 27-32. [CrossRef]

101. Masschalck, B.; van Houdt, R.; van Haver, E.G.; Michiels, C.W. Inactivation of gram-negative bacteria by lysozyme, denatured lysozyme, and lysozyme-derived peptides under high hydrostatic pressure. Appl. Environ. Microbiol. 2001, 67, 339-344. [CrossRef] [PubMed]

102. Ginsburg, I. Bactericidal cationic peptides can also function as bacteriolysis-inducing agents mimicking beta-lactam antibiotics? It is enigmatic why this concept is consistently disregarded. Med. Hypotheses 2004, 62, 367-374. [CrossRef] [PubMed]

103. Nash, J.A.; Ballard, T.N.S.; Weaver, T.E.; Akinbi, H.T. The peptidoglycan-degrading property of lysozyme is not required for bactericidal activity in vivo. J. Immunol. 2006, 177, 519-526. [CrossRef]

104. Woods, C.M.; Hooper, D.N.; Ooi, E.H.; Tan, L.-W.; Carney, A.S. Human lysozyme has fungicidal activity against nasal fungi. Am. J. Rhinol. Allergy 2011, 25, 236-240. [CrossRef] [PubMed]

105. Lee-Huang, S.; Huang, P.L.; Sun, Y.; Kung, H.F.; Blithe, D.L.; Chen, H.C. Lysozyme and RNases as anti-HIV components in beta-core preparations of human chorionic gonadotropin. Proc. Natl. Acad. Sci. USA 1999, 96, 2678-2681. [CrossRef]

106. Karachi, A.; Rajaian, H.; Aminlari, M.M.; Tabatabaee, A. Application of lysozyme and dextran conjugated lysozyme as natural antimicrobial agents in the treatment of experimental skin wound in mice. Int. J. Pharm. Sci. Res. 2013, 4, 4236. [CrossRef]

107. Öhlknecht, C.; Tegl, G.; Beer, B.; Sygmund, C.; Ludwig, R.; Guebitz, G.M. Cellobiose dehydrogenase and chitosan-based lysozyme responsive materials for antimicrobial wound treatment. Biotechnol. Bioeng. 2017, 114, 416-422. [CrossRef] [PubMed]

108. Abouhmad, A.; Mamo, G.; Dishisha, T.; Amin, M.A.; Hatti-Kaul, R. T4 lysozyme fused with cellulose-binding module for antimicrobial cellulosic wound dressing materials. J. Appl. Microbiol. 2016, 121, 115-125. [CrossRef] [PubMed]

109. Ravensdale, J.; Wood, F.; O’Brien, F.; Gregg, K. Investigations into methods to improve the antibacterial activity of Acticoat. J. Med. Microbiol. 2016, 65, 397-405. [CrossRef] [PubMed]

110. Tavakolian, M.; Okshevsky, M.; van de Ven, T.G.M.; Tufenkji, N. Developing Antibacterial Nanocrystalline Cellulose Using Natural Antibacterial Agents. ACS Appl. Mater. Interfaces 2018, 10, 33827-33838. [CrossRef] [PubMed]

111. Xiao, L.; Ni, W.; Zhao, X.; Guo, Y.; Li, X.; Wang, F.; Luo, G.; Zhan, R.; Xu, X. A moisture balanced antibacterial dressing loaded with lysozyme possesses antibacterial activity and promotes wound healing. Soft Matter 2021, 17, 3162-3173. [CrossRef]

112. Liao, A.-H.; Hung, C.-R.; Lin, C.-F.; Lin, Y.-C.; Chen, H.-K. Treatment effects of lysozyme-shelled microbubbles and ultrasound in inflammatory skin disease. Sci. Rep. 2017, 7, 41325. [CrossRef]

113. Cebrián, R.; Arévalo, S.; Rubiño, S.; Arias-Santiago, S.; Rojo, M.D.; Montalbán-López, M.; Martínez-Bueno, M.; Valdivia, E.; Maqueda, M. Control of Propionibacterium acnes by natural antimicrobial substances: Role of the bacteriocin AS- 48 and lysozyme. Sci. Rep. 2018, 8, 11766. [CrossRef] [PubMed]

114. Di Schiena, M.G.; Ferrari, S.; Rongen, R. Lysozyme Gel Formulations for Use as Disinfectants. U.S. Patent US20130259852, 3 October 2013.

115. Tan, H.; Jin, D.; Qu, X.; Liu, H.; Chen, X.; Yin, M.; Liu, C. A PEG-Lysozyme hydrogel harvests multiple functions as a fit-to-shape tissue sealant for internal-use of body. Biomaterials 2019, 192, 392-404. [CrossRef]

116. Ramiro-Gutiérrez, M.L.; Will, J.; Boccaccini, A.R.; Díaz-Cuenca, A. Reticulated bioactive scaffolds with improved textural properties for bone tissue engineering: Nanostructured surfaces and porosity. J. Biomed. Mater. Res. A 2014, 102, $2982-2992$. [CrossRef] [PubMed]

117. Pino-Ramos, V.H.; Flores-Rojas, G.G.; Alvarez-Lorenzo, C.; Concheiro, A.; Bucio, E. Graft copolymerization by ionization radiation, characterization, and enzymatic activity of temperature-responsive SR-g-PNVCL loaded with lysozyme. React. Funct. Polym. 2018, 126, 74-82. [CrossRef]

118. Yuan, M.; Dai, F.; Li, D.; Fan, Y.; Xiang, W.; Tao, F.; Cheng, Y.; Deng, H. Lysozyme/collagen multilayers layer-by-layer deposited nanofibers with enhanced biocompatibility and antibacterial activity. Mater. Sci. Eng. C Mater. Biol. Appl. 2020, $112,110868$. [CrossRef] [PubMed]

119. Al Meslmani, B.M.; Mahmoud, G.F.; Leichtweiß, T.; Strehlow, B.; Sommer, F.O.; Lohoff, M.D.; Bakowsky, U. Covalent immobilization of lysozyme onto woven and knitted crimped polyethylene terephthalate grafts to minimize the adhesion of broad spectrum pathogens. Mater. Sci. Eng. C Mater. Biol. Appl. 2016, 58, 78-87. [CrossRef] [PubMed]

120. Nezu, T.; Masuyama, T.; Sasaki, K.; Saitoh, S.; Taira, M.; Araki, Y. Effect of pH and addition of salt on the adsorption behavior of lysozyme on gold, silica, and titania surfaces observed by quartz crystal microbalance with dissipation monitoring. Dent. Mater. J. 2008, 27, 573-580. [CrossRef] [PubMed]

121. Li, H.; Gao, C.; Tang, L.; Wang, C.; Chen, Q.; Zheng, Q.; Yang, S.; Sheng, S.; Zan, X. Lysozyme (Lys), Tannic Acid (TA), and Graphene Oxide (GO) Thin Coating for Antibacterial and Enhanced Osteogenesis. ACS Appl. Bio Mater. 2020, 3, 673-684. [CrossRef]

122. He, L.; Cui, Y.; Zhang, C. The corrosion resistance, cytotoxicity, and antibacterial properties of lysozyme coatings on orthodontic composite arch wires. RSC Adv. 2020, 10, 18131-18137. [CrossRef]

123. Budny, J.A.; Budny, M.J. Compositions for Treating Biofilm. U.S. Patent US6830745, 14 December 2004.

124. Frank, K.L.; Rouchon, C.; Harris, J.A. Antibacterial Methods and Related Kits of Treating a Bacterial Infection Using Lysozyme. Patent No. WO2019018368, 24 January 2019.

125. Caro, A.; Humblot, V.; Méthivier, C.; Minier, M.; Salmain, M.; Pradier, C.-M. Grafting of lysozyme and/or poly(ethylene glycol) to prevent biofilm growth on stainless steel surfaces. J. Phys. Chem. B 2009, 113, 2101-2109. [CrossRef] [PubMed] 
126. Yuan, S.; Yin, J.; Jiang, W.; Liang, B.; Pehkonen, S.O.; Choong, C. Enhancing antibacterial activity of surface-grafted chitosan with immobilized lysozyme on bioinspired stainless steel substrates. Colloids Surf. B Biointerfaces 2013, 106, 11-21. [CrossRef]

127. Devlieghere, F.; Vermeulen, A.; Debevere, J. Chitosan: Antimicrobial activity, interactions with food components and applicability as a coating on fruit and vegetables. Food Microbiol. 2004, 21, 703-714. [CrossRef]

128. Díez-Martínez, R.; de Paz, H.D.; García-Fernández, E.; Bustamante, N.; Euler, C.W.; Fischetti, V.A.; Menendez, M.; García, P. A novel chimeric phage lysin with high in vitro and in vivo bactericidal activity against Streptococcus pneumoniae. J. Antimicrob. Chemother. 2015, 70, 1763-1773. [CrossRef] [PubMed]

129. Ren, W.; Wang, S.; Lü, M.; Wang, X.; Fang, Y.; Jiao, Y.; Hu, J. Optimization of four types of antimicrobial agents to increase the inhibitory ability of marine Arthrobacter oxydans KQ11 dextranase mouthwash. Chin. J. Ocean. Limnol. 2016, 34, 354-366. [CrossRef]

130. Okamoto, I.; Miyaji, H.; Miyata, S.; Shitomi, K.; Sugaya, T.; Ushijima, N.; Akasaka, T.; Enya, S.; Saita, S.; Kawasaki, H. Antibacterial and Antibiofilm Photodynamic Activities of Lysozyme-Au Nanoclusters/Rose Bengal Conjugates. ACS Omega 2021, 6, 9279-9290. [CrossRef]

131. Zhong, X.; Song, Y.; Yang, P.; Wang, Y.; Jiang, S.; Zhang, X.; Li, C. Titanium Surface Priming with Phase-Transited Lysozyme to Establish a Silver Nanoparticle-Loaded Chitosan/Hyaluronic Acid Antibacterial Multilayer via Layer-by-Layer Self-Assembly. PLoS ONE 2016, 11, e0146957. [CrossRef] [PubMed]

132. Guan, B.; Wang, H.; Xu, R.; Zheng, G.; Yang, J.; Liu, Z.; Cao, M.; Wu, M.; Song, J.; Li, N.; et al. Establishing Antibacterial Multilayer Films on the Surface of Direct Metal Laser Sintered Titanium Primed with Phase-Transited Lysozyme. Sci. Rep. 2016, 6, 36408. [CrossRef]

133. Sebaa, S.; Hizette, N.; Boucherit-Otmani, Z.; Courtois, P. Dose-dependent effect of lysozyme upon Candida albicans biofilm. Mol. Med. Rep. 2017, 15, 1135-1142. [CrossRef] [PubMed]

134. Kehail, A.A.; Brigham, C.J. Anti-biofilm Activity of Solvent-Cast and Electrospun Polyhydroxyalkanoate Membranes Treated with Lysozyme. J. Polym. Environ. 2018, 26, 66-72. [CrossRef]

135. Hou, Y.; Wang, Z.; Zhang, P.; Bai, H.; Sun, Y.; Duan, J.; Mu, H. Lysozyme Associated Liposomal Gentamicin Inhibits Bacterial Biofilm. Int. J. Mol. Sci. 2017, 18, 784. [CrossRef] [PubMed]

136. Eladawy, M.; El-Mowafy, M.; El-Sokkary, M.M.A.; Barwa, R. Effects of Lysozyme, Proteinase K, and Cephalosporins on Biofilm Formation by Clinical Isolates of Pseudomonas aeruginosa. Interdiscip. Perspect. Infect. Dis. 2020, 2020, 6156720. [CrossRef]

137. Komal, S.; Abhishek, P.; Mansi, S.; Shilpa, G. Synergistic Effect of Antibiotics and Enzymes as Strategies for Combating Biofilm Formation by Pseudomonas aeruginosa Pao1. Int. J. Pharma. Bio Sci. 2020, 11, 168-178. [CrossRef]

138. Thellin, O.; Zorzi, W.; Zorzi, D.; Delvenne, P.; Heinen, E.; ElMoualij, B.; Quatresooz, P. Lysozyme as a cotreatment during antibiotics use against vaginal infections: An in vitro study on Gardnerella vaginalis biofilm models. Int. Microbiol. 2016, 19, 101-107. [CrossRef]

139. Singh, A.; Verma, A.; Singh, R.; Sahoo, A.K.; Samanta, S.K. Combination therapy of biogenic C-dots and lysozyme for enhanced antibacterial and antibiofilm activity. Nanotechnology 2021, 32, 85104. [CrossRef] [PubMed]

140. Zhang, Y. Oral Care Solution Containing Lysozyme and Preparation Method Thereof. Patent No. CN112933217, 11 June 2021.

141. Tong, H.; Xu, Z. Preparation Method of Stain-Removing Whitening Biological Lysozyme Toothpaste Composition and Application. Patent No. CN112773727, 11 May 2021.

142. Zhang, J. Composite Oral Spray Containing Lysozyme and Its Preparation Method. Patent No. CN112741900, 4 May 2021.

143. Zhang, X.; Que, K.; Lu, D.; Wu, J.; Zhang, X. Anti-Biomembrane-Remineralization Material for Root Canal Irrigation and Blocking Treatment of Dentin Caries and Preparation Method Thereof. Patent No. CN112716812, 30 April 2021.

144. Hu, W.; Liu, B.; Hu, H.; Tian, Q.; Mao, E.; Wu, X. Oral Cavity Care Spray Containing Lysozyme for Dog and Cat without Toxic and Side Effects and Preparation Method Thereof. Patent No. CN112315842, 5 February 2021.

145. Hong, J.-Y.; Lee, J.-S.; Choi, S.-H.; Shin, H.-S.; Park, J.-C.; Shin, S.-I.; Chung, J.-H. A randomized, double-blind, placebo-controlled multicenter study for evaluating the effects of fixed-dose combinations of vitamin C, vitamin E, lysozyme, and carbazochrome on gingival inflammation in chronic periodontitis patients. BMC Oral Health 2019, 19, 40. [CrossRef] [PubMed]

146. de Andrade, F.B.; de Oliveira, J.C.; Yoshie, M.T.; Guimarães, B.M.; Gonçalves, R.B.; Schwarcz, W.D. Antimicrobial activity and synergism of lactoferrin and lysozyme against cariogenic microorganisms. Braz. Dent. J. 2014, 25, 165-169. [CrossRef] [PubMed]

147. Pinheiro, S.L.; Azenha, G.R.; de Milito, F.; Democh, Y.M. Antimicrobial Capacity of Casein Phosphopeptide/Amorphous Calcium Phosphate and Enzymes in Glass Ionomer Cement in Dentin Carious Lesions. Acta Stomatol. Croat. 2015, 49, 104-111. [CrossRef]

148. van Nieuw Amerongen, A.; Bolscher, J.G.M.; Veerman, E.C.I. Salivary proteins: Protective and diagnostic value in cariology? Caries Res. 2004, 38, 247-253. [CrossRef] [PubMed]

149. Cantor, J.O.; Shteyngart, B. Intratracheal Administration of Lysozyme. U.S. Patent US20010036443, 1 November 2001.

150. Shteyngart, B. Intratracheal Administration of Lysozyme with Other Therapeutic Agents in the Prevention and Treatment of Respiratory Disorders. U.S. Patent US20050271645, 8 December 2005.

151. Bhavsar, T.; Liu, M.; Hardej, D.; Liu, X.; Cantor, J. Aerosolized recombinant human lysozyme ameliorates Pseudomonas aeruginosainduced pneumonia in hamsters. Exp. Lung Res. 2010, 36, 94-100. [CrossRef] [PubMed]

152. Weaver, T.E.; Akinbi, H.T. Lysozyme and Surfactant Protein B Fusion Protein for Treatment of Bacterial Infections. Patent No. WO2000029588, 25 May 2000. 
153. Wong, G.C.L.; Xian, W.; Sanders, L.K.; Purdy, K.R. Charge-Modified Lysozyme Antimicrobial Compositions, Surfactants, and Methods for Treating Infections in Cystic Fibrosis. Patent No. WO2007053800, 10 May 2007.

154. Guáqueta, C.; Sanders, L.K.; Wong, G.C.L.; Luijten, E. The effect of salt on self-assembled actin-lysozyme complexes. Biophys. J. 2006, 90, 4630-4638. [CrossRef]

155. Mohammadinejad, S.; Ghamkhari, B.; Abdolmaleki, S. Stability of actin-lysozyme complexes formed in cystic fibrosis disease. Soft Matter 2016, 12, 6557-6565. [CrossRef] [PubMed]

156. Mogna, G. Composition Comprising N-Acetylcysteine and/or Microencapsulated Gastroprotected Lysozyme in Association with Probiotic Bacteria Capable of Restoring the Stomach's Own Barrier Effect Which Is Lost during the Pharmacological Treatment of Gastric Hyperacidity. U.S. Patent US20140328932, 6 November 2014.

157. Kjaerulff, S.; Cohn, M.T.; Kristensen, N.N. Microbial Lysozyme for Use in the Treatment of Irritable Bowel Syndrome or Inflammatory Bowel Disease. Patent No. WO2018127532, 12 July 2018.

158. Abimuldina, S.T.; Koftanyuk, N.V.; Kapshakbayeva, Z.V.; Temerbayeva, M.V.; Zhumankulova, E.N. Developing Domestic Food Additive. Indian J. Sci. Technol. 2016, 9, 97656. [CrossRef]

159. Bugla-Płoskońska, G.; Kiersnowski, A.; Futoma-Kołoch, B.; Doroszkiewicz, W. Killing of Gram-negative bacteria with normal human serum and normal bovine serum: Use of lysozyme and complement proteins in the death of Salmonella strains O48. Microb. Ecol. 2009, 58, 276-289. [CrossRef] [PubMed]

160. Ferrari, S. Novel Ophthalmic Compositions Containing Human Recombinant Lysozyme and Use Thereof for Treating Eye Conditions and as Contact Lens Solutions. U.S. Patent US20080213188, 4 September 2008.

161. Wang, B.; Lin, Q.; Jin, T.; Shen, C.; Tang, J.; Han, Y.; Chen, H. Surface modification of intraocular lenses with hyaluronic acid and lysozyme for the prevention of endophthalmitis and posterior capsule opacification. RSC Adv. 2015, 5, 3597-3604. [CrossRef]

162. Shimada, J.; Moon, S.K.; Lee, H.-Y.; Takeshita, T.; Pan, H.; Woo, J.-I.; Gellibolian, R.; Yamanaka, N.; Lim, D.J. Lysozyme M deficiency leads to an increased susceptibility to Streptococcus pneumoniae-induced otitis media. BMC Infect. Dis. 2008, 8, 134. [CrossRef] [PubMed]

163. Lim, D.J.; Lee, H.-Y.; Webster, P.; Andalibi, A.; Li, J.-D.; Ganz, T.; Cha, K. Use of Antimicrobial Proteins and Peptides for the Treatment of Otitis Media and Paranasal Sinusitis. U.S. Patent US20060034820, 16 February 2006.

164. Lee, M.; Kovacs-Nolan, J.; Yang, C.; Archbold, T.; Fan, M.Z.; Mine, Y. Hen egg lysozyme attenuates inflammation and modulates local gene expression in a porcine model of dextran sodium sulfate (DSS)-induced colitis. J. Agric. Food Chem. 2009, 57, 2233-2240. [CrossRef] [PubMed]

165. Lee, W.; Ku, S.-K.; Na, D.H.; Bae, J.-S. Anti-Inflammatory Effects of Lysozyme against HMGB1 in Human Endothelial Cells and in Mice. Inflammation 2015, 38, 1911-1924. [CrossRef] [PubMed]

166. Bergamo, A.; Gerdol, M.; Pallavicini, A.; Greco, S.; Schepens, I.; Hamelin, R.; Armand, F.; Dyson, P.J.; Sava, G. Lysozyme-Induced Transcriptional Regulation of TNF- $\alpha$ Pathway Genes in Cells of the Monocyte Lineage. Int. J. Mol. Sci. 2019, 20, 5502. [CrossRef]

167. D'Incecco, P.; Gatti, M.; Hogenboom, J.A.; Bottari, B.; Rosi, V.; Neviani, E.; Pellegrino, L. Lysozyme affects the microbial catabolism of free arginine in raw-milk hard cheeses. Food Microbiol. 2016, 57, 16-22. [CrossRef] [PubMed]

168. Carrillo, W.; García-Ruiz, A.; Recio, I.; Moreno-Arribas, M.V. Antibacterial activity of hen egg white lysozyme modified by heat and enzymatic treatments against oenological lactic acid bacteria and acetic acid bacteria. J. Food Prot. 2014, 77, 1732-1739. [CrossRef]

169. van Landschoot, A.; Villa, A. Antibacterial properties of hen egg white lysozyme against beer spoilage bacteria and effect of lysozyme on yeast fermentation. Cerevisia 2008, 32, 219-224.

170. Li, Q.; Xu, J.; Zhang, D.; Zhong, K.; Sun, T.; Li, X.; Li, J. Preparation of a bilayer edible film incorporated with lysozyme and its effect on fish spoilage bacteria. J. Food Saf. 2020, 40, e12832. [CrossRef]

171. Park, S.-I.; Daeschel, M.A.; Zhao, Y. Functional Properties of Antimicrobial Lysozyme-Chitosan Composite Films. J. Food Sci. 2004, 69, M215-M221. [CrossRef]

172. Amiri, S.; Ramezani, R.; Aminlari, M. Antibacterial activity of dextran-conjugated lysozyme against Escherichia coli and Staphylococcus aureus in cheese curd. J. Food Prot. 2008, 71, 411-415. [CrossRef] [PubMed]

173. Amara, C.B.; Eghbal, N.; Oulahal, N.; Degraeve, P.; Gharsallaoui, A. Properties of lysozyme/sodium alginate complexes for the development of antimicrobial films. Food Res. Int. 2016, 89, 272-280. [CrossRef]

174. Wu, T.; Wu, C.; Fu, S.; Wang, L.; Yuan, C.; Chen, S.; Hu, Y. Integration of lysozyme into chitosan nanoparticles for improving antibacterial activity. Carbohydr. Polym. 2017, 155, 192-200. [CrossRef] [PubMed]

175. Li, X.; Tu, H.; Huang, M.; Chen, J.; Shi, X.; Deng, H.; Wang, S.; Du, Y. Incorporation of lysozyme-rectorite composites into chitosan films for antibacterial properties enhancement. Int. J. Biol. Macromol. 2017, 102, 789-795. [CrossRef]

176. Hashemi, M.; Aminlari, M.; Forouzan, M.; Moghimi, E.; Tavana, M.; Shekarforoush, S.; Mohammadifar, M. Production and Application of Lysozyme-Gum Arabic Conjugate in Mayonnaise as a Natural Preservative and Emulsifier. Pol. J. Food Nutr. Sci. 2018, 68, 33-43. [CrossRef]

177. Xu, Y.; Yin, Y.; Li, T.; Zhao, H.; Li, X.; Li, J.; Sun, T. Effects of lysozyme combined with cinnamaldehyde on storage quality of olive flounder (Paralichthys olivaceus) fillets. J. Food Sci. 2020, 85, 1037-1044. [CrossRef] [PubMed]

178. Palotás, P.; Jónás, G.; Lehel, J.; Friedrich, L. Preservative Effect of Novel Combined Treatment with Electrolyzed Active Water and Lysozyme Enzyme to Increase the Storage Life of Vacuum-Packaged Carp. J. Food Qual. 2020, 2020, 4861471. [CrossRef] 
179. Cegielska-Radziejewska, R.; Szablewski, T.; Radziejewska-Kubzdela, E.; Tomczyk, Ł.; Biadała, A.; Leśnierowski, G. The Effect of Modified Lysozyme Treatment on the Microflora, Physicochemical and Sensory Characteristics of Pork Packaged in Preservative Gas Atmospheres. Coatings 2021, 11, 488. [CrossRef]

180. López-Pedemonte, T.J.; Roig-Sagués, A.X.; Trujillo, A.J.; Capellas, M.; Guamis, B. Inactivation of Spores of Bacillus cereus in Cheese by High Hydrostatic Pressure with the Addition of Nisin or Lysozyme. J. Dairy Sci. 2003, 86, 3075-3081. [CrossRef]

181. Cannarsi, M.; Baiano, A.; Sinigaglia, M.; Ferrara, L.; Baculo, R.; Del Nobile, M.A. Use of nisin, lysozyme and EDTA for inhibiting microbial growth in chilled buffalo meat. Int. J. Food Sci. 2008, 43, 573-578. [CrossRef]

182. Apriliyani, M.W.; Rosyidi, D.; Purwadi, P.; Purnomo, H.; Manab, A. The Release of Egg White Lysozyme Containing EDTA from Composite Edible Film Based on Whey Protein, Konjac Flour and Lipid. Adv. J. Food Sci. Technol. 2014, 6, 48-55. [CrossRef]

183. Rao, M.S.; Chander, R.; Sharma, A. Synergistic effect of chitooligosaccharides and lysozyme for meat preservation. LWT-Food Sci. Technol. 2008, 41, 1995-2001. [CrossRef]

184. Huang, W.; Xu, H.; Xue, Y.; Huang, R.; Deng, H.; Pan, S. Layer-by-layer immobilization of lysozyme-chitosan-organic rectorite composites on electrospun nanofibrous mats for pork preservation. Food Res. Int. 2012, 48, 784-791. [CrossRef]

185. Bhatia, S.; Bharti, A. Evaluating the antimicrobial activity of Nisin, Lysozyme and Ethylenediaminetetraacetate incorporated in starch based active food packaging film. J. Food Sci. Technol. 2015, 52, 3504-3512. [CrossRef]

186. Ananou, S.; Rivera, S.; Madrid, M.I.; Maqueda, M.; Martínez-Bueno, M.; Valdivia, E. Application of enterocin AS-48 as biopreservative in eggs and egg fractions: Synergism through lysozyme. LWT 2018, 89, 409-417. [CrossRef]

187. Khodanazary, A. Quality characteristics of refrigerated mackerel Scomberomorus commerson using gelatin-polycaprolactone composite film incorporated with lysozyme and pomegranate peel extract. Int. J. Food Prop. 2019, 22, 2057-2071. [CrossRef]

188. Lucero Estrada, C.S.; Del Carmen Velázquez, L.; de Guzmán, A.M.S. Effects of organic acids, nisin, lysozyme and EDTA on the survival of Yersinia enterocolitica population in inoculated orange beverages. J. Food Saf. 2010, 30, 24-39. [CrossRef]

189. Landers, T.F.; Cohen, B.; Wittum, T.E.; Larson, E.L. A review of antibiotic use in food animals: Perspective, policy, and potential. Public Health Rep. 2012, 127, 4-22. [CrossRef] [PubMed]

190. Casewell, M.; Friis, C.; Marco, E.; McMullin, P.; Phillips, I. The European ban on growth-promoting antibiotics and emerging consequences for human and animal health. J. Antimicrob. Chemother. 2003, 52, 159-161. [CrossRef] [PubMed]

191. Fan, Q.; Abouelezz, K.F.M.; Li, L.; Gou, Z.; Wang, Y.; Lin, X.; Ye, J.; Jiang, S. Influence of Mushroom Polysaccharide, Nano-Copper, Copper Loaded Chitosan, and Lysozyme on Intestinal Barrier and Immunity of LPS-mediated Yellow-Feathered Chickens. Animals 2020, 10, 594. [CrossRef] [PubMed]

192. Xia, Y.; Kong, J.; Zhang, G.; Zhang, X.; Seviour, R.; Kong, Y. Effects of dietary supplementation with lysozyme on the structure and function of the cecal microbiota in broiler chickens. PLoS ONE 2019, 14, e0216748. [CrossRef] [PubMed]

193. Liu, D.; Guo, Y.; Wang, Z.; Yuan, J. Exogenous lysozyme influences Clostridium perfringens colonization and intestinal barrier function in broiler chickens. Avian Pathol. 2010, 39, 17-24. [CrossRef]

194. Gong, M.; Anderson, D.; Rathgeber, B.; MacIsaac, J. The effect of dietary lysozyme with EDTA on growth performance and intestinal microbiota of broiler chickens in each period of the growth cycle. J. Appl. Poult. Res. 2017, 26, 1-8. [CrossRef]

195. Smith, S.R.; Ritchie, S.J.; Zhang, G. Antimicrobial Compositions Containing Lysozyme and Method for. Use. Patent No. WO2004026334, 1 April 2004.

196. Zhao, P.; Cao, D.; Xiao, H.; Li, X.; Huang, Y.; Jiang, L.; Gan, X.; Deng, J.; Chen, Q.; Wen, X.; et al. Bacteriostatic Animal Growth Promoter Containing Recombinant Human Lysozyme and Application Thereof. Patent No. CN112515050, 19 March 2021.

197. Oliver, W.T.; Wells, J.E. Lysozyme as an alternative to growth promoting antibiotics in swine production. J. Anim. Sci. Biotechnol. 2015, 6, 35. [CrossRef]

198. Vanrolleghem, W.; Tanghe, S.; Verstringe, S.; Bruggeman, G.; Papadopoulos, D.; Trevisi, P.; Zentek, J.; Sarrazin, S.; Dewulf, J. Potential dietary feed additives with antibacterial effects and their impact on performance of weaned piglets: A meta-analysis. Vet. J. 2019, 249, 24-32. [CrossRef] [PubMed]

199. Xu, B.; Fu, J.; Zhu, L.; Li, Z.; Jin, M.; Wang, Y. Overall assessment of antibiotic substitutes for pigs: A set of meta-analyses. J. Anim. Sci. Biotechnol. 2021, 12, 3. [CrossRef] [PubMed]

200. Nyachoti, C.M.; Kiarie, E.; Bhandari, S.K.; Zhang, G.; Krause, D.O. Weaned pig responses to Escherichia coli K88 oral challenge when receiving a lysozyme supplement. J. Anim. Sci. 2012, 90, 252-260. [CrossRef]

201. May, K.D.; Wells, J.E.; Maxwell, C.V.; Oliver, W.T. Granulated lysozyme as an alternative to antibiotics improves growth performance and small intestinal morphology of 10-day-old pigs. J. Anim. Sci. 2012, 90, 1118-1125. [CrossRef] [PubMed]

202. Oliver, W.T.; Wells, J.E. Lysozyme as an alternative to antibiotics improves growth performance and small intestinal morphology in nursery pigs. J. Anim. Sci. 2013, 91, 3129-3136. [CrossRef] [PubMed]

203. Wells, J.E.; Berry, E.D.; Kalchayanand, N.; Rempel, L.A.; Kim, M.; Oliver, W.T. Effect of lysozyme or antibiotics on faecal zoonotic pathogens in nursery pigs. J. Appl. Microbiol. 2015, 118, 1489-1497. [CrossRef] [PubMed]

204. Long, Y.; Lin, S.; Zhu, J.; Pang, X.; Fang, Z.; Lin, Y.; Che, L.; Xu, S.; Li, J.; Huang, Y.; et al. Effects of dietary lysozyme levels on growth performance, intestinal morphology, non-specific immunity and mRNA expression in weanling piglets. Anim. Sci. J. 2016, 87, 411-418. [CrossRef]

205. Zou, L.; Xiong, X.; Liu, H.; Zhou, J.; Liu, Y.; Yin, Y. Effects of dietary lysozyme levels on growth performance, intestinal morphology, immunity response and microbiota community of growing pigs. J. Sci. Food Agric. 2019, 99, 1643-1650. [CrossRef] [PubMed] 
206. Oliver, W.T.; Wells, J.E.; Maxwell, C.V. Lysozyme as an alternative to antibiotics improves performance in nursery pigs during an indirect immune challenge. J. Anim. Sci. 2014, 92, 4927-4934. [CrossRef] [PubMed]

207. Zhou, J.; Xiong, X.; Zou, L.; Yin, J.; Wang, K.; Shao, Y.; Yin, Y. Dietary lysozyme supplement alters serum biochemical makers and milk metabolite profile of sows via gut microbiota. bioRxiv 2018, 444778. [CrossRef]

208. Park, J.H.; Sureshkumar, S.; Kim, I.H. Effects of dietary lysozyme supplementation on growth performance, nutrient digestibility, intestinal microbiota, and blood profiles of weanling pigs challenged with Escherichia coli. J. Anim. Sci. Technol. 2021, 63, 501-509. [CrossRef] [PubMed]

209. Huang, G.; Li, X.; Lu, D.; Liu, S.; Suo, X.; Li, Q.; Li, N. Lysozyme improves gut performance and protects against enterotoxigenic Escherichia coli infection in neonatal piglets. Vet. Res. 2018, 49, 20. [CrossRef] [PubMed]

210. Cui, D.; Li, J.; Zhang, L.; Liu, S.; Wen, X.; Li, Q.; Zhao, Y.; Hu, X.; Zhang, R.; Li, N. Generation of bi-transgenic pigs overexpressing human lactoferrin and lysozyme in milk. Transgenic Res. 2015, 24, 365-373. [CrossRef]

211. Rathi, C.L.; Risbud, S.P.; Manohar, B.M. Novel Compositions Comprising Lysozyme and Serratiopeptidase for Prevention and Treatment of Mastitis and Metritis. Patent No. WO2008035370, 27 March 2008.

212. Ye, G.; Huang, Q. Biological Enzyme Disinfectant Preparation and Preparation Method Thereof. Patent No. CN112999337, 22 June 2021.

213. Smulski, S.; Gehrke, M.; Libera, K.; Cieslak, A.; Huang, H.; Patra, A.K.; Szumacher-Strabel, M. Effects of various mastitis treatments on the reproductive performance of cows. BMC Vet. Res. 2020, 16, 99. [CrossRef] [PubMed]

214. Sun, H.; Xue, F.; Qian, K.; Fang, H.; Qiu, H.; Zhang, X.; Yin, Z. Intramammary expression and therapeutic effect of a human lysozyme-expressing vector for treating bovine mastitis. J. Zhejiang Univ. Sci. B 2006, 7, 324-330. [CrossRef]

215. Adduci, F.; Elshafie, H.S.; Labella, C.; Musto, M.; Freschi, P.; Paolino, R.; Ragni, M.; Cosentino, C. Abatement of the clostridial load in the teats of lactating cows with lysozyme derived from donkey milk. J. Dairy Sci. 2019, 102, 6750-6755. [CrossRef] [PubMed]

216. Małaczewska, J.; Kaczorek-Łukowska, E.; Wójcik, R.; Siwicki, A.K. Antiviral effects of nisin, lysozyme, lactoferrin and their mixtures against bovine viral diarrhoea virus. BMC Vet. Res. 2019, 15, 318. [CrossRef]

217. Kumaresan, V.; Bhatt, P.; Ganesh, M.-R.; Harikrishnan, R.; Arasu, M.; Al-Dhabi, N.A.; Pasupuleti, M.; Marimuthu, K.; Arockiaraj, J. A novel antimicrobial peptide derived from fish goose type lysozyme disrupts the membrane of Salmonella enterica. Mol. Immunol. 2015, 68, 421-433. [CrossRef] [PubMed]

218. Verlhac, V. Feed Additives for Aquatic Animals Comprising Essential Oils and Lysozyme. Patent No. WO2017064092, 20 April 2017.

219. Yousefi, M.; Vatnikov, Y.A.; Kulikov, E.V.; Plushikov, V.G.; Drukovsky, S.G.; Hoseinifar, S.H.; van Doan, H. The protective effects of dietary garlic on common carp (Cyprinus carpio) exposed to ambient ammonia toxicity. Aquaculture 2020, 526, 735400. [CrossRef]

220. Elayaraja, S.; Mabrok, M.; Algammal, A.; Sabitha, E.; Rajeswari, M.V.; Zágoršek, K.; Ye, Z.; Zhu, S.; Rodkhum, C. Potential influence of jaggery-based biofloc technology at different C:N ratios on water quality, growth performance, innate immunity, immune-related genes expression profiles, and disease resistance against Aeromonas hydrophila in Nile tilapia (Oreochromis niloticus). Fish Shellfish Immunol. 2020, 107, 118-128. [CrossRef] [PubMed]

221. El-Deep, M.H.; Amber, K.A.; Eid, Y.Z.; Aboelenin, S.M.; Soliman, M.M.; Sakr, M.S.; Dawood, M.A.O. The Influence of Chicken Egg Lysozyme or Zinc-Bacitracin Antibiotic on the Growth Performance, Antibacterial Capacity, Blood Profiles, and Antioxidative Status of Rabbits: A Comparative Study. Animals 2021, 11, 1731. [CrossRef] [PubMed]

222. Wackernagel, W.; Duering, K. Transgenic potato plants expressing antimicrobial activity: Establishment of pest control and environmental safety. Forum Nutr. 2003, 56, 317-318.

223. Chen, D.M.; Yang, H.J.; Huang, J.G.; Yuan, L. Lysobacter enzymogenes LE16 autolysates have potential as biocontrol agentsLysobacter sp. autolysates as biofungicide. J. Appl. Microbiol. 2020, 129, 1684-1692. [CrossRef]

224. Rasche, F.; Velvis, H.; Zachow, C.; Berg, G.; van Elsas, J.D.; Sessitsch, A. Impact of transgenic potatoes expressing anti-bacterial agents on bacterial endophytes is comparable with the effects of plant genotype, soil type and pathogen infection. J. Appl. Ecol. 2006, 43, 555-566. [CrossRef]

225. Salm, H.; Kim, W.S.; Geider, K.; Schneider, B. Control of fire blight with a lysozyme from the Erwinia amylovora phage EA1H. Acta Hortic. 2006, 371-374. [CrossRef]

226. Cabrefiga, J.; Montesinos, E. Lysozyme enhances the bactericidal effect of BP100 peptide against Erwinia amylovora, the causal agent of fire blight of rosaceous plants. BMC Microbiol. 2017, 17, 39. [CrossRef] [PubMed]

227. Nakatsuji, T.; Gallo, R.L. Antimicrobial peptides: Old molecules with new ideas. J. Investig. Dermatol. 2012, 132, 887-895. [CrossRef]

228. Hancock, R.E.; Scott, M.G. The role of antimicrobial peptides in animal defenses. Proc. Natl. Acad. Sci. USA 2000, 97, 8856-8861. [CrossRef]

229. Scott, M.G.; Hancock, R.E. Cationic antimicrobial peptides and their multifunctional role in the immune system. Crit. Rev. Immunol. 2000, 20, 407-431. [CrossRef]

230. Yan, H.; Hancock, R.E. Synergistic interactions between mammalian antimicrobial defense peptides. Antimicrob. Agents Chemother. 2001, 45, 1558-1560. [CrossRef] [PubMed]

231. Blumenthal, I.; Davis, L.R.; Berman, C.M.; Griswold, K.E. Nonclassical antagonism between human lysozyme and AMPs against Pseudomonas aeruginosa. FEBS Open Bio 2021, 11, 705-713. [CrossRef] [PubMed] 
232. Patrzykat, A.; Zhang, L.; Mendoza, V.; Iwama, G.K.; Hancock, R.E. Synergy of histone-derived peptides of coho salmon with lysozyme and flounder pleurocidin. Antimicrob. Agents Chemother. 2001, 45, 1337-1342. [CrossRef] [PubMed]

233. Aguilar-Pérez, C.; Gracia, B.; Rodrigues, L.; Vitoria, A.; Cebrián, R.; Deboosère, N.; Song, O.-R.; Brodin, P.; Maqueda, M.; Aínsa, J.A. Synergy between Circular Bacteriocin AS-48 and Ethambutol against Mycobacterium tuberculosis. Antimicrob. Agents Chemother. 2018, 62, e00359-18. [CrossRef]

234. Ellison, R.T.; Giehl, T.J. Killing of gram-negative bacteria by lactoferrin and lysozyme. J. Clin. Investig. 1991, 88, 1080-1091. [CrossRef]

235. André, G.O.; Politano, W.R.; Mirza, S.; Converso, T.R.; Ferraz, L.F.C.; Leite, L.C.C.; Darrieux, M. Combined effects of lactoferrin and lysozyme on Streptococcus pneumoniae killing. Microb. Pathog. 2015, 89, 7-17. [CrossRef]

236. Singh, P.K.; Tack, B.F.; McCray, P.B.; Welsh, M.J. Synergistic and additive killing by antimicrobial factors found in human airway surface liquid. Am. J. Physiol. Lung Cell. Mol. Physiol. 2000, 279, L799-L805. [CrossRef] [PubMed]

237. Boland, J.S.; Davidson, P.M.; Bruce, B.; Weiss, J. Cations reduce antimicrobial efficacy of lysozyme-chelator combinations. J. Food Prot. 2004, 67, 285-294. [CrossRef]

238. Boland, J.S.; Davidson, P.M.; Weiss, J. Enhanced inhibition of Escherichia coli O157:H7 by lysozyme and chelators. J. Food Prot. 2003, 66, 1783-1789. [CrossRef]

239. Branen, J.K.; Davidson, P. Enhancement of nisin, lysozyme, and monolaurin antimicrobial activities by ethylenediaminetetraacetic acid and lactoferrin. Int. J. Food Microbiol. 2004, 90, 63-74. [CrossRef]

240. Penta, J.; Jannu, K.K.; Musthyala, R. Antimicrobial studies of selected antibiotics and their combination with enzymes. Int. J. Pharm. Pharm. Sci. 2010, 2, 43-44.

241. Perez, H.A.; Bustos, A.Y.; Taranto, M.P.; Frías, M.D.L.A.; Ledesma, A.E. Effects of Lysozyme on the Activity of Ionic of Fluoroquinolone Species. Molecules 2018, 23, 741. [CrossRef] [PubMed]

242. Das, I.; Halder, M. Counterpointing Scenarios on the Fate of Different Prototropic Forms of Norfloxacin Housed in the Pocket of Lysozyme: The Nonelectrostatic Interactions in the Protein Interior Are in the Controlling Role on the Prototropic Equilibria of the Guest. ACS Omega 2017, 2, 5504-5517. [CrossRef] [PubMed]

243. Ali, M.S.; Waseem, M.; Subbarao, N.; Al-Lohedan, H.A. Dynamic interaction between lysozyme and ceftazidime: Experimental and molecular simulation approaches. J. Mol. Liq. 2021, 328, 115412. [CrossRef]

244. Bhavsar, T.; Liu, M.; Liu, X.; Cantor, J. Aerosolized recombinant human lysozyme enhances the bactericidal effect of tobramycin in a hamster model of Pseudomonas aeruginosa-induced pneumonia. Exp. Lung Res. 2011, 37, 536-541. [CrossRef] [PubMed]

245. Torrens, G.; Pérez-Gallego, M.; Moya, B.; Munar-Bestard, M.; Zamorano, L.; Cabot, G.; Blázquez, J.; Ayala, J.A.; Oliver, A.; Juan, C. Targeting the permeability barrier and peptidoglycan recycling pathways to disarm Pseudomonas aeruginosa against the innate immune system. PLoS ONE 2017, 12, e0181932. [CrossRef]

246. Torrens, G.; Barceló, I.M.; Pérez-Gallego, M.; Escobar-Salom, M.; Tur-Gracia, S.; Munar-Bestard, M.; Del González-Nicolau, M.M.; Cabrera-Venegas, Y.J.; Rigo-Rumbos, E.N.; Cabot, G.; et al. Profiling the susceptibility of Pseudomonas aeruginosa strains from acute and chronic infections to cell-wall-targeting immune proteins. Sci. Rep. 2019, 9, 3575. [CrossRef]

247. Vouillamoz, J.; Entenza, J.M.; Giddey, M.; Fischetti, V.A.; Moreillon, P.; Resch, G. Bactericidal synergism between daptomycin and the phage lysin Cpl-1 in a mouse model of pneumococcal bacteraemia. Int. J. Antimicrob. Agents 2013, 42, 416-421. [CrossRef]

248. Zhang, X.; Jiang, A.; Yu, H.; Xiong, Y.; Zhou, G.; Qin, M.; Dou, J.; Wang, J. Human Lysozyme Synergistically Enhances Bactericidal Dynamics and Lowers the Resistant Mutant Prevention Concentration for Metronidazole to Helicobacter pylori by Increasing Cell Permeability. Molecules 2016, 21, 1435. [CrossRef] [PubMed]

249. Zharkova, M.S.; Orlov, D.S.; Golubeva, O.Y.; Chakchir, O.B.; Eliseev, I.E.; Grinchuk, T.M.; Shamova, O.V. Application of Antimicrobial Peptides of the Innate Immune System in Combination With Conventional Antibiotics-A Novel Way to Combat Antibiotic Resistance? Front. Cell. Infect. Microbiol. 2019, 9, 128. [CrossRef] [PubMed]

250. Lv, H.; Zhang, Y.; Chen, P.; Xue, J.; Jia, X.; Chen, J. Enhanced Synergistic Antibacterial Activity through a Smart Platform Based on UiO-66 Combined with Photodynamic Therapy and Chemotherapy. Langmuir 2020, 36, 4025-4032. [CrossRef] [PubMed]

251. Kawai, Y.; Mickiewicz, K.; Errington, J. Lysozyme Counteracts $\beta$-Lactam Antibiotics by Promoting the Emergence of L-Form Bacteria. Cell 2018, 172, 1038-1049.e10. [CrossRef] [PubMed]

252. Burke, T.P. The Unexpected Effects of the Combination of Antibiotics and Immunity. Cell 2018, 172, 891-893. [CrossRef]

253. Mateus, L.; Costa, L.; Silva, Y.J.; Pereira, C.; Almeida, A. Effect of lysozyme addition on the activity of phages against Vibrio parahaemolyticus. Aquaculture 2014, 432, 125-129. [CrossRef]

254. Vahdati, M.; Tohidi Moghadam, T. Synthesis and Characterization of Selenium Nanoparticles-Lysozyme Nanohybrid System with Synergistic Antibacterial Properties. Sci. Rep. 2020, 10, 510. [CrossRef]

255. Hariri, B.M.; McMahon, D.B.; Chen, B.; Adappa, N.D.; Palmer, J.N.; Kennedy, D.W.; Lee, R.J. Plant flavones enhance antimicrobial activity of respiratory epithelial cell secretions against Pseudomonas aeruginosa. PLoS ONE 2017, 12, e0185203. [CrossRef] [PubMed]

256. Zdybicka-Barabas, A.; Staczek, S.; Mak, P.; Skrzypiec, K.; Mendyk, E.; Cytryńska, M. Synergistic action of Galleria mellonella apolipophorin III and lysozyme against Gram-negative bacteria. Biochim. Biophys. Acta 2013, 1828, 1449-1456. [CrossRef]

257. Homaei, A.A.; Sariri, R.; Vianello, F.; Stevanato, R. Enzyme immobilization: An update. J. Chem. Biol. 2013, 6, 185-205. [CrossRef]

258. Sheldon, R.A.; Schoevaart, R.; van Langen, L.M. Cross-linked enzyme aggregates (CLEAs): A novel and versatile method for enzyme immobilization (a review). Biocatal. Biotransform. 2005, 23, 141-147. [CrossRef] 
259. Alves, C.R.; Pimenta, M.G.R.; Vieira, R.H.; Furtado, R.F.; Guedes, M.I.F.; Silva, R.C.; Assis, O.B. Practical use of immobilized lysozyme for the remediation process of Escherichia coli in aqueous solution. Electron. J. Biotechnol. 2007, 10, 160-165. [CrossRef]

260. Wang, Q.; Fan, X.; Hu, Y.; Yuan, J.; Cui, L.; Wang, P. Antibacterial functionalization of wool fabric via immobilizing lysozymes. Bioprocess Biosyst. Eng. 2009, 32, 633-639. [CrossRef]

261. Yang, W.; Zhang, N.; Wang, Q.; Wang, P.; Yu, Y. Development of an eco-friendly antibacterial textile: Lysozyme immobilization on wool fabric. Bioprocess Biosyst. Eng. 2020, 43, 1639-1648. [CrossRef] [PubMed]

262. Edwards, J.V.; Prevost, N.; Condon, B.; Sethumadhavan, K.; Ullah, J.; Bopp, A. Immobilization of Lysozyme on Cotton Fabrics: Synthesis, Characterization, and Activity. AATCC Rev. 2011, 11, 73-79.

263. Dickerson, M.B.; Knight, C.L.; Gupta, M.K.; Luckarift, H.R.; Drummy, L.F.; Jespersen, M.L.; Johnson, G.R.; Naik, R.R. Hybrid fibers containing protein-templated nanomaterials and biologically active components as antibacterial materials. Mater. Sci. Eng. C 2011, 31, 1748-1758. [CrossRef]

264. Liu, W.; Cai, M.; He, Y.; Wang, S.; Zheng, J.; Xu, X. Development of antibacterial polyacrylonitrile membrane modified with a covalently immobilized lysozyme. RSC Adv. 2015, 5, 84432-84438. [CrossRef]

265. Fang, J.; Liu, G.; Chen, C.; Lin, C.; Zhang, B.; Jin, H.; Chen, Y.; Lu, J.; Zhu, L. Intrinsically antibacterial thin film composite membranes with supramolecularly assembled lysozyme nanofilm as selective layer for molecular separation. Sep. Pur. Technol. 2021, 254, 117585. [CrossRef]

266. Kim, M.; Park, J.-M.; Yoon, J.; Min, J.; Kim, Y.-H. Synthesis and characterization of CLEA-lysozyme immobilized PS/PSMA nanofiber. J. Nanosci. Nanotechnol. 2011, 11, 7894-7900. [CrossRef]

267. Teixeira-Dias, B.; Del Valle, L.J.; Aradilla, D.; Estrany, F.; Alemán, C. A Conducting Polymer/Protein Composite with Bactericidal and Electroactive Properties. Macromol. Mater. Eng. 2012, 297, 427-436. [CrossRef]

268. Li, W.; Li, X.; Wang, Q.; Pan, Y.; Wang, T.; Wang, H.; Song, R.; Deng, H. Antibacterial activity of nanofibrous mats coated with lysozyme-layered silicate composites via electrospraying. Carbohydr. Polym. 2014, 99, 218-225. [CrossRef]

269. Dekina, S.; Romanovska, I.; Ovsepyan, A.; Tkach, V.; Muratov, E. Gelatin/carboxymethyl cellulose mucoadhesive films with lysozyme: Development and characterization. Carbohydr. Polym. 2016, 147, 208-215. [CrossRef] [PubMed]

270. Jin, Z.; Harvey, A.M.; Mailloux, S.; Halámek, J.; Bocharova, V.; Twiss, M.R.; Katz, E. Electrochemically stimulated release of lysozyme from an alginate matrix cross-linked with iron cations. J. Mater. Chem. 2012, 22, 19523. [CrossRef]

271. Park, J.-M.; Kim, M.; Park, H.-S.; Jang, A.; Min, J.; Kim, Y.-H. Immobilization of lysozyme-CLEA onto electrospun chitosan nanofiber for effective antibacterial applications. Int. J. Biol. Macromol. 2013, 54, 37-43. [CrossRef] [PubMed]

272. Wu, T.; Huang, J.; Jiang, Y.; Hu, Y.; Ye, X.; Liu, D.; Chen, J. Formation of hydrogels based on chitosan/alginate for the delivery of lysozyme and their antibacterial activity. Food Chem. 2018, 240, 361-369. [CrossRef] [PubMed]

273. Martins, A.M.; Pereira, R.C.; Leonor, I.B.; Azevedo, H.S.; Reis, R.L. Chitosan scaffolds incorporating lysozyme into CaP coatings produced by a biomimetic route: A novel concept for tissue engineering combining a self-regulated degradation system with in situ pore formation. Acta Biomater. 2009, 5, 3328-3336. [CrossRef]

274. Bueno, V.B.; Petri, D.F.S. Xanthan hydrogel films: Molecular conformation, charge density and protein carriers. Carbohydr. Polym. 2014, 101, 897-904. [CrossRef]

275. Levashov, P.A.; Matolygina, D.A.; Ovchinnikova, E.D.; Adamova, I.Y.; Gasanova, D.A.; Smirnov, S.A.; Nelyub, V.A.; Belogurova, N.G.; Tishkov, V.I.; Eremeev, N.L.; et al. The bacteriolytic activity of native and covalently immobilized lysozyme against Gram-positive and Gram-negative bacteria is differentially affected by charged amino acids and glycine. FEBS Open Bio 2019, 9, 510-518. [CrossRef]

276. Yang, M.; Wang, Y.; Tao, G.; Cai, R.; Wang, P.; Liu, L.; Ai, L.; Zuo, H.; Zhao, P.; Umar, A.; et al. Fabrication of Sericin/Agrose Gel Loaded Lysozyme and Its Potential in Wound Dressing Application. Nanomaterials 2018, 8, 235. [CrossRef] [PubMed]

277. Matouskova, P.; Marova, I.; Bokrova, J.; Benesova, P. Effect of Encapsulation on Antimicrobial Activity of Herbal Extracts with Lysozyme. Food Technol. Biotechnol. 2016, 54, 304-316. [CrossRef] [PubMed]

278. Kandemir, N.; Yemenicioğlu, A.; Mecitoğlu, Ç.; Elmac1, Z.S.; Baysal, T. Production of Antimicrobial Films by Incorporation of Partially Purified Lysozyme into Biodegradable Films of Crude Exopolysaccharides Obtained from Aureobasidium pullulans Fermentation. Food Technol. Biotechnol. 2005, 43, 343-350.

279. Duan, L.; Wang, Y.; Zhang, Y.; Liu, J. Graphene immobilized enzyme/polyethersulfone mixed matrix membrane: Enhanced antibacterial, permeable and mechanical properties. Appl. Surf. Sci. 2015, 355, 436-445. [CrossRef]

280. Hao, X.; Chen, S.; Zhu, H.; Wang, L.; Zhang, Y.; Yin, Y. The Synergy of Graphene Oxide and Polydopamine Assisted Immobilization of Lysozyme to Improve Antibacterial Properties. ChemistrySelect 2017, 2, 2174-2182. [CrossRef]

281. Schoonen, L.; Maassen, S.; Nolte, R.J.M.; van Hest, J.C.M. Stabilization of a Virus-Like Particle and Its Application as a Nanoreactor at Physiological Conditions. Biomacromolecules 2017, 18, 3492-3497. [CrossRef]

282. Zhou, D.; Yang, T.; Qian, W.; Xing, M.; Luo, G. Study of the mechanism of environmentally friendly translucent balsa-modified lysozyme dressing for facilitating wound healing. Int. J. Nanomed. 2018, 13, 4171-4187. [CrossRef] [PubMed]

283. Zhou, D.; Yang, T.; Xing, M.; Luo, G. Preparation of a balsa-lysozyme eco-friendly dressing and its effect on wound healing. RSC Adv. 2018, 8, 13493-13502. [CrossRef]

284. Shi, P.; Luo, S.; Voit, B.; Appelhans, D.; Zan, X. A facile and efficient strategy to encapsulate the model basic protein lysozyme into porous $\mathrm{CaCO}_{3}$. J. Mater. Chem. B 2018, 6, 4205-4215. [CrossRef] [PubMed] 
285. Wang, Z.; Yu, H.; Ma, K.; Chen, Y.; Zhang, X.; Wang, T.; Li, S.; Zhu, X.; Wang, X. Flower-like Surface of Three-Metal-Component Layered Double Hydroxide Composites for Improved Antibacterial Activity of Lysozyme. Bioconjug. Chem. 2018, 29, 2090-2099. [CrossRef] [PubMed]

286. de Oliveira, L.F.; de Almeida Gonçalves, K.; Boreli, F.H.; Kobarg, J.; Cardoso, M.B. Mechanism of interaction between colloids and bacteria as evidenced by tailored silica-lysozyme composites. J. Mater. Chem. 2012, 22, 22851. [CrossRef]

287. Brunaugh, A.D.; Seo, H.; Warnken, Z.; Ding, L.; Seo, S.H.; Smyth, H.D.C. Development and evaluation of inhalable composite niclosamide-lysozyme particles: A broad-spectrum, patient-adaptable treatment for coronavirus infections and sequalae. PLoS ONE 2021, 16, e0246803. [CrossRef] [PubMed]

288. Chen, S.-L.; Weng, Y.-M.; Huang, J.-J.; Lin, K.-J. Physicochemical characteristics and bacteriostatic ability of modified lysozyme from lactic acid-induced gelled egg white powder. J. Food Process. Preserv. 2012, 36, 232-241. [CrossRef]

289. Cavalieri, F.; Micheli, L.; Kaliappan, S.; Teo, B.M.; Zhou, M.; Palleschi, G.; Ashokkumar, M. Antimicrobial and biosensing ultrasound-responsive lysozyme-shelled microbubbles. ACS Appl. Mater. Interfaces 2013, 5, 464-471. [CrossRef]

290. Mahalingam, S.; Xu, Z.; Edirisinghe, M. Antibacterial Activity and Biosensing of PVA-Lysozyme Microbubbles Formed by Pressurized Gyration. Langmuir 2015, 31, 9771-9780. [CrossRef]

291. Sarkar, S.; Gulati, K.; Mishra, A.; Poluri, K.M. Protein nanocomposites: Special inferences to lysozyme based nanomaterials. Int. J. Biol. Macromol. 2020, 151, 467-482. [CrossRef] [PubMed]

292. Abouhmad, A.; Dishisha, T.; Amin, M.A.; Hatti-Kaul, R. Immobilization to Positively Charged Cellulose Nanocrystals Enhances the Antibacterial Activity and Stability of Hen Egg White and T4 Lysozyme. Biomacromolecules 2017, 18, 1600-1608. [CrossRef] [PubMed]

293. Wang, P.; Zhang, C.; Zou, Y.; Li, Y.; Zhang, H. Immobilization of lysozyme on layer-by-layer self-assembled electrospun films: Characterization and antibacterial activity in milk. Food Hydrocoll. 2021, 113, 106468. [CrossRef]

294. Huang, W.; Li, X.; Xue, Y.; Huang, R.; Deng, H.; Ma, Z. Antibacterial multilayer films fabricated by LBL immobilizing lysozyme and HTCC on nanofibrous mats. Int. J. Biol. Macromol. 2013, 53, 26-31. [CrossRef]

295. Zhang, H.; Feng, M.; Chen, S.; Shi, W.; Wang, X. Incorporation of lysozyme into cellulose nanocrystals stabilized $\beta$-chitosan nanoparticles with enhanced antibacterial activity. Carbohydr. Polym. 2020, 236, 115974. [CrossRef] [PubMed]

296. Uddin, K.M.A.; Orelma, H.; Mohammadi, P.; Borghei, M.; Laine, J.; Linder, M.; Rojas, O.J. Retention of lysozyme activity by physical immobilization in nanocellulose aerogels and antibacterial effects. Cellulose 2017, 24, 2837-2848. [CrossRef]

297. Jiang, S.; Qin, Y.; Yang, J.; Li, M.; Xiong, L.; Sun, Q. Enhanced antibacterial activity of lysozyme immobilized on chitin nanowhiskers. Food Chem. 2017, 221, 1507-1513. [CrossRef] [PubMed]

298. Sun, X.; Jia, P.; Zhe, T.; Bu, T.; Liu, Y.; Wang, Q.; Wang, L. Construction and multifunctionalization of chitosan-based three-phase nano-delivery system. Food Hydrocoll. 2019, 96, 402-411. [CrossRef]

299. Piras, A.M.; Maisetta, G.; Sandreschi, S.; Esin, S.; Gazzarri, M.; Batoni, G.; Chiellini, F. Preparation, physical-chemical and biological characterization of chitosan nanoparticles loaded with lysozyme. Int. J. Biol. Macromol. 2014, 67, 124-131. [CrossRef] [PubMed]

300. Liu, Y.; Sun, Y.; Xu, Y.; Feng, H.; Fu, S.; Tang, J.; Liu, W.; Sun, D.; Jiang, H.; Xu, S. Preparation and evaluation of lysozyme-loaded nanoparticles coated with poly- $\gamma$-glutamic acid and chitosan. Int. J. Biol. Macromol. 2013, 59, 201-207. [CrossRef] [PubMed]

301. Li, X.; Xu, J.; Wang, D.; Sha, Y.; Chen, W.; Zhou, D.; Wang, X.; Sun, Q.; Xue, G.; Li, L. Low-temperature processing of polymer nanoparticles for bioactive composites. J. Polym. Sci. Part B Polym. Phys. 2016, 54, 2514-2520. [CrossRef]

302. Yu, Q.; Ista, L.K.; López, G.P. Nanopatterned antimicrobial enzymatic surfaces combining biocidal and fouling release properties. Nanoscale 2014, 6, 4750-4757. [CrossRef] [PubMed]

303. Wang, Y.; Xue, Y.; Bi, Q.; Qin, D.; Du, Q.; Jin, P. Enhanced antibacterial activity of eugenol-entrapped casein nanoparticles amended with lysozyme against gram-positive pathogens. Food Chem. 2021, 360, 130036. [CrossRef]

304. Li, J.; Liu, X.; Zhou, Z.; Tan, L.; Wang, X.; Zheng, Y.; Han, Y.; Chen, D.-F.; Yeung, K.W.K.; Cui, Z.; et al. Lysozyme-Assisted Photothermal Eradication of Methicillin-Resistant Staphylococcus aureus Infection and Accelerated Tissue Repair with Natural Melanosome Nanostructures. ACS Nano 2019, 13, 11153-11167. [CrossRef] [PubMed]

305. Zheng, K.; Lu, M.; Liu, Y.; Chen, Q.; Taccardi, N.; Hüser, N.; Boccaccini, A.R. Monodispersed lysozyme-functionalized bioactive glass nanoparticles with antibacterial and anticancer activities. Biomed. Mater. 2016, 11, 35012. [CrossRef]

306. Noor, M.M.; Goswami, J.; Davis, V.A. Comparison of Attachment and Antibacterial Activity of Covalent and Noncovalent Lysozyme-Functionalized Single-Walled Carbon Nanotubes. ACS Omega 2020, 5, 2254-2259. [CrossRef]

307. Horn, D.W.; Tracy, K.; Easley, C.J.; Davis, V.A. Lysozyme Dispersed Single-Walled Carbon Nanotubes: Interaction and Activity. J. Phys. Chem. C 2012, 116, 10341-10348. [CrossRef]

308. Nepal, D.; Minus, M.L.; Kumar, S. Lysozyme coated DNA and DNA/SWNT fibers by solution spinning. Macromol. Biosci. 2011, 11, 875-881. [CrossRef]

309. Perevedentseva, E.; Cheng, C.-Y.; Chung, P.-H.; Tu, J.-S.; Hsieh, Y.-H.; Cheng, C.-L. The interaction of the protein lysozyme with bacteria E. coli observed using nanodiamond labelling. Nanotechnology 2007, 18, 315102. [CrossRef]

310. Li, L.-L.; Wang, H. Enzyme-coated mesoporous silica nanoparticles as efficient antibacterial agents in vivo. Adv. Healthc. Mater. 2013, 2, 1351-1360. [CrossRef] [PubMed]

311. Wei, T.; Yu, Q.; Zhan, W.; Chen, H. A Smart Antibacterial Surface for the On-Demand Killing and Releasing of Bacteria. Adv. Healthc. Mater. 2016, 5, 449-456. [CrossRef] [PubMed] 
312. Zhao, Q.; Liu, C.; Liu, J.; Zhang, Y. Development of a novel polyethersulfone ultrafiltration membrane with antibacterial activity and high flux containing halloysite nanotubes loaded with lysozyme. RSC Adv. 2015, 5, 38646-38653. [CrossRef]

313. Golubeva, O.Y.; Shamova, O.V.; Yakovlev, A.V.; Zharkova, M.S. Synthesis and study of the biologically active lysozyme-silver nanoparticles-montmorillonite K10 complexes. Glass Phys. Chem. 2016, 42, 87-94. [CrossRef]

314. Golubeva, O.Y.; Brazovskaya, E.Y.; Shamova, O.V. Biological activity and sorption ability of synthetic montmorillonite modified by silver/lysozyme nanoparticles. Appl. Clay Sci. 2018, 163, 56-62. [CrossRef]

315. Zhan, Y.; Zeng, W.; Jiang, G.; Wang, Q.; Shi, X.; Zhou, Z.; Deng, H.; Du, Y. Construction of lysozyme exfoliated rectorite-based electrospun nanofibrous membranes for bacterial inhibition. J. Appl. Polym. Sci. 2015, 132. [CrossRef]

316. Ma, D.; Xie, C.; Wang, T.; Mei, L.; Zhang, X.; Guo, Z.; Yin, W. Liquid-Phase Exfoliation and Functionalization of MoS 2 Nanosheets for Effective Antibacterial Application. Chembiochem 2020, 21, 2373-2380. [CrossRef]

317. Remanan, S.; Samantaray, P.K.; Bose, S.; Das, N.C. Phase transited lysozyme particles and $\mathrm{MoS}_{2}$ nanosheets modified elastomerlike antibacterial and antifouling microfiltration membrane derived from poly(ethylene-co-methyl acrylate)/poly(vinylidene fluoride) (EMA/PVDF) blend for water purification application. Microporous Mesoporous Mater. 2021, 316, 110945. [CrossRef]

318. Tripathy, N.; Ahmad, R.; Bang, S.H.; Min, J.; Hahn, Y.-B. Tailored lysozyme-ZnO nanoparticle conjugates as nanoantibiotics. Chem. Commun. 2014, 50, 9298-9301. [CrossRef] [PubMed]

319. Wang, Y.; Zhang, D. Hetero-nanostructured film of titania nanosheets and lysozyme: Fabrication and synergistic antibacterial properties. Surf. Coat. Technol. 2012, 210, 71-77. [CrossRef]

320. Yang, Q.-Z.; Chang, Y.-Y.; Zhao, H.-Z. Preparation and antibacterial activity of lysozyme and layered double hydroxide nanocomposites. Water Res. 2013, 47, 6712-6718. [CrossRef]

321. Kalita, S.; Kandimalla, R.; Bhowal, A.C.; Kotoky, J.; Kundu, S. Functionalization of $\beta$-Lactam antibiotic on lysozyme capped gold nanoclusters retrogress MRSA and its persisters following awakening. Sci. Rep. 2018, 8, 5778. [CrossRef]

322. Kumar, U.; Ranjan, A.K.; Sharan, C.; Hardikar, A.A.; Pundle, A.; Poddar, P. Green Approach Towards Size Controlled Synthesis of Biocompatible Antibacterial Metal Nanoparticles in Aqueous Phase Using Lysozyme. Curr. Nanosci. 2012, 8, 130-140. [CrossRef]

323. Su, Y.; Li, C. Stable multilayer thin films composed of gold nanoparticles and lysozyme. Appl. Surf. Sci. 2008, 254, 2003-2008. [CrossRef]

324. Chen, W.-Y.; Lin, J.-Y.; Chen, W.-J.; Luo, L.; Wei-Guang Diau, E.; Chen, Y.-C. Functional gold nanoclusters as antimicrobial agents for antibiotic-resistant bacteria. Nanomedicine 2010, 5, 755-764. [CrossRef] [PubMed]

325. Qu, Y.; Wei, T.; Zhao, J.; Jiang, S.; Yang, P.; Yu, Q.; Chen, H. Regenerable smart antibacterial surfaces: Full removal of killed bacteria via a sequential degradable layer. J. Mater. Chem. B 2018, 6, 3946-3955. [CrossRef] [PubMed]

326. Eby, D.M.; Schaeublin, N.M.; Farrington, K.E.; Hussain, S.M.; Johnson, G.R. Lysozyme catalyzes the formation of antimicrobial silver nanoparticles. ACS Nano 2009, 3, 984-994. [CrossRef] [PubMed]

327. Coll Ferrer, M.C.; Dastgheyb, S.; Hickok, N.J.; Eckmann, D.M.; Composto, R.J. Designing nanogel carriers for antibacterial applications. Acta Biomater. 2014, 10, 2105-2111. [CrossRef]

328. Pellegrini, A.; Thomas, U.; Ibrahim, H.R. A Bactericidal Domain of Lysozyme with Helix-Loop-Helix Structure Present a Strong Antimicrobial Activity. In Proceedings of the Peptides 2002 27th European Peptide Symposium, Sorrento, Italy, 31 August-6 September 2002; Benedetti, E., Pedone, C., Eds.; pp. 582-583.

329. Pellegrini, A. Antimicrobial peptides from food proteins. Curr. Pharm. Des. 2003, 9, 1225-1238. [CrossRef]

330. Lee-Huang, S.; Huang, P.L.; Huang, P. Anti-HIV and Anti-Tumor Peptides and Fragments of Lysozyme. Patent No. WO2002004011, 17 January 2002.

331. Ibrahim, H.R.; Inazaki, D.; Abdou, A.; Aoki, T.; Kim, M. Processing of lysozyme at distinct loops by pepsin: A novel action for generating multiple antimicrobial peptide motifs in the newborn stomach. Biochim. Biophys. Acta 2005, 1726, 102-114. [CrossRef]

332. Carrillo, W.; Lucio, A.; Gaibor, J.; Morales, D.; Vásquez, G. Isolation of Antibacterial Hydrolysates from Hen Egg White Lysozyme and Identification of Antibacterial Peptides. J. Med. Food 2018, 21, 808-818. [CrossRef] [PubMed]

333. Pellegrini, A.; Thomas, U.; Wild, P.; Schraner, E.; von Fellenberg, R. Effect of lysozyme or modified lysozyme fragments on DNA and RNA synthesis and membrane permeability of Escherichia coli. Microbiol. Res. 2000, 155, 69-77. [CrossRef]

334. Li, Q.; Zhou, Y.; Dong, K.; Guo, X. Potential therapeutic efficacy of a bactericidal-immunomodulatory fusion peptide against methicillin-resistant Staphylococcus aureus skin infection. Appl. Microbiol. Biotechnol. 2010, 86, 305-309. [CrossRef] [PubMed]

335. Lukacik, P.; Barnard, T.J.; Keller, P.W.; Chaturvedi, K.S.; Seddiki, N.; Fairman, J.W.; Noinaj, N.; Kirby, T.L.; Henderson, J.P.; Steven, A.C.; et al. Structural engineering of a phage lysin that targets gram-negative pathogens. Proc. Natl. Acad. Sci. USA 2012, 109, 9857-9862. [CrossRef]

336. Appaiah, C.B.; Saravanan, R.S.; Sriram, B. Chimeric Antibacterial Polypeptides Constructed from Muralytic Domains and Membrane-Traversing Domains. Patent No. WO2012140676, 18 October 2012.

337. Zhu, D.; Cai, G.; Li, X.; Lu, J.; Zhang, L. Enhancing the antimicrobial activity of Sus scrofa lysozyme by N-terminal fusion of a sextuple unique homologous peptide. J. Biotechnol. 2017, 243, 61-68. [CrossRef]

338. Saito, H.; Sakakibara, Y.; Sakata, A.; Kurashige, R.; Murakami, D.; Kageshima, H.; Saito, A.; Miyazaki, Y. Antibacterial activity of lysozyme-chitosan oligosaccharide conjugates (LYZOX) against Pseudomonas aeruginosa, Acinetobacter baumannii and Methicillinresistant Staphylococcus aureus. PLoS ONE 2019, 14, e217504. [CrossRef]

339. Tan, M.; Wang, H.; Wang, Y.; Chen, G.; Yuan, L.; Chen, H. Recyclable antibacterial material: Silicon grafted with 3,6-O-sulfated chitosan and specifically bound by lysozyme. J. Mater. Chem. B 2014, 2, 569-576. [CrossRef] 
340. Kim, S.; Fan, J.; Lee, C.-S.; Lee, M. Dual Functional Lysozyme-Chitosan Conjugate for Tunable Degradation and Antibacterial Activity. ACS Appl. Bio Mater. 2020, 3, 2334-2343. [CrossRef]

341. Filatova, L.Y.; Balabushevich, N.G.; Klyachko, N.L. A physicochemical, structural, microbiological and kinetic study of hen egg white lysozyme in complexes with alginate and chitosan. Biocatal. Biotransform. 2021, 1-14. [CrossRef]

342. Alahdad, Z.; Ramezani, R.; Aminlari, M.; Majzoobi, M. Preparation and properties of dextran sulfate-lysozyme conjugate. J. Agric. Food Chem. 2009, 57, 6449-6454. [CrossRef] [PubMed]

343. Hashemi, M.M.; Aminlari, M.; Moosavinasab, M. Preparation of and studies on the functional properties and bactericidal activity of the lysozyme-xanthan gum conjugate. LWT-Food Sci. Technol. 2014, 57, 594-602. [CrossRef]

344. Tziveleka, L.-A.; Pippa, N.; Georgantea, P.; Ioannou, E.; Demetzos, C.; Roussis, V. Marine sulfated polysaccharides as versatile polyelectrolytes for the development of drug delivery nanoplatforms: Complexation of ulvan with lysozyme. Int. J. Biol. Macromol. 2018, 118, 69-75. [CrossRef] [PubMed]

345. Evran, S.; Yasa, I.; Telefoncu, A. Modification of lysozyme with oleoyl chloride for broadening the antimicrobial specificity. Prep. Biochem. Biotechnol. 2010, 40, 316-325. [CrossRef]

346. Clementi, E.A.; Wilhelm, K.R.; Schleucher, J.; Morozova-Roche, L.A.; Hakansson, A.P. A complex of equine lysozyme and oleic acid with bactericidal activity against Streptococcus pneumoniae. PLoS ONE 2013, 8, e80649. [CrossRef]

347. Nguyen, S.N.; Bobst, C.E.; Kaltashov, I.A. Compositions and Methods for Delivering Agents to the Central Nervous System. Patent No. WO2014152678, 25 September 2014.

348. Nodake, Y.; Iwasaki, K.; Yamasaki, N. Interactions of a lysozyme-monomethoxypolyethylene glycol conjugate with lipopolysaccharides and lipid bilayers and effects of conjugate on Gram-negative bacteria. Biosci. Biotechnol. Biochem. 2002, 66, 1848-1852. [CrossRef] [PubMed]

349. Steiert, E.; Radi, L.; Fach, M.; Wich, P.R. Protein-Based Nanoparticles for the Delivery of Enzymes with Antibacterial Activity. Macromol. Rapid Commun. 2018, 39, e1800186. [CrossRef] [PubMed]

350. Diken Gür, S.; Bakhshpour, M.; Bereli, N.; Denizli, A. Antibacterial effect against both Gram-positive and Gram-negative bacteria via lysozyme imprinted cryogel membranes. J. Biomater. Sci. Polym. Ed. 2021, 32, 1024-1039. [CrossRef] [PubMed]

351. Novaković, I.; Anđelković, U.; Zlatović, M.; Gašić, M.J.; Sladić, D. Bioconjugate of lysozyme and the antibacterial marine sesquiterpene quinone avarone and its derivatives. Bioconjug. Chem. 2012, 23, 57-65. [CrossRef] [PubMed]

352. Mansour, A.M. Antifungal activity, DNA and lysozyme binding affinity of $\mathrm{Pd}(\mathrm{II})$ and $\mathrm{Pt}(\mathrm{II})$ complexes bearing $\mathrm{N}$, Npyridylbenzimidazole ligand. J. Coord. Chem. 2018, 71, 3381-3391. [CrossRef]

353. Mansour, A.M.; Shehab, O.R. Pyridylbenzimidazole-Based Gold(III) Complexes: Lysozyme Metalation, DNA Binding Studies, and Biological Activity. Eur. J. Inorg. Chem. 2019, 2019, 2830-2838. [CrossRef]

354. Singh, G.; Kaur, M.; Kaur, H.; Kang, T.S. Synthesis and complexation of a new caffeine based surface active ionic liquid with lysozyme in aqueous medium: Physicochemical, computational and antimicrobial studies. J. Mol. Liq. 2021, $325,115156$. [CrossRef]

355. Hoq, M.I.; Mitsuno, K.; Tsujino, Y.; Aoki, T.; Ibrahim, H.R. Triclosan-lysozyme complex as novel antimicrobial macromolecule: A new potential of lysozyme as phenolic drug-targeting molecule. Int. J. Biol. Macromol. 2008, 42, 468-477. [CrossRef] [PubMed]

356. Imranul Hoq, M.; Aoki, T.; Ibrahim, H.R. Triclosan-lysozyme complex: A promising antimicrobial macromolecule stable against photooxidative damage. Food Res. Int. 2009, 42, 298-306. [CrossRef]

357. Ito, Y.; Kwon, O.H.; Ueda, M.; Tanaka, A.; Imanishi, Y. Gene-Engineered Hydrophobilization to Alter the Bactericidal Activity of Lysozyme. J. Bioact. Compat. Polym. 2000, 15, 376-395. [CrossRef]

358. Muszanska, A.K.; Busscher, H.J.; Herrmann, A.; van der Mei, H.C.; Norde, W. Pluronic-lysozyme conjugates as anti-adhesive and antibacterial bifunctional polymers for surface coating. Biomaterials 2011, 32, 6333-6341. [CrossRef]

359. Liu, Y.; Zhang, L.; Zhang, L.; Dong, Y. Human Lysozyme Modified by Cinnamaldehyde Coupling, and Modification Method and Application as Antibacterial Agent in Inhibiting Gram-Negative Bacteria. Patent No. CN112159802, 1 January 2021.

360. Liu, J.; Wang, N.; Liu, Y.; Jin, Y.; Ma, M. The antimicrobial spectrum of lysozyme broadened by reductive modification. Poult. Sci. 2018, 97, 3992-3999. [CrossRef] [PubMed]

361. Bogaerts, A.; Pankaj, A. Oxidized Lysozyme. Patent No. WO2020099556, 22 May 2020.

362. Cegielska-Radziejewska, R.; Lesnierowski, G.; Szablewski, T.; Kijowski, J. Physico-chemical properties and antibacterial activity of modified egg white-lysozyme. Eur. Food Res. Technol. 2010, 231, 959-964. [CrossRef]

363. González, R.; Mendive-Tapia, L.; Pastrian, M.B.; Albericio, F.; Lavilla, R.; Cascone, O.; Iannucci, N.B. Enhanced antimicrobial activity of a peptide derived from human lysozyme by arylation of its tryptophan residues. J. Pept. Sci. 2016, 22, 123-128. [CrossRef] [PubMed]

364. Yang, T.; Leśnierowski, G. Changes in selected physicochemical properties of lysozyme modified with a new method using microwave field and oxidation. PLoS ONE 2019, 14, e213021. [CrossRef]

365. Yang, T.; Leśnierowski, G. Microwave Modification as an Excellent Way to Produce Unique Lysozyme with Potential for Food and Human Health. Foods 2021, 10, 1319. [CrossRef]

366. Wen, S.; Yao, D.; Liu, X.; Wang, F. A Novel Fluorescence Resonance Energy Transfer-Based High-Throughput Screening Method for Generation of Lysozyme with Improved Antimicrobial Activity against Escherichia coli Strains. J. Agric. Food Chem. 2019, 67, 12584-12589. [CrossRef] 
367. Sharma, T.; Dohare, N.; Kumari, M.; Singh, U.K.; Khan, A.B.; Borse, M.S.; Patel, R. Comparative effect of cationic gemini surfactant and its monomeric counterpart on the conformational stability and activity of lysozyme. RSC Adv. 2017, 7, 16763-16776. [CrossRef]

368. Diels, A.M.J.; de Taeye, J.; Michiels, C.W. Sensitisation of Escherichia coli to antibacterial peptides and enzymes by high-pressure homogenisation. Int. J. Food Microbiol. 2005, 105, 165-175. [CrossRef] [PubMed]

369. Nakimbugwe, D.; Masschalck, B.; Atanassova, M.; Zewdie-Bosüner, A.; Michiels, C.W. Comparison of bactericidal activity of six lysozymes at atmospheric pressure and under high hydrostatic pressure. Int. J. Food Microbiol. 2006, 108, 355-363. [CrossRef] [PubMed]

370. Lesnierowski, G.; Cegielska-Radziejewska, R.; Kijowski, J. Antibacterial activity of thermally modified lysozyme. Electron. J. Pol. Agric. Univ. 2001, 4, 17.

371. Cegielska-Radziejewska, R.; Lesnierowski, G.; Kijowski, J. Antibacterial activity of hen egg white lysozyme modified by thermochemical technique. Eur. Food Res. Technol. 2009, 228, 841-845. [CrossRef]

372. Vilcacundo, R.; Méndez, P.; Reyes, W.; Romero, H.; Pinto, A.; Carrillo, W. Antibacterial Activity of Hen Egg White Lysozyme Denatured by Thermal and Chemical Treatments. Sci. Pharm. 2018, 86, 48. [CrossRef] [PubMed]

373. Derde, M.; Nau, F.; Guérin-Dubiard, C.; Lechevalier, V.; Paboeuf, G.; Jan, S.; Baron, F.; Gautier, M.; Vié, V. Native and dry-heated lysozyme interactions with membrane lipid monolayers: Lipid packing modifications of a phospholipid mixture, model of the Escherichia coli cytoplasmic membrane. Biochim. Biophys. Acta 2015, 1848, 1065-1073. [CrossRef] [PubMed]

374. Díez-Martínez, R.; de Paz, H.D.; de Paz, H.; Bustamante, N.; García, E.; Menéndez, M.; García, P. Improving the lethal effect of cpl-7, a pneumococcal phage lysozyme with broad bactericidal activity, by inverting the net charge of its cell wall-binding module. Antimicrob. Agents Chemother. 2013, 57, 5355-5365. [CrossRef]

375. Teneback, C.C.; Scanlon, T.C.; Wargo, M.J.; Bement, J.L.; Griswold, K.E.; Leclair, L.W. Bioengineered lysozyme reduces bacterial burden and inflammation in a murine model of mucoid Pseudomonas aeruginosa lung infection. Antimicrob. Agents Chemother. 2013, 57, 5559-5564. [CrossRef] [PubMed]

376. Griswold, K.E.; Bement, J.L.; Teneback, C.C.; Scanlon, T.C.; Wargo, M.J.; Leclair, L.W. Bioengineered lysozyme in combination therapies for Pseudomonas aeruginosa lung infections. Bioengineered 2014, 5, 143-147. [CrossRef]

377. Gill, A.; Scanlon, T.C.; Osipovitch, D.C.; Madden, D.R.; Griswold, K.E. Crystal structure of a charge engineered human lysozyme having enhanced bactericidal activity. PLoS ONE 2011, 6, e16788. [CrossRef]

378. Osserman, E.F. Editorial: Lysozyme. N. Engl. J. Med. 1975, 292, 424-425. [CrossRef] [PubMed] 